Portland State University

PDXScholar

$1-1-2011$

\title{
Writing Her Way to Spiritual Perfection: The Diary of 1751 of Maria de Jesus Felipa
}

Stephanie Oliver

Portland State University

Follow this and additional works at: https://pdxscholar.library.pdx.edu/open_access_etds Let us know how access to this document benefits you.

\section{Recommended Citation}

Oliver, Stephanie, "Writing Her Way to Spiritual Perfection: The Diary of 1751 of Maria de Jesus Felipa" (2011). Dissertations and Theses. Paper 309.

https://doi.org/10.15760/etd.309

This Thesis is brought to you for free and open access. It has been accepted for inclusion in Dissertations and Theses by an authorized administrator of PDXScholar. Please contact us if we can make this document more accessible: pdxscholar@pdx.edu. 
Writing Her Way to Spiritual Perfection:

The Diary of 1751 of María de Jesús Felipa

by

Stephanie Oliver

A thesis submitted in partial fulfillment of the requirements for the degree of

Master of Arts

in

History

Thesis Committee:

Caroline Litzenberger, Chair

John Ott

DeLys Ostlund

Amanda Powell

Portland State University

(C)2011 


\begin{abstract}
Throughout the colonial period of Mexican history, cloistered nuns wrote spiritual journals at the request of their confessors. These documents were read and scrutinized, not only by the confessors, but also by others in the hierarchy of their Orders. They are important sources of study for historians in that they provide a window into the religious culture of the times and the spiritual mentality of their authors.

This thesis will examine one such record, discovered in a collection of volumes at the Historical Franciscan Archive of Michoacán in Celaya, Mexico. The diary covers eleven months of 1751 in the life of a Franciscan nun -- believed to be María de Jesús Felipa -- who kept such records over a period of more than twenty years.

María de Jesús Felipa was a visionary who experienced occasional ecstatic states. Through her contacts with the spiritual world, she pursued her own salvation and that of those most specifically in her charge: members of her own community -- the convent of San Juan de la Penitencia in Mexico City -- and the souls in purgatory. These encounters propelled her into different frames of time and space -- moving her into the past and the future, and transporting her to bucolic and horrific locations. Her diary ascribes meaning to these encounters by tying them to her life and her relationships within the convent. Her diary of 1751 also indicates that this spiritual activity and the records she kept brought her to the attention of the Inquisition.
\end{abstract}


This thesis argues that, because of its cohesiveness of thought and consistency of focus, the diary effectively casts its record keeper as author of her own life story. A close reading reveals the inner thoughts and perceptions of a distinct personality. Her firstperson account also reflects the character of Christianity, the impact of post-Tridentine reforms and difficulties in the governance of convents in eighteenth-century New Spain. Although always arduous and often unpleasant, writing provided Sor Maria with an opportunity to establish her integrity, exercise control, and justify her thoughts and actions as she pursued her vocation. Writing under the supervision of a confessor, María de Jesús Felipa, nevertheless, was her own person. In its organization and focus, her diary resolutely records a struggle for self-determination within the limits imposed by the monastic vows of obedience, chastity, poverty and enclosure. 


\section{ACKNOWLEDGEMENTS}

My heartfelt gratitude goes to my thesis advisor and friend, Caroline Litzenberger, who saw me through several terms of directed reading of material, much of which was as new to her as it was to me. She guided me to clarify my thinking, focus my arguments and to be a better historian and writer. I also thank Amanda Powell, who encouraged me to contact Asuncion Lavrin as I searched for a thesis topic. Amanda gave me initial help in paleography and guided me in transcription. Her course in mysticism provided a framework for better understanding of the religious expression of nuns in the Early Modern period. And finally, thanks to Asuncion Lavrin, "my virtual professor," who blazed the trail in the studies of conventual life in New Spain and continues to open new pathways of research for us all.

Understanding the cultural milieu in which María de Jesús Felipa kept her diary has been, and continues to be, a journey. The experience calls to mind the gulf between the medical establishment and the Laotian Hmong in Merced, California as portrayed in The Spirit Catches You and You Fall Down, by Anne Fadiman. Doctors faced seemingly insurmountable cultural difficulties when it came to treating an epileptic child who was seen as holy by her immigrant community. A person understood as gifted in one culture can appear sick or delusional in another. For this Protestant raised in the Lutheran tradition that God's sacrifice of his Son was a once and for all gift, my encounter with Sor María and the culture in which she lived was a leap into the unknown. 


\section{TABLE OF CONTENTS}

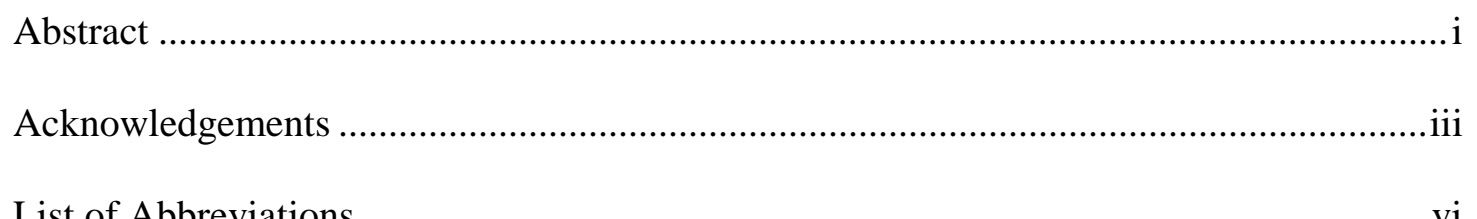

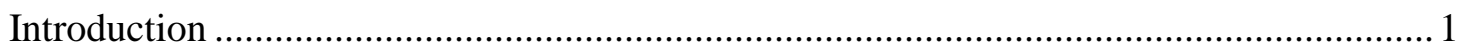

Chapter 1

Convent Culture in Colonial Mexico ........................................................................ 13

Chapter 2

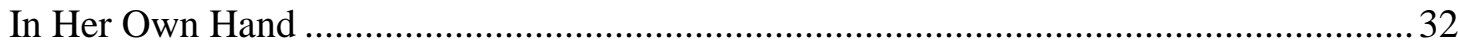

Chapter 3

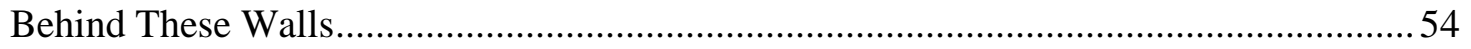

Chapter 4

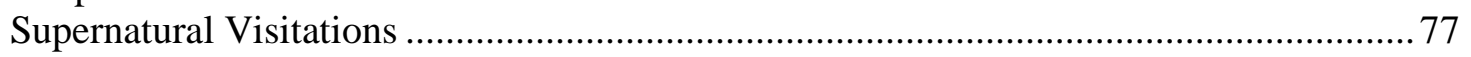

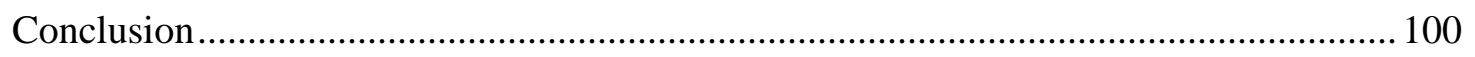

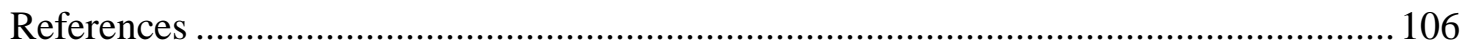

Appendices

A. Spanish Transcriptions ................................................................. 119

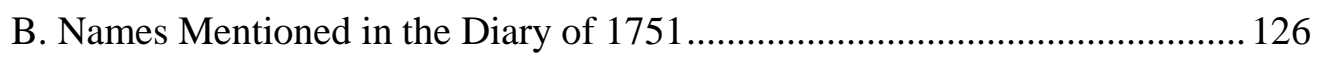




\section{LIST OF ABBREVIATIONS}

The following abbreviations are used in the footnotes.

AGI Archivo General de Indias, Seville (Spain)

AGN Archivo General de la Nación, Mexico

AHPFM Archivo Histórico de la Provincia Franciscana de Michoacán

AINAH, FF Archivo de Instituto Nacional de Antropología e Historia, Fondo

Franciscano

BN, FF Biblioteca nacional, Fondo Franciscano (Mexico)

BN Mexico Biblioteca nacional de Mexico

LC Library of Congress 


\section{INTRODUCTION}

Throughout the colonial period of Mexican history, cloistered nuns wrote spiritual journals in obedience to their confessors. These documents were read and scrutinized, not only by the confessors, but also by others in the hierarchy of their Orders. In many cases these records provided the basis for eulogies of exemplary nuns and for their biographies (vidas), which were redacted or written by others. The journals are important sources of study for historians. As noted by Asunción Lavrin, they provide a mirror to the mentality of the times and the psychology of their authors. ${ }^{1}$ Additionally, they broaden our historical understanding of the period in which they were written.

This thesis will examine one such record, discovered in a collection of volumes in the Franciscan Provincial Archive of Michoacán in Celaya, México. The diary covers eleven months of 1751 -- January through November -- in the life of Sor María de Jesús Felipa. ${ }^{2}$ It is the earliest of a number of volumes believed to be handwritten by this nun that scholars have discovered to date and thus is an appropriate point at which to break ground on her study. Initial research required transcription of 145 folios into a readable Spanish (i.e. providing punctuation, capitalization, and modernization of spelling) as well as translation into English of cited passages.

\footnotetext{
${ }^{1}$ Asunción Lavrin, Brides of Christ: Conventual Life in Colonial Mexico (Stanford: Stanford University Press, 2006), 322-3. Several works by Lavrin were consulted in preparation of this thesis. Future reference to Brides of Christ will be cited as "Lavrin." All others will include the title or partial title of the work cited.

${ }^{2}$ Lavrin refers to the journals left by the nun studied here as "diaries," a term this thesis will also use, although such a designation does not indicate that the records were kept on a daily basis. Rather they were turned over to a confessor were turned over to a confessor on a regular basis in the form of cuadernos -- or copybooks of several pages -- as if compiled, edited or written at a single setting.
} 
This thesis argues that, because of its cohesiveness of thought and consistency of focus, the diary effectively casts its record-keeper as author of her own life story. A close reading reveals the inner thoughts and perceptions of a distinct personality. Her firstperson account also reflects the character of Christianity, the impact of post-Tridentine reforms and difficulties in the governance of convents in eighteenth-century New Spain. Although always arduous and often unpleasant, writing provided Sor Maria with an opportunity to establish her integrity, exercise control, and justify her thoughts and actions as she pursued her vocation. As a record of events and the author's reflection on them, the diary reveals the psychological complexity of a real person expressed through the idiom of her times. She questions her faith and her vocation. She examines the issues of virtue and sinfulness; she deals with her shortcomings in managing herself and her relationships with others. However circuitous the route may appear to twenty-first century reckonings, the diary is a road map charting a path to the spiritual perfection that Sor María seeks. The volume is written with clarity and consistency of script and a cohesiveness of thought from page to page. A number of references to overdue installments, as well as the foreshadowing of events yet to come and reconsideration of events long past, serve to frame one of the tenets this thesis pursues: that the organization of the text itself reveals its author's search for integrity and purpose.

Written in a single hand, the diary of 1751 is numbered on its cover as volume twelve, appearing to be part of a much longer series of journals: twenty-one in all. It is the first of seven volumes housed in Celaya, covering the period of 1751 to 1760. The existence of eleven previous volumes cannot be verified at this time. The collection in Celaya contains records for the years 1751, 1752, 1753, 1755, 1757, 1759 and 1760 . The 
diary for 1758 is housed in the U.S. Library of Congress as one of a number of unrelated documents from eighteenth-century Mexico. ${ }^{3}$ How those archives came to house either collection is a mystery.

Asunción Lavrin brought the existence of these journals to light. She is the only one, to date, who has written about this nun, to whom she ascribed the name María de Jesús Felipa, based on entries in the diary she uncovered while researching the archives of the U.S. Library of Congress. ${ }^{4}$ Unfortunately, my only access to the volume of 1758 , a copy of which Lavrin has on microfilm, is through the large portions she cites in two articles written in Spanish and fragments she has made available to me. According to Lavrin, the diary of 1758 contains an explanation of Sor María's name and that of her convent, San Juan de la Penitencia. ${ }^{5}$ Little is known about this otherwise unknown nun.

${ }^{3}$ Volumes for 1754 and 1756 have not been uncovered in either location.

${ }^{4}$ In 2000, Asunción Lavrin published an article: "La escritura desde un mundo oculto: Espiritualidad y anonimidad en el convento de San Juan de la Penitencia," Estudios de Historia Novohispana 22 (2000): 49-75, which brought Sor María's journal of 1758 to scholarly attention. Since then, Lavrin has published two other works in which she analyzes Sor María's journal: Monjas y beatas and Brides of Christ. Shortly before publishing Brides of Christ, Lavrin discovered the seven additional volumes in the provincial Franciscan archive in Celaya, Lavrin, 335. Most recently, she and Rosalva Loreto López, a professor at the Autonomous University of Puebla, have gained permission from the Franciscan Provincial and the University of Puebla to publish jointly a transcription of the volumes held in the Celaya archive with commentary provided by the two editors. (See bibliography for full references.) Amanda Powell, University of Oregon instructor who pioneered scholarship on another Mexican nun, María de San José Palacios (1656-1719), suggested contacting Lavrin about women's writings of the period. Lavrin recommended María de Jesús Felipa and encouraged researching one of the diaries. She facilitated contact with the archive in Celaya. Both she and Powell have been generous in their advice since.

${ }^{5}$ In Brides of Christ, Lavrin writes that the identification of María de Jesús Felipa "was only possible because in several instances she explained the meaning of her name and her convent." See Lavrin, Brides of Christ, 335. In February 1758 (fol. 5) Sor María writes: "I am Felipa de Jesús and this favor was given in baptism; later, my Godmother [the Virgin Mary] conferred her spotless name in that I might take part in the sorrows of Mary of Jesus and of my saint, Philip." Again, in June of that year, she writes: "I saw nothing but that the complaints of some souls penetrated my own, making it seem as if they called my name: María de Jesús Felipa." See Appendix A. (1). Appendix A contains the transcriptions of citations longer than four lines that appear in English in the body of the thesis. Shorter transciptions are provided on 
Her name does not appear in the roster of San Juan de la Penitencia in notarized records covering the period in which she wrote. ${ }^{6}$ Her diaries contain only a few references to other people. $^{7}$

In addition to this introduction, this thesis is comprised of four chapters: Convent Culture in Colonial Mexico (1) places the document in its historical setting; In Her Own Hand (2) focuses on the writing itself, its organization, content and style; Behind These Walls (3) analyzes textual content relating to life within the convent, most specifically a series of incidents involving "real" relationships; Supernatural Visitations (4) looks at the author's visionary experiences, placing it in the context of the tradition of Spanish mysticism. A conclusion, list of references and two appendices follow the four chapters. The first appendix provides original Spanish transcriptions of diary entries cited in English in this thesis; the second appendix gives the names of individuals specifically mentioned in the text.

The Council of Trent (1545-1563) established guidelines for the governance of female religious orders. It codified the rules of enclosure as well as a number of other tenets of early modern Catholicism, including an emphasis on communion and confession. ${ }^{8}$ Many scholars have looked to the three sessions of Trent as ushering in a

the pages on which they are cited. All transcriptions of the diary of 1751 from the handwritten to typewritten Spanish are mine.

${ }^{6}$ Lavrin, Monjas y beata, 126. A notarized document for the canonical elections of abbess and other convent officials of San Juan de la Penitencia in 1779 does not list Sor María as among nuns in residence. It is possible that she had died by that date. Further research of such records would require a trip to Mexico City.

${ }^{7}$ See Appendix B for names that appear in the diary.

${ }^{8}$ This thesis agrees with scholars in recent decades who have disputed monikers such as Counter Reformation and Catholic Reformation to describe organizational and theological movements within the 
"confessional" age. They point to an emphasis on personal piety, inspired by reformists such as Ignatius of Loyola and Teresa of Avila, which gave an enhanced role to both the parish and ordained priests. Journals such as those found in Celaya can be seen as an extension of confession and the confessional relationship. They are emblematic of a movement from the spoken to the written word which took place in the early modern period. The confessor is the absent party in a dialogue. Frequently addressed and often quoted, he becomes, as noted by Kathleen Myers, a third component in a "mystical triad" of God, the confessor and the nun. ${ }^{9}$ The entries in this diary frequently read like half of an on-going conversation. At times they border on debate with a paper tiger as the writer turns things over in her mind. The requirement that this nun keep such a record over twenty-one years argues for a kind of pre-Freudian investigation into the state of her spiritual health by superiors. What motivated the requirement of such lengthy and laborious recordkeeping? Without the discovery of other documents -- the name of her confessor, correspondence about her and her journals -- one can only surmise that the journals were deemed important and that their author's spiritual experience justified extended scrutiny.

Roman Catholic Church during the sixteenth and seventeenth centuries as they coalesced around the Council of Trent. John W. O'Malley in Trent and All That: Renaming Catholicism in the Early Modern Era (Cambridge: Harvard University Press, 2000) provides the best argument for preferring early modern Catholicism. Good descriptions of the mix of canonical continuity and change, structural realignments and innovations including evangelization can be found in Robert Bireley, The Refashioning of Catholicism, 1450-1700: A Reassessment of the Counter Reformation (Washington, D.C.: The Catholic University Press, 1999); Elizabeth Makowski, Canon Law and the Cloistered Women. Periculoso and Its Commentators, 1289-1545 (Washington, D.C.: Catholic University Press, 1997) and Charles H. Lippy, Robert Choquette and Stafford Poole, Christianity Comes to the Americas 1492-1776 (New York, N.Y.: Paragon House, 1992).

${ }^{9}$ Kathleen A. Myers, "Fundadora, cronista y mística, Juana Palacios Berruecos/Madre María de San José (1656-1719)," in Monjas y beatas. La escritura femenina en la espiritualidad barroca novohispana. Siglos XVII y XVIII, ed. Asunción Lavrin and Rosalva Loreto López (Puebla: Universidad de las Américas, Archivo General de la Nación, 2002), 67. 
Spiritual diaries are among the many forms of convent writing now being researched by scholars of colonial Mexico -- known as New Spain during the nearly 300 years of Spanish rule. Nuns in this period kept many records. While not all nuns were ordered by their confessors to keep spiritual diaries, many in the seventeenth and eighteenth centuries were, and this thesis places the journal of 1751 within the context of other such writing. Not all are readily accessible in complete form, but a number of historians and literary scholars in recent years have made passages from their texts available in both Spanish and English. Mexican visionaries who kept journals - and whose work will be referred to in this thesis -- are inheritors of the spiritual legacy of Teresa of Avila and the seventeenth-century mystical tradition from Spain. Among them are Madre María Magdalena Lorravaquio, Madre María de San José Palacios, Sor Sebastiana Josefa de la Santísima Trinidad, Sor María Marcela Soria, and Sor María Anna Agueda de San Ignacio.

How unique to the diaries of María de Jesús Felipa is the literary style of her entries? How common is the intensity of her interior life and her conversations with her spiritual supporters and tempters? And, beyond that, to what extent can we see the diaries as a reflection of the character of Christianity in New Spain in the eighteenth century? More specifically, how do they mirror:

- the mission and practices of the cloistered nun;

- the relationship between the spiritual and temporal worlds;

- the impact of post-Tridentine doctrines and practices on

\author{
Catholicism in New Spain;
}


- $\quad$ the facility of women to interiorize and access the spiritual

through visions and the importance this visionary experience

held for the colonial Church in Mexico;

- the characteristics of "baroque piety" or sensibility as it took

root in the New World?

The research of a number of scholars is pertinent to this study. Josefina Muriel wrote the "bible" on colonial convents. ${ }^{10}$ Lavrin, who wrote her doctoral dissertation on colonial convents, is the undisputed expert in the field in English. As her attention shifted from female religious to colonial women in general, Lavrin became a guiding light in the field of gender studies in colonial Mexico. Her research on topics ranging from economic history to female and masculine sexuality in general has resulted in some 90 articles and chapters in books dating from 1970. I have also consulted work by Rosalva Loreto López. Loreto has written extensively on nuns and nunneries, most specifically on La Concepción and other convents in Puebla. She is Lavrin's partner in pioneering research and in the publication of María de Jesús Felipa's journals. ${ }^{11}$ Electa Arenal and Stacey Schlau wrote the first important work in English which cited extensively from the writings of colonial nuns. Since then, the number of historians and researchers in gender, cultural and literary studies has proliferated. Among the scholars who have translated the

\footnotetext{
${ }^{10}$ For further information, see Josefina Muriel, Conventos de monjas en la Nueva España (México: Editorial Santiago, 1946); and Cultura femenina novohispana (Universidad Nacional Autónoma de México, 1982).

${ }^{11}$ Loreto has produced a number of articles in addition to the work included in the bibliography. Most are in Spanish. Her study of the writings of Francisca de la Natividad is perhaps most pertinent.
} 
writing of individual Mexican nuns during the colonial era and written about them extensively are Jennifer Eich, Ellen Gunnarsdottir, Kristine Ibsen, Kathleen Myers and Amanda Powell. ${ }^{12}$

The so-called "baroque spirituality" finds its heritage in medieval penitential piety, the saintly tradition of Spain and the ecclesiastical devotional guides developed as part of the reformist movements within Catholicism, the Council of Trent and the move to Christianize the New World. These humanist guides were widely distributed in Spain and are pertinent to the mentality and the formation of the nun. They formed part of the heritage Spanish clergy and lay persons brought to America. Recent research by medieval and early modern scholars has opened a window on the significance of the body, physical self-denial and the centrality of communion that also formed part of the expression of faith in baroque piety, particularly in the case of female religious. Scholars who have focused on the relationship between female visionaries and their confessors in Europe provide background for understanding the mystical traditions that took hold in New Spain. ${ }^{13}$

${ }^{12}$ For further information, see Electa Arenal and Stacy Schau, Untold Sisters: Hispanic Nuns in Their Own Works, trans. Amanda Powell (Albuquerque: University of New Mexico Press: 1989); Jennifer L. Eich, The Other Mexican Muse: Sor María Anna Agueda de San Ignacio, 1695-1756 (New Orleans: University Press of the South, 2004); Ellen Gunnarsdottir, Mexican Karismata: The Baroque Vocation of Francisca de los Angeles, 1674-1744 (Lincoln: University of Nebraska Press, 2004); Kristine Ibsen, Women's Spiritual Autobiography in Colonial Spanish America (Gainsville: University Press of Florida, 1999); and Kathleen A. Myers and Amanda Powell, A Wild Country Out in the Garden: The Spiritual Journals of a Colonial Mexican Nun (Bloomington: Indiana University Press, 1999).

${ }^{13}$ For guides to female deportment, see Luis de León, La perfecta casada [1534] (Mexico: Editorial Porrúa, 1970) and Juan Luis Vives, The Education of a Christian Woman: A Sixteenth-Century Manual [1538], ed. and trans. Charles Fantazzi (Chicago: University of Chicago Press, 2000). For an understanding of the embodiment of spirituality among medieval religious, see Caroline Walker Bynum, Holy Feast and Holy Fast (Berkeley: University of California Press, 1982) and Fragmentation and Redemption: Essays on Gender and the Human Body in Medieval Religion (New York: Zone, 1991). The following works provide insights on the relationship between nuns and their confessors and the link 
In Brides of Christ, Lavrin asserts that the intimate spiritual writings that characterize these journals should be considered expressions of religious culture. They are valuable primary sources for understanding what she calls the "minds, values and attitudes" of those who authored them. ${ }^{14}$ Lavrin distinguishes herself from literary critics, such as Arenal and Schlau, who have interpreted women's writing as an act of defiance, and from Jean Franco, who sees the overlay of "self-effacement" and "irrationality of faith" as ultimately disempowering. ${ }^{15}$ However, like many other female historians in the field, she is an exemplar of the gender studies approach to history. She demonstrates a tendency in her commentary about these writings to emphasize a strategic power play between confessor and author. ${ }^{16}$

This thesis puts the writer on a prominent platform and approaches the act of writing as an endeavor that Sor María embraced as integral to her spiritual journey. Lavrin has written that the visionary's authority resides in her ability to experience a reality beyond the physical world. Certainly, Sor María's many encounters with visitors from the spiritual world are important. It is likely they were carefully scrutinized by her superiors. However, the nun's authority also resides in the text -- its organization,

between confession and spiritual writings: Frances Beer, Women and Mystical Experience in the Middle Ages (Woodbridge: The Boydell Press, 1993); Jodi Bilinkoff, Related Lives: Confessors and their Female Penitents, 1450-1750 (Ithaca: Cornell University Press, 2005); Alison Weber, Teresa of Avila and the Rhetoric of Femininity (Princeton: Princeton University Press, 1990).

${ }^{14}$ Lavrin, Brides of Christ, 313.

${ }^{15}$ Ibid., 323.

${ }^{16}$ A discussion of gender as it pertains to historical research, with references specifically to Jean Franco, Plotting Women: Gender and Representation in Mexico (New York: Columbia University Press, 1989); Joan Wallach Scott, "Gender: A Useful Category of Historical Analysis," in Gender and the Politics of History (New York: Columbia University Press, 1988), 28-50; and Laurie A. Finke, Feminist Theory, Women's Writing (Ithaca, NY: Cornell University Press, 1992), appears in Chapter 2. 
narrative voice and stylistic peculiarity. Sor María's own references to, or recognition of, gender or gender differences seems to be more cultural than determinative. Without denying the importance of gender as one form of historical analysis, this thesis both broadens and narrows the field of consideration, looking at the total historical religious context in which the diaries were produced (Chapter 1) as well as what has been labeled el barroco de Indias, a peculiar form of written and pious expression characteristic of colonial Spanish America (Chapter 2). ${ }^{17}$

Received wisdom from the historiography about nuns in colonial Mexico stresses the reader's ecclesiastical authority over the writer -- confessor over author in the production of these intimate spiritual writings. Because certain nuns were required to keep diaries, and because doing so was characterized (by them) as painful, gender scholarship has inflated the position of the priest in the equation. Lavrin opens the door to what she calls "hidden or acknowledged protagonism -- and the presentation of self within one's own community and time."18 Although she and others categorize these nuns as "protagonists," such references are often timidly espoused. This thesis exploits the active voice of the writer. It analyzes a series of techniques and episodes emblematic of the journal to demonstrate the personal authority of María de Jesús Felipa, looking at the frequency with which she requests a hearing, even to the point of exposure before the Holy Office. The three chapters focusing on the form and content of the diary look for patterns in its presentation, the frequency and types of subject matter that are included in the diary (Chapter 2) and how these compare with the journals of other visionary writers.

\footnotetext{
${ }^{17}$ Kathleen Ross, The Baroque Narrative of Carlos de Sigüenza y Góngora: A New World Paradise (Cambridge: Cambridge University Press, 1993), 4.

${ }^{18}$ Lavrin, Brides of Christ, 323.
} 
At one point in her narrative, Sor María writes that she was counseled by a friar, whom she refers to as the M.R.Pe. cura (Most Reverend father chaplain), to include "everything" in her writing. What is everything? To what subjects and events does she return again and again? In what way and to what end are they developed? Are there common threads in the way in which visions are presented, tropes are used, rhetorical devices employed? (Chapter 4)

Textual evidence indicates that Sor María edited her monthly installments before turning them over to her confessor. She provided him with a clean copy, always beginning on a right-hand page, ending exactly at the bottom of the left, occasionally inserting a date or reference to a saint's day to provide a context for the flow of thematic considerations. ${ }^{19}$ Though chapters are designated by month, this "historical" narrative is not strictly chronological. Chapters 3 and 4 present remembered events in "real" and "spiritual" time -- conversations with specific individuals in the monastery (3) as well as with her guardian angels, a number of saints, God the Father, Jesus Christ and the demons who bedevil her (4). Here, the content overrides the form and raises broader questions of historical theory. What is the relation between narrative discourse and historical representation in the diary? ${ }^{20}$ And how does that relate to the society in which

${ }^{19}$ A second party has censored entries throughout the diary. Names and titles often are obliterated, most consistently in reference to penitential practices involving Sor María and another sister, likely the abbess of the monastery, referred to as mi Madre (my Mother).

${ }^{20}$ Among the sources consulted on historical analysis are Hayden White, The Content of the Form: Narrative Discourse and Historical Representation (Baltimore: John Hopkins University Press, 1987); Michel de Certeau, The Writing of History (New York: Columbia University Press, 1988); José Antonio Maravall, Culture of the Baroque, trans. Terry Cochran (Minneapolis: University of Minnesota Press, 1986) and Laurie A. Finke, Feminist Theory, Women's Writing (Ithaca, NY: Cornell University Press, 1992). 
this text appears? These questions are considered in the chapters which analyze the diary, and reconsidered in the conclusion. 


\section{CHAPTER ONE}

\section{Convent Culture in Colonial Mexico}

Convents were established early in the history of colonial Mexico and formed an important part of the cultural and economic life of urban society throughout nearly three hundred years of Spanish rule, taking on their own special character that both challenged and helped define New World spirituality. Spanish women were not members of the military party that invaded Mexico in 1519. With the Catholic faith at the forefront, soldiers hoisted banners bearing the image of the Virgin Mary. Pagan temples and images were destroyed and replaced with crucifixes and saintly iconography. Hernán Cortés recognized early that interpretation of the faith should be put in the hands of professionals -- a petition he put to Charles $\mathrm{V} .{ }^{21}$ Friars were soon to arrive and dispatched to separate regions to evangelize the native peoples: Franciscans in 1524, Dominicans in 1526, and Augustinians in $1533 .^{22}$

Once the conquest was secured, "Old World" women began arriving in New Spain in greater and greater numbers turning settlements into colonies. Crown and Church were in agreement that bringing wives and marriageable daughters would civilize the territory and introduce peninsular values to the New World. With them came servants and unattached women who had nothing to lose. According to Susan Migden Socolow, wives, daughters and nieces of the conquistadors began arriving in New Spain as early as 1521. By the end of the century, the arrival of Spanish women throughout the colonies

${ }^{21}$ Hernán Cortés, Cartas de relación (Mexico: Editorial Porrúa, 1979), 203; as cited in Louise M. Burkhart, The Slippery Earth: Nahua-Christian Moral Dialogue in Sixteenth-Century Mexico (Tucson: University of Arizona, 1989), 16.

22 The Jesuits arrived later (1570), having first to resolve their difficulties with the Spanish Inquisition. See Diarmaid MacCulloch, The Reformation (New York: Penguin, 2005), 225, 300, 428. 
comprised 28 to 40 percent of the immigrants. Between 1500 and 1700, scholars estimate that 2,900 women arrived each year in America. ${ }^{23}$

With the arrival of Spanish women, convents soon were established. Nuns of the Conceptionist order disembarked in 1530, founding Nuestra Señora de la Concepción in Mexico City in 1540. In 1568, the first convent in Puebla, the colony's second largest city, was Santa Catalina: founded 37 years after that city was established. By the end of the sixteenth century, 20 convents had been founded in the Viceroyalty of New Spain, making the female orders an important part of the colonizing enterprise. ${ }^{24}$ Convents became centers of education, employment and refuge.

The movement to found convents continued throughout the colonial era, although scholars use different methods to calculate their numbers. In an appendix to Brides of Christ, Lavrin lists 58 convents established during the colonial era, the last being Nuestra Señora de Guadalupe in $1811 .^{25}$ Figures also vary in regard to populations within the convents. Estimates indicate that from fewer than 50 to more than a thousand women could be living in a convent at any one time. ${ }^{26}$ However, not all of those residing within the cloister were sisters. Thousands of women lived in convents as lay sisters, servants and slaves. A census of the Mexican convent of Santa Clara de Queretaro in the 1660s

${ }^{23}$ Susan Migden Socolow, The Women of Colonial Latin America (Cambridge: Cambridge University Press, 2000), 53-55.

\footnotetext{
${ }^{24}$ Myers and Powell, A Wild Country, 266.

${ }^{25}$ Ibid. The authors list 52 for approximately the same period.

${ }^{26}$ Ibid.
} 
counted 500 servants while the number of nuns was fewer than $100 .^{27}$ (Even novices could bring servants.) By anyone's count, a significant percentage of women, Spaniards and criollas, mestizas and mulatas as servants and slaves, lived within convents during the colonial era in New Spain. ${ }^{28}$

In the society at large, the ratio of religious to laity among whites was disproportionate. Ecclesiastical personnel in Mexico City in the mid-seventeenth century -- including about 1,000 nuns -- was more than 2,500, a healthy percentage of the criollo and peninsular population of that city. In Puebla, there were some 1,400, of whom 600 were nuns; in Vallodolid (Morelia), capital of Michoacán, the inquisitional records of 1654 indicate more ecclesiastical personnel than criollo and Spanish laity. ${ }^{29}$ Establishing a stronghold for the Christian faith was as important as the military effort in securing colonial control. The Spanish crown colonized the New World; the Spanish Church evangelized its native populations.

The clergy represented the temporal authority of the Crown and the spiritual authority of God. Spanish rule depended on the coordination of these two powers --

${ }^{27}$ BN, FF, Box 75, No 1255. La Reina Gobernadora al Presidente y Oidores de la Audiencia; as cited in Lavrin, 161.

${ }^{28}$ Criollo/a as it is used throughout this thesis, means a native-born resident of New Spain whose ancestry is Spanish. Although the distinction between Spaniard and Indian formed the basis of the colonial regime, an array of ethnic diversity soon flourished. The arrival of some 36,500 African-born slaves between 1521 and 1594 and the emergence of castas, mixed-race peoples, brought new (putative) categories of description such as mestizos, castizos, zambos, mulatos, etc. Their presence in the cities of New Spain created a plebian class. See R. Douglas Cope, The Limits of Racial Domination: Plebian Society in Colonial Mexico, 1660 to 1720. (Madison: University of Wisconsin Press, 1994) and J. I. Israel, Race, Class and Politics in Colonial Mexico: 1610-1670 (London: Oxford University Press, 1975).

${ }^{29}$ Fray Baltasar de Medica, Chronica de la santa provincial de San Diego de Mexico, de religiosos descalzos de N.S.P.S. Francisco en la Nueva España (Mexico, 1682), 238, 244; La Puebla de los Angeles en el siglo xvii, doc. ed. Mariano Cuevas (Mexico, 1945) 80-96; IAH 101 ant., 130; as cited in Israel, 48. 
Church and Crown -- to solidify control in the colonies. Royal patronage (patronato) granted by the pope to the Crowns of Spain and Portugal gave their kings power to approve -- in effect, appoint -- bishops and other important offices in return for evangelizing and tithing communicants, sending a percentage of what was gathered to Rome. The king, in effect, functioned as vicar and patron of the Church in New Spain. It was a national Church that functioned without papal intervention. Lay and monastic clergy were protected by charter (fuero eclesiástico): they could not be compelled to testify in civil court. They were protected as well by Church canon: they could not be subjected to imprisonment, censure or physical mistreatment by civil authorities. From a political perspective, the Church was meant to serve as an auxiliary to the Crown. ${ }^{30}$ It had power but not independence.

Establishing a simultaneously racially elite and orthodox culture was also an important role of the convent. Spaniards who immigrated to America brought with them a belief in the importance of bloodline. A history of expulsions of Jews and Muslims from Spain and on-going scrutiny of New Christians by the Inquisition in the homeland were reminders of the issue of limpieza de sangre (purity of blood). The gachupines -- newly arrived Spaniards-- were quick to create a system of castes, one which grew increasingly complex as the Europeans, Africans and Indians intermingled. "As victors," writes historian Patrick Carroll, "Spaniards thought themselves superior to the peoples they dominated. The trick was to convince others -- Africans, Indians and the growing number of half castes -- of the validity of this reasoning." Once established, subordinates "would

\footnotetext{
${ }^{30}$ Nancy M. Farriss, Crown and Clergy in Colonial Mexico, 1759-1821: The Crisis of Ecclesiastical Privilege (London: Athlone Press, 1968), 15.
} 
become their own oppressors and sustain (the) Iberians' hegemony." "31

Convents reflected this elitist ethic on two levels: the personal and the societal. To enter a religious order, a young woman needed to verify her European lineage. With few exceptions, black, indigenous, mulatto and mestiza (Spanish or criollo/a and Indian) women were prohibited from taking vows. ${ }^{32}$ Donadas, or "given" persons, often the product of an illegitimate and or mixed-race union, were sometimes recognized as lay sisters and like nuns they could not leave the convent. ${ }^{33}$ Frequently they were employed in low level jobs as were servants and slaves who arrived at the convent with their mistresses. $^{34}$

Keeping with the elitists, as well as spiritual mission of female monasticism in the viceroyalty, it was often a prominent widow with inherited wealth who donated property, endowed the convent, and entered it as the founding abbess, bringing female relatives or daughters and retinue with her. ${ }^{35}$ This was the case of the first Franciscan convent, Santa

${ }^{31}$ Patrick J. Carroll, Blacks in Colonial Veracruz: Race, Ethnicity and Regional Development (Austin: University of Texas, 1991), 32; as quoted in Cope, 4.

32 In 1724 Corpus Christi, a convent for indigenous women who could trace their heritages to native caciques (chieftans), was founded. Lavrin devotes a chapter to the creation and travails of Corpus Christi. Lavrin, "Indian Brides of Christ," Brides of Christ, 244-274. Elisa Sampson Vera Tudela notes a few instances prior to 1724 where indigenous women were permitted to take the veil. Sampson, "Fashioning A Cacique Nun," Gender and History 9 (1997): 191-206.

${ }^{33}$ Lavrin cites the case of Sor Leonor de los Ángeles, a woman of part-African ancestry who was taken by her likely white father to the convent of Santa Clara in Mexico City from Antequera, Oaxaca, and admitted under the mantle of spirituality. Stories of this holy woman's curative and prophetic powers in life and miracles after death served as "proof" of transformative nature of convent life, i.e., its ability to lift the lowly to a more exalted status. Lavrin, 33.

${ }^{34}$ In his discussion of race relations during the first half of the seventeenth century, Israel indicates that the prominent officials often possessed black slaves and even hired freed blacks as body-guards. As regards the Church, Israel writes: "The more select female convents of Mexico City and Puebla had more black girls to do the chores than they had nuns." Israel, 73.

${ }^{35}$ This follows a tradition long established in Europe in which women, usually wealthy, eschewed marriage and worldly goods for a life of privation and solitude. The Franciscan Order of St. Clare, of which 
Clara, established in New Spain in 1573. Its founders were a wealthy couple, Alonso

Sánchez and his wife Francisca Galván. After his death, Doña Francisca and her five

daughters took the habit of beatas and became the first residents of the hermitage, where

they received instruction from Franciscan priests on the Rule of St. Clare. ${ }^{36}$ The convent

where María de Jesús Felipa may have professed, San Juan de la Penitencia, was opened

on July 18, 1598, by four nuns from the convent of Santa Clara: María de San José, María

de San Juan, María de la Ascensión and Isabel de Santiago. ${ }^{37}$ This convent was

established without a benefactor, but later received a bequest of 60,000 pesos from a

young widow, Doña Juana de Villaseñor Lomelí. ${ }^{38}$ Fourteen more Franciscan convents

were to follow over the next three centuries. ${ }^{39}$ San Juan de la Penitencia followed the

María de Jesús Felipa was a professed, was founded by an early follower of St. Francis, Clara Sciffi of Assisi (1194-1253), who fled her home and the prospect of a socially advantageous marriage. Together with her younger sister and later joined by her mother, she established the order known commonly in English as the Poor Clares and wrote the Rule of St. Clare, a stricter version of the Rule of St. Benedict, which followed that of St. Francis. It dedicated its followers to a life of simplicity, work and prayer. Katharina M. Wilson and Nadia Margolis, Women in the Middle Ages: an Encyclopedia (Westport, Conn.: Greenwood Press, 2004).

36 Muriel, 142.

${ }^{37}$ Ibid., 168. San Juan de la Penitencia was unique among the convents in Mexico City. It was sited in an area populated by Indians, who granted use of the ground for the church and convent and provided the manpower in the construction with the stipulation that community residents would receive free burial when they died. Further research may reveal if the founders had a special commitment to poverty and whether there were obstacles raised to the foundation with no endowment. At any rate, this particular convent was poorly endowed and we shall see one instance in Sor María's journal of 1751, where she wrote a letter requesting help to reduce the cloister's debts. Chapter 3.

${ }^{38}$ Ibid., 170-71.

${ }^{39}$ Franciscan convents and their founding dates are as follows: Santa Clara, 1573, Mexico City; San Juan de la Penitencia, 1598, Mexico City; Santa Isabel, 1601, Mexico City; Santa Clara, 1607, Puebla; Santa Clara de Jesús, 1607, Queretaro; Santa Clara, 1617-18,Villa de Carrión-Atlixco; San Felipe de Jesús, 1666 (Capuchin), Mexico City; Santa Ana, 1704 (Capuchin), Puebla; Corpus Christi, 1724, Mexico City; Nuestra Señora de Cosamaloapán, 1737, Valladolid; San José, 1744, Antequera de Oaxaca; Señor San José, 1756 (Capuchin), Santa María de los Lagos; La Purísima Concepción y San Ignacio de Loyola, 1761 (Capuchin), Guadalajara; Nuestra Señora de los Ángeles, 1767-68, Antequera de Oaxaca; La Purísima y San Francisco, 1767 (Capuchin), Salvatierra; Nuestra Señora de Guadalupe, 1780 (Capuchin) Mexico City (Villa de Guadalupe); as listed in Lavrin, Appendix, 359-61. 
Rule of the Urbanist Clarisses (calzadas or calced), which did not demand extreme poverty -- the nuns could own property and maintain private funds -- or other rigors of the Capuchin Order.

Beyond the personal spiritual and material benefits it brought to its benefactors, establishing a convent through the donation of property or funds further legitimized a city's reigning culture. Founding a convent implanted a sacred space in an alien environment. These spiritual centers also added luster to the community's status. Wealthy patrons joined hands with ecclesiastical and civil authorities to bring the creation of these convents to fruition. ${ }^{40}$ Benefactors turned over property, donated money for buildings and paid dowries for needier novices in return for prayers and respect both within the convent and the community. ${ }^{41}$

In the case of highly endowed convents, such transactions and records could be complex. The convent of Santa Clara in Queretaro was an example where the capital endowments and estates brought by daughters and widows of prosperous families inflated the convent budget and turned the institution into a financial powerhouse. The buildings housing Santa Clara reputedly occupied more than four city blocks. "Its walls contained a bustling town of streets, gardens and public fountains," writes Ellen Gunnarsdottir, "[with] over sixty individual 'cells' large enough to house the nuns and their company

${ }^{40}$ To found a convent, patrons needed approvals by local, regional and imperial hierarchies, by the regional bishop and viceroy, by the pope and king. The Council of the Indies, which governed most aspects of life in the colonies, was also involved. Myers and Powell, 267.

${ }^{41}$ Male administrators known as mayordomos collected incomes from debts and liens and the rents of real estate for diocesan convents. Convents managed their own financial and administrative affairs under the supervision of either the bishopric or their own Order. Lavrin describes the organizational pattern as a double circle where the inner circle was occupied by the female hierarchy, the outer one occupied by the male. Lavrin, 121. 
and ten chapels." 42 The cells, in which the nuns and their entourages lived, were valued between 800 and 3,000 pesos -- well beyond the price of a fine home in Queretaro. ${ }^{43}$

Not all prospective nuns came from wealthy families, but all needed to be able to attest to their Spanish pedigree, their virginity and their legitimacy. ${ }^{44}$ The canonically approved minimum age for their entry was fifteen. Girls under fifteen could live in some convents as potential candidates, protégées of a particular nun, or as pupils. ${ }^{45}$ But as soon as young women reached the age of profession, absent a vocation and the presentation of a dowry, they were required to leave. ${ }^{46}$ Of course, powerful patrons could bend the requirements through a variety of means, money and position being chief among them. ${ }^{47}$ Founding abbesses who brought property and female relatives with them could also bend the rules as to age, residency and dowry requirements.

${ }^{42}$ Gunnarsdottir, 31 .

${ }^{43}$ Ibid., 35 .

${ }^{44}$ Lavrin devotes two chapters to the process of entering the nunnery: "The Path to the Convent" and "The Novice Becomes a Nun." These outline the social status of the young girl, the inquiry into the candidate's suitability, her application, which tested her reading and writing abilities, the ceremonials surrounding her first and final professions, and the education aims and tests through her years in the novitiate. Lavrin, 48-80.

${ }^{45}$ References to one such protégée appears in Sor María's journal. See Chapter 3.

${ }^{46}$ Lavrin writes: "Many poor women, either relatives or protégées, stayed in the convent as companions of the nuns or as helpers and servants without ever professing. They were called 'niñas' despite the advanced age of many, a euphemism that protected their stay." Francisco Fabián y Fuero, Colección de providencias diocesana del Obispado de Puebla (Puebla: Imprenta del Real Seminario Palafoxiano, 1770), 84-90; AGI, Mexico, 2753, fol. 128v; as cited in Lavrin, 23.

${ }^{47}$ In 1669, patrons of Sor Juana Inés de la Cruz forged a legitimate birth document for her despite her being the hija natural (illegitimate daughter) of a Spanish military officer. Dorothy Schons, "Some Obscure Points in the Life of Sor Juana Inés de la Cruz, Modern Philology 24.2 (1926): 141-62, and Algunos parientes de sor Juana Inés de la Cruz (Mexico: Imprenta Mundial, 1935); as cited in Lavrin, 21. Archbishop Francisco Aguilar y Seijas (1682-98) successfully maneuvered the Carmelite nuns of San José in Mexico City into accepting the candidacy of Juana de Zuñiga y Toledo without a dowry. AGN, Templos y Conventos, Vol. 36; also cited in Larvin, 376. 
The amount paid in dowry varied with the convent but was substantial. Funding the ceremonies for the initial and final profession also was costly. Then there was the purchase of a cell for a nun entering one of the regular Orders, and the provision of a wardrobe -- all of which inflated the cost well beyond the initial dowry. ${ }^{48}$ Pious donors, nuns themselves and confraternities became patrons of worthy postulants who lacked sufficient funds. Girls applied to be either "black veiled" or "white veiled." The latter, also known as lay sisters, brought a smaller dowry and lacked voting rights within the cloister. Women helped other women to become both white- and black-veiled nuns. Wills made by novices at the time of profession demonstrate a preference to support other women and their own convents once their own needs were met. ${ }^{49}$

Novices making their final profession made a lifelong commitment to four vows that trace their origins to the earliest appearance of monastic life and evolved through the Middle Ages. The vows of poverty, chastity, obedience and enclosure received their final confirmation at the Council of Trent, $1545-63 .^{50}$ Taken in combination, the vows formed

${ }^{48}$ In the case of Sor María de Jesús Felipa there is some question as to how much on-going financial support she receives from family. See Chapter 3.

${ }^{49}$ Postulants were required to make a will before their final profession, thus renouncing all worldly possessions. Since under Spanish laws daughters inherited equally with sons, the investment made in a religious profession required an adjustment in the shares of other progeny. This could mean a lot or a little to the family in question, since an income for the nun after profession frequently was provided in the form of reservas. Lavrin records one case, Sor María de San Bernardo in 1764, whose will states that she disposed of 12,000 pesos to be either lent at interest or mortgaged on properties to yield a 5 percent interest for her own expenses. Lavrin writes that her father mortgaged a property and a house to provide for her. Lavrin, 73.

${ }^{50}$ Convents of nuns first appeared in the third century. The Council of Constantinople, in 681, created the Law of Celibacy for both nuns and priests and named the virtues of poverty, chastity, obedience and a life in common as earmarks of the monastic life. JoAnn McNamara, Sisters in Arms: Catholic Nuns Through Two Millennia (Cambridge: Harvard University Press, 1996). With Periculoso in 1298, Pope Boniface VIII established perpetual enclosure as a condition of the solemn vows of female religious though it was not consistently interpreted or enforced until the Council of Trent. Makowski, 1. 
a web of commitments intended to shield life in the convent from the world outside $(e l$ siglo) and create conditions for devotion and observance of law and ritual. Looked at individually, they reveal the daily complications that their interpretation presented to individuals and institutions in real-life settings.

Poverty, for example, became one of the main sticking points between the regular and reformed Orders. Strict adherence to this vow proved to be unenforceable. In theory, the vow was made by the individual nun as an imitation of Christ, who both in his preaching and his person made clear that the riches God offered were not of this world. In practice, the interpretation of the vow varied from Order to Order, from convent to convent. As already noted, a candidate deeded over all her inheritance of goods and property at the time of her final profession. In effect, her family could separate part of it for her maintenance during her life in the form of a reserva, in addition to providing her with staff (including slaves), furniture, a clothing allowance, and all the personal comforts she enjoyed before she professed. ${ }^{51}$

The vow of chastity stood for renunciation of all carnal pleasures. A nun's chosen profession required that she guard herself from all impurity. Controlling the senses, mastering all appetites and sheltering her eyes and ears required constant vigilance. Grilles, curtains within the convent, and veils as part of her apparel separated her from

\footnotetext{
${ }^{51}$ As part of the hierarchy's focus on poverty, sumptuary practice came under fire in the eighteenth century. In 1735, the Franciscan Provincial finally put an end to a controversy over ruffles in the sleeves of habits by nuns in the convent of Santa Clara, by threatening excommunication to any nun who used such adornments or spoke in their favor or their opposition. A letter to the abbess of Santa Clara de Queretaro, 28/IX/1735 INAH Archivo Franciscano, vol. 100, as quoted in Pilar Gonzalbo Aizpuru, Las mujeres en la Nueva España: Educación y vida cotidiana (México: El colegio de México, 1987), 241. The broader issue of attachments to worldly goods and relationships also comes into play in the enforcement of enclosure: the presence of married women and widows, niñas who slept in the same room as their mistress, servants with their children who come and go, bringing gossip and the latest fashions from the outside world.
} 
the dangers of visual contamination. Fasting moderated her addictions to certain tastes.

The use of cilicios (penitential tools) and acts of self-administered flagellation aided nuns in dominating the flesh. ${ }^{52}$ In addition, as Caroline Bynum has noted, medieval asceticism as practiced by women in Europe brought them closer to God, making their bodies "parallel to the consecrated wafer on the altar and the man on the cross." piety as practiced by nuns in New Spain, the body became a means by which the spiritual was expressed. Simultaneously a method that humbled the practitioner, the practice also worked as a means to exalt her, particularly in the eyes of others. ${ }^{54}$ The relationship of body and spirit was central to the penitential practices of María de Jesús Felipa. Getting it "right" -- manipulating the frequency and modulating the body/spirit relationship -- was, for her, a vocational preoccupation and provided a pathway to visionary experience. It was an issue over which she petitioned her confessor for control and disobeyed his orders. At one point, she even recommended he experiment with penitential practices she had found effective. ${ }^{55}$

${ }^{52}$ Cilicios were made of rope or metal and worn under habits against the bare skin. The cilicios of certain holy women were found to be permanently embedded in their flesh. Lavrin provides a discussion with a number of examples in Brides of Christ, Chapter 6, "Body, Soul and Death," 177-208.

${ }^{53}$ Bynum, Holy Feast and Holy Fast, 296; as quoted in Lavrin, 177.

54 Confessors seemed to be walking a fine line between counseling the moderation of excessive penitential practices and eulogizing those who submitted themselves to arduous denial and selfmortifications. See Susan Laningham, "Maladies up Her Sleeve? Clerical Interpretation of a Suffering Female Body in Counter-Reformation Spain," Early Modern Women: An Interdisciplinary Journal (2006): 69-97. See also Kristine Ibsen, "The Hiding Places of My Power: Sebastiana Josefa de la Santísima Trinidad and the Hagiographic Representation of the Body in Colonial Spanish America," Colonial Latin American Review (December 1998): 251-70, for a record of the practices of Sebastiana Josefa de la Santísima Trinidad, who lived in San Juan de la Penitencia and was a contemporary of María de Jesús Felipa.

55 See Chapter 3. 
In early modern Catholicism, chastity was linked with virginity and the modeling behavior of Mary, the mother of God. However, the vow of chastity and within it an understanding of virginity, went beyond the physical. As noted by Clarissa Atkinson, after the thirteenth century, hagiographers tended to interpret virginity (chastity) in moral and psychological terms. The wife, the mother and the unattached woman were each capable of preserving "true" virginity by a life characterized by purity and humility. ${ }^{56}$ Between the thirteenth and fifteenth centuries, certain female saints (and would-be saints) experienced the relationship between sanctity and sexuality in new ways. "Virginity," writes Atkinson, "was no longer a pre-requisite for sanctity." recorded among the female martyrs and saints in The Golden Legend, a compilation of saintly lives that was widely read during this period. ${ }^{58}$

Obedience, the third of a nun's four vows, was a necessary ingredient in achieving a purity of purpose if a nun were to be successful in her path to perfection. Turning over her life to God meant submitting unconditionally to the directions of those within the hierarchy of the convent and the Order under whose Rule she professed. Any command issued by a superior was to be followed without question or analysis.

Disobeying a superior put a nun on dangerous ground. She could dismiss a confessor who created problems for her. She could cast a vote or even "lobby" for an abbess whose guidance she found to her liking. But only if an order endangered a nun's life or was

${ }^{56}$ Clarissa Atkinson, "Precious Balsam in a Fragile Glass: The Ideology of Virginity in the Later Middle Ages," (Journal of Family History: Summer, 1983), 131-43; as cited in Makowski, 4.

${ }^{57}$ Atkinson, 135.

${ }^{58}$ Spiritualizing virginity was not a new concept. Indeed, St. Augustine, writing about the sack of Rome and the rape of Christian virgins by pagans, had written "purity is a virtue of the mind. . it is not lost when the body is violated." Atkinson, 135. 
contrary to the Rule of the Order could she refuse to carry it out. The Bible provided amply illustrations of the importance of obedience: both the Virgin Mary on learning she was to bear a son and Jesus as he hung on the cross relinquished their wills to that of God.

Curiously, it is the interpretation of obedience on both the administrative and personal levels that raised the most issues in conventual life in early modern New Spain. A controversy over the vida común (the communal life) is certainly the most extensive in which issues of obedience played a role. ${ }^{59}$ Lasting more than a decade -- from 1759 to 1772 - the renewal movement consisted in a top-down mandate supported by a united male ecclesiastical front for monastic reform of practices entailing use of facilities, personnel, sleeping and eating arrangements. The main object was to bring all convents into conformity with the observance and internal discipline of the discalced (barefoot) Orders. ${ }^{60}$

Difficulty with the observance of obedience on a personal level is reflected in the

\footnotetext{
${ }^{59}$ It is beyond the scope of this thesis to enter the thicket of issues surrounding the struggles over the vida común, which pitted against one another hierarchies of Church and Crown, regular Orders and secular clergy and, more importantly, in specific convents with their own internal and external chains of command. Suffice to say, that, in the judgment of this scholar, the perspective presented by Margaret Chowning in Rebellious Nuns makes the most sense. Chowning sees the "characters in this story, on both sides of the rebellion and, later, on both sides of the vida común issue, as motivated by a sincere desire to make the convent community work as a place of prayer and contemplation." Chowning, 13. For a general overview, see Lavrin, "The Struggle over Vida Común," Brides of Christ, 275-309. For an in-depth look at the debate over one convent, see Chowning, Rebellious Nuns. In Convent Life in Colonial Mexico Stephanie Kirk analyzes similar conflicts in the founding of La Purisima Concepción (1756) in San Miguel el Grande.

${ }^{60}$ Although a case can be made for it being an issue of gender confrontation in its simplest expression, clarity on observance and obedience within Orders and specific communities was not uniform. The controversy led to disagreements on whose orders to follow. Legal battles ensued. A document signed by the nuns of La Santísima Trinidad to the bishop of Puebla, in May 1773 expresses the legal issue head on: "What we have represented to the Real Audiencia has been the spirit of truth and straightforwardness, that we did not admit and did not sign vida común and we ask that under the law, we receive the freedom to pursue our legal suit so that we return to the system we found when we professed." (Italics are mine.) AGI, Mexico, 2753; as quoted and translated in Lavrin, 275.
} 
diary of María de Jesús Felipa. She repeatedly requests revisions of orders from her superiors, specifically in regard to frequency of communion, proper practice of confession and penitence, and scheduling completion of her journal manuscripts. Visits from her guardian angels contain frequent recommendations to obey her superiors "blindly." In at least one case, she admits to ignoring a mandate ${ }^{61}$ More importantly, her struggles with issues of confidentiality make clear that obedience was subject to interpretation. For Sor María, practicing obedience was filled with ambiguity. ${ }^{62}$

In their final profession, nuns freely committed to enclosure -- to spending the rest of their lives within the walls of the convent. ${ }^{63}$ Separating themselves from the cares of the world was tantamount to living in a separate time zone, making the pursuit of a life dedicated to prayer, contemplation, self-denial and daily chores possible. As a social symbol, enclosure stood for both protection and restriction. This universal Church law prohibited not only exit from but entrance into the monastic confines by unauthorized persons. ${ }^{64}$ The Council of Trent codified these principles as canon. ${ }^{65}$

${ }^{61}$ See Chapter 2.

${ }^{62}$ Chapter 3 discusses a challenge María de Jesús Felipa faces when her brother and benefactor Don Pedro asks her not to reveal to her confessor information Don Pedro has shared in confidence.

${ }^{63}$ The origins of enclosure can be traced to a universal law handed down by Pope Boniface VIII in 1298. Periculoso gave nuns -- in the words of canon scholar Makowski -- "a status separate not only from male religious and laywomen, but also from the growing number of quasi religious female communities competing for, and often winning the support of the pious." Makowski, 4.

${ }^{64}$ For a further elaboration on how canonical scholars developed the relationship between chastity and enclosure, see Makowski, 126. She confirms observations by Jane Schulenburg and others that initially claustration was to provide a safe haven in a violent era but became, in the fourteenth and fifteenth centuries, an end in itself, under which other values of religious life were increasingly subsumed.

${ }^{65}$ See Kirk, 5; McNamara, 490; and Myers and Powell, 327. Kirk credits Trent with ushering in a period of "masculinist reform" by heightening the importance of confession and communion which, in effect, made ordination a requirement for admission to the Church militant. McNamara supports such an observation but emphasizes the manner in which women continued to carve out roles in spreading the faith. According to Myers and Powell, enclosure also aided the hierarchy of the Church in the New World in the 
Separation from their families was a wrenching experience for novices, as recounted in their journals. But separation from the world was impossible, no matter how sought after or idealized. Servants and slaves brought news of the outside into the cloister; visits by families in the locutorio, though subject to censure, were occasions to be cherished and revisited mentally. The journal of María de Jesús Felipa records a visit by her brother Don Pedro as well as a number of exchanges of letters. Sor María returns to them more than once as if reviewing their significance. Additionally, her relationships with persons within the convent created challenges that can only be considered "worldly," in that negotiating them brings her face to face with all kinds of preoccupations that take her away from concentration on her mission as a nun. ${ }^{66}$

Life in the convent was ordered around personal and communal observances involving prayer, penitence, and specific, assigned tasks as well as the regular cycles of meals and sleep. The yearly schedule revolved around the liturgical cycle of religious observances, including feast days and visitations by dignitaries as well as the business requirements of running the convent, such as elections of officials and procurement of necessary supplies. The physical plant was defined by a series of spaces in which different activities were to take place: a portería (entrance) where business with the outside world took place; the locutorio (parlor), where visitors were received; and the coro (upper and lower choir), where nuns, obscured by a mesh curtain and grille, attended Mass, received communion and prayed. Sor María's diary contains frequent

oversight of its convents. "In monitoring and controlling the public's access to its elite nuns," Myers and Powell write, "Church leadership used them both to revitalize the Church with their living examples of heroic virtue and divine favor and also to reinforce its hierarchical message about Christians' need for ecclesiastical guidance."

\footnotetext{
${ }^{66}$ See Chapter 2 and Chapter 3.
} 
references both to the coro and the portería. She writes also about the confesorio. It is likely that she meets with her brother in the locutorio. Additional to these and other quasi-public spaces were the private cells -- in some cases, suites -- inhabited by nuns and their attendants. ${ }^{67}$

The daily schedule of convent life was organized around prayer. ${ }^{68}$ Even as a nun attended to her oficios (duties), she was expected to complete her tasks while performing mental prayer. Yearly festivities centered on observances of saints' days, official visits of dignitaries, both civil and religious, and high points in the liturgical year: Advent, Pentecost and Easter. How these events were celebrated could involve special visits by preachers and guests. They always involved special observances by the convent separate from the community at large. Visits by the bishop or archbishop would entail the employment of musicians and the preparation of an array of foods. If a visiting priest were to preach, these sermons were heard with an attentive ear and supplemented the ongoing education of the auditor. In the journal of María de Jesús Felipa, references to these special events bookmark the record of her year, providing one of the few guides to a chronological understanding of what was taking place and a window into the importance of these activities in her life and the life of the convent. ${ }^{69}$ The sermons delivered on these

\footnotetext{
${ }^{67}$ San Juan de la Penitencia was not a reformed convent; sleeping and eating quarters were not comunal. It is likely that Sor María's cell included sleeping and cooking quarters for staff. She makes a distinction between her retreat (retiro) and her cell (celda).

${ }^{68}$ A typical day could look like the one followed at the convent of Santa Mónica in Oaxaca: lauds at daybreak, prime at 7:00 a.m., terce at 9:00 a.m., sext at noon, nones at 3:00 p.m., vespers at 5:00 p.m. and compline at 8:00 p.m. Matins were said sometime between 9:00 and midnight. Myers and Powell, 27071. Lavrin provides a schedule for the Dominican convent of Santa María la Gracia in Guadalajara and for the schedule of daily prayers for the Conceptionist convents. Lavrin, 118-19.

${ }^{69}$ The very first entry for the year opens with a reference to the Feast of the Circumcision. A myriad of such references is further indication that convent life was "lived" in liturgical rather than worldly time.
} 
special occasions appear to have given her food for thought and may even have shaped the didactic tone of some of her entries. ${ }^{70}$

It is unlikely that nuns had any direct access through books to what could be considered theological education. The education of the novice was looked upon more as technical training, not intellectual preparation. ${ }^{71}$ The novice learned the Rule of the convent, the rituals of the Church and the practice of her vows. She was being seasoned to a life of observance and discipline. Though reading material was likely limited to what the novice brought with her from her family, all convents had libraries of one sort or another. Their holdings were spotty and depended on the wealth of the convent. ${ }^{72}$ A more profound practice of her profession was the purpose of a nun's study. ${ }^{73}$ Much of her learning came by way of oral instruction: the listening to texts during shared meals and break times, and to sermons by visiting dignitaries. ${ }^{74}$ Nuns became so familiar with the exposition of the lives, teachings and visions of the saints that preceded them that the

${ }^{70}$ See Chapter 3.

${ }^{71}$ Lavrin, 56-58.

${ }^{72}$ The journal contains only one oblique reference to María de Jesús Felipa reading something: "I would go around looking for some light and entertaining books, see if I could find anyone to play cards with -- all in an effort to divest myself of that tight band and inner torment." Anonymous [Sor María de Jesús Felipa], Cuaderno manuscrito anónimo, sin título, Archivo Histórico Provincial Franciscano de Michoacán (Celaya: sección manuscritos varios, 5.9), 109v. See Appendix A. (2). A reference in June to "la hermana Rosa" as among those who were "outstanding in their Church" may indicate that she had either read or been familiar with St. Rose of Lima, who was canonized in 1671. Ibid., 76. In the future, references to the diary of 1751 will be cited as AHPFM, Sor María de Jesús Felipa, Diary, (folio number).

${ }^{73}$ A museum at the former convent of Santa Monica brings together a literature collection from three colonial Puebla convents. It contains a number of copies of Madre Agreda's Mystica ciudad; works by María de la Antigua, Teresa of Avila, Augustine, Luis de León, the vidas of Rosa of Lima, Anthony of Padua and Bishop Palafox y Mendoza, Myers and Powell, 337.

${ }^{74}$ Although corroboration is not available, it is likely that, in at least two instances, long pedagogic expositions that appear in the Sor María's journal of 1751 directly reflect the content of sermons by visiting preachers. See Chapter 2. 
content, themes and language of those who wrote of their own experiences are a replay of their forebears. ${ }^{75}$ Language, images and even whole visions sometimes read as if a piece of tracing paper were placed over an earlier text.

A nun's oficios (duties) within the convent were directly related to her seniority. Black-veiled nuns elected their abbess to a three-year term. Then the election had to be approved by the hierarchy governing the convent. An inappropriate choice could be annulled by a bishop; a disobedient abbess (Mother Superior) or one who allowed a "scandal" to fester could be removed from office. ${ }^{76}$ Excitement over elections mounted prior to a vote; coalitions of support or resistance formed. ${ }^{77}$ Theoretically, an abbess`s word was law within the convent. She was the matriarch, ultimately shouldering all responsibility for not only the spiritual and social life of the convent, but for its governance. ${ }^{78}$ Other oficios within the convent were meted out by the abbess -- many of which were rotated among those who, through demonstrated skill and/or their maturity, were qualified to carry them out. ${ }^{79}$ In the diary of 1751, María de Jesús Felipa writes of

${ }^{75}$ Myers and Powell, 304.

${ }^{76}$ An accusation of fraud pitted a defeated abbess against a vicar in 1716 at the Franciscan convent of Santa Isabel, Mexico City. Nuns lined up on both sides in a battle that reached the civil authority of the Audiencia before it was resolved. Lavrin, 126-8.

${ }^{77}$ Sor María's journal of 1758 reveals pre-election politicking prior to the election of an abbess at that monastery. Anonymous [Sor María de Jesús Felipa], Diary of a Mexican Religious, Feb. - Dec. 1758, (U.S. Library of Congress, Washington D. C.: Manuscript Division MM59), fols. 115-37; as quoted in Lavrin, Monjas y Beatas, 147-52. Hereafter, the journal of 1758 will be cited as LC Sor María de Jesús Felipa, Diary, (folio number).

${ }^{78}$ The relationship between María de Jesús Felipa and the abbess of her convent, referred to consistently as mi M[adr]e (my Mother) is curious from the standpoint of "power." Sor María reports to the abbess, submits to physical discipline by her, but also counsels and comforts her. See Chapters 3 and 4.

${ }^{79}$ Lavrin lists a number of oficios, with particular emphasis on the fiscal operation of the convent. Some of the others are the portera or concierge; the tornera, who operates the revolving window through which merchandise enters the convent; the maestra de novicias, who teaches to novices; the maestra de mozas, who instructs the servants; and the enfermeras, who care for the sick. Lavrin, 131-37. 
her responsibilities for the coro, to which she held the keys, and her teaching the young girls from the community who received primary education at the convent and of the novices. Sor María wrote frequently about the impact her earthly responsibilities, her oficios, had on the pursuit of her spiritual vocation, which will be explored in Chapter 3 . In Chapter 2, this thesis explores the diary as a historical document, placing it within the context of conventual writing in general and spiritual journals in particular. 


\section{CHAPTER TWO}

\section{In Her Own Hand}

Many nuns in New Spain could and did write. In addition to keeping administrative accounts, the abbess of a convent -- and those to whom she turned over the responsibility -- regularly communicated in writing with people outside the convent, secular and religious alike. Some, because of their recognized intelligence and the richness of their inner spiritual lives, were ordered by the superiors in their Order or by their confessors or bishops to write about their experiences ${ }^{80}$ Hundreds of their formal and informal letters, as well as these biographical records and chronicles of foundations, are stored in provincial, municipal and national archives and libraries in Mexico and Seville. Many have found their way to the United States: to the U. S. Library of Congress and to academic institutions such as Brown University, the University of Texas (Austin) and Indiana University. ${ }^{81}$ Nuns who displayed a talent for creative writing composed poems, lyrics to accompany music, and plays to be performed within the cloister. Tracts for instruction of novices and devotions were also written, most of which remained in manuscript form, but some of which were redacted and published for use by other

${ }^{80}$ It is beyond the scope of this thesis to summarize the European heritage of the intimate spiritual writings of nuns, some of which date from the twelfth century. A number of books provided background for this study. Among them are the already cited Frances Beer, Women and Mystical Experience in the Middle Ages; Ronald E. Surtz, Writing Women in Late Medieval and Early Modern Spain: the Mothers of Saint Teresa of Avila (Philadephia: University of Pennsylvania Press, 1995); and Isabelle Poutrin, Le voile et la plume: autobiographie et sainteté féminine dans l'Espagne moderne (Madrid: Casa de Velázquez, 1995).

${ }^{81}$ Some archival finds direct the future work of scholars for years to come. The exhaustive work of Kathleen A. Myers and Amanda Powell on Madre María de San José (Palacios), founder of the Augustinian convent of Santa Monica en Oaxaca (1697), began with the discovery of twelve volumes of her vida in the John Carter Brown Library at Brown University. 
convents and the public at large. ${ }^{82}$

Using theater pieces composed within the convent for teaching purposes was a tradition brought from Spain. These light entertainments were read or even acted out -although prohibitions against nuns donning costumes and playing parts appear among written records of the time -- during hours of recreo, when nuns also sewed and repaired garments. La Virtud Agradecida (Grateful Virtue), an undated and anonymous work, follows this tradition. ${ }^{83}$ It was written for the Franciscan Capuchin convent of Mexico City to be performed on Christmas Eve. In the play allegorical persons -- Good Counsel, Suspicion, a Perturbed Soul and a Tormented Soul -- illuminate through their dialogue the perils of temptation and self-doubt, and the support of prayer and confession on the soul's path to perfection. An Indian, speaking pidgin Spanish, appears at the end with a pillow under his arm. Perplexed by the goings on, he seeks solace in sleep, thus providing a "comic" ending to the piece. ${ }^{84}$

Outstanding among those who produced didactic and devotional writings is Sor María Anna Agueda de San Ignacio (1695-1756), whose learning was widely recognized and honored within her own lifetime and whose treatises were printed under the patronage of the Archbishop of Puebla, Don Domingo Pantaleón Alvarez de Abreu. Selfeducated and dedicated to reading, Sor María Anna was a student of the Old and New

${ }^{82}$ The Franciscan provincial archive in Celaya, where I studied the 1751 manuscript, houses a number of prayers, poems and plays from the Convent of Santa Clara de Jesús in Queretaro.

${ }^{83}$ Based on a reference to Juan José Eguiara y Eguren (1696-1763), appointed Bishop of Yucatan in 1752, Lavrin indicates that the play was probably written in the eighteenth century. Lavrin, 328.

${ }^{84}$ Lavrin raises the issue of "cross-dressing" to depict the male characters: Good Counsel, Suspicion and the Indian. Were actors hired? Did the female actors don male apparel to portray male parts? See Lavrin, 440, footnote 75. 
Testaments and could read Latin. The guidelines she wrote for daily observance of the Dominican convent of Santa Rosa de Santa María in Puebla, which she founded, were printed in 1746. Equally devoted to Christ and Mary, her guides were published as "pocket books" for lay and clerical use. Her Leyes del Amor Divino que debe guardar la fiel, amante esposa de Christo (Laws of Divine Law to be observed by the Loyal and Loving Bride of Christ) outlines the ten laws that bind the nun to Christ. ${ }^{85}$

Life-writing is the category within which the spiritual diary of 1751 of Sor María de Jesús Felipa perhaps best fits. ${ }^{86}$ In Women's Spiritual Autobiography in Colonial Spanish America, Kristine Ibsen notes that dozens of biographies, memoirs and personal writings of religious women, mostly redacted by confessors from the subjects' own notes, were published in the seventeenth and eighteenth century. Asunción Lavrin and Josefina Muriel have identified some 121 books published in Mexico using women's lifewritings. ${ }^{87}$ Transcribed and edited by those close to them or their superiors, these records often ascribe heroic virtues to these women while narrating visionary and ascetic practices not found in male biographies of the same period. Characterizing these intensely personal memoires is not easy. They are filled with deep feelings, revealing both the self-doubts and strong sense of purpose of the authors, as well as stories of the worldly and spiritual experiences that comprised the convent and religious culture of their

\footnotetext{
${ }^{85}$ Lavrin sees organizational and spiritual similarities between this work and Fr. Luis de León's $L a$ perfecta casada, Cantar de los cantares, Poesías originals (Mexico: Editorial Porrúa, 1970), 11-80; as cited in Lavrin, 343.

${ }^{86}$ How to categorize the diary initially explored here will be taken up again in the conclusion.

${ }^{87}$ Ibsen, Women's Spiritual Autobiography, 11.
} 
times. $^{88}$

A prologue often accompanies such a work crediting a confessor or prelate as instigator of the writing project. No information has come to light as to whether the respective authors were already keeping notes on their experiences. It is possible that in some cases their confessors simply mandated a re-editing of notes or a more regularized form of record keeping. ${ }^{89}$ Records show that Teresa of Avila wrote the first version of her Vida in 1565, from notes and letters produced over a period of time. In the case of María de San José (1656-1719), it was the bishop of Puebla, Manuel Fernández de Santa Cruz who, upon learning from her confessor about the nun's visions, requested that she keep a record of these supernatural experiences and that she write the story of her life. Sor María Magdalena Lorravaquio wrote at the command of her two Jesuit confessors. Begun in 1590, her eighty-one-page manuscript was copied by a trained hand in 1650 with the permission of her nephew Francisco Lorravaquio, a priest. Her visions raised the interest of Inquisitors. No doubt their scrutiny played a part in the request that she give a full accounting of her life, her theological examination by the Holy Office and a description of her practices and visionary experiences. ${ }^{90}$

${ }^{88}$ Subcategories within the genre of these personal writings are beginning to develop as more and more manuscripts are discovered and researched. See Kathleen A. Myers, "Crossing Boundaries: Defining the Field of Female Religious Writing in Colonial Latin America," Colonial Latin American Review Vol. 9, No. 2 (2000), 151-65.

\footnotetext{
${ }^{89}$ The celebrated analysis by Alison Weber (and by others) of the various editions of Teresa of Avila's Libro de la Vida raises the question of initiative. Access to quills and papers was available to convent leadership and to nuns of independent means in Spain and in New Spain. See Weber, Teresa of Avila and the Rhetoric of Femininity. María de Jesús de Felipa certainly had access to these implements. She refers to letters she has written and writes that she burned previously written notes and paper as a form of penance. AHPFM, María de Jesús Felipa, Diary, 13; 82.

${ }^{90}$ The case of María de Jesús Felipa may have been similar, in that her visionary experiences provoked both interest and concern on the part of her superiors. Her diary of 1751 mentions the Santo
} 
One way to approach the journal of 1751 of María de Jesus Felipa is to cast it as a first draft from which a hagiography, biography or autobiography could have been constructed. But although the records of the above-mentioned nuns and other authors, which will be considered in this and the following two chapters, share characteristics with Sor María's journal, none as yet discovered appear to be part of twenty-one year series of monthly installments. With the exception of the biographical writings of María de San José discovered in the archives of Brown University, the records represent the largest collection of conventual personal writings uncovered in New Spain to date. ${ }^{91}$ Nor have other monthly records been discovered that were maintained and delivered on schedule throughout a given calendar year such as this. ${ }^{92}$

Looking at the distinguishing characteristics of the manuscript, a number of other aspects make it distinctive from convent writings by other nuns. The format is consistent from chapter to chapter. Each monthly installment begins on the right-hand side of the page headed by the abbreviations J. M. J. (Jesús, María and José) and addresses its reader with the same salutation: Sr. y Pe. mío (My Lord and Father). Each month ends at the

Oficio and el Santo Tribunal (Holy Office and Inquisitional Court) on several occasions. Sometimes she demonstrates fear, sometimes bravado at the thought of a more public reading of her writings. See AHPF, María de Jesús Felipa, Diary, 65, 88v, 100, 123v, 130.

${ }^{91}$ The volumes in the Celaya series vary in length and are, in some cases, incorrectly bound. Lavrin has digitalized copies of all seven of the volumes in the Celaya archive and had done a cursory review of subject matter and physical characteristics when I spoke with her in September 2010. The volume of 1751, which numbers 145 folios, is missing the month of December, the absence of which goes unaccounted for in the January entry of 1752 . Otherwise, all months are bound in order.

92 The sixty "letters" written by Sebastiana Josefa de la Santísima Trinidad to her confessors were dispatched over a period of eleven years. Often dashed off at night, they bear the marks of diary entries entered in real time. They were later copied by Franciscan friars, whose marginal notations cite her virtues. See Lavrin, "De su puño y letra: epístolas conventuales," Memoria del II Congreso Internacional del Monacato Femenino en el Imperio Español: Monasterios, beaterios, recogimientos y colegios (Mexico: Condumex, 1995), 43-59; Kristine Ibsen, "The Hiding Places of My Power," 251-70, and Ibsen, Women's Spiritual Autobiography, 85. 
bottom of the left-hand page between eight and 16 folios later. The journal of 1751 is replete with references to the completed cuadernos (copybooks) Sor María was required to turn over to her confessor. Just what is meant by the term "cuaderno" is unclear, since the chapters are of uneven lengths. Additionally, Sor María's deadlines appear to have been once a fortnight. ${ }^{93}$ This is shorter than a month's worth of commentary; yet the fluency from page to page is uninterrupted, making it likely that drafts were maintained. ${ }^{94}$

Also, the diary appears to be in its unexpurgated, original form. It contains no marginal notes; the only evidence of a "reader (s)" is the obliteration of names in a different ink and the absence of an entire month. ${ }^{95}$ Taken together, Sor María's complaints about deadlines, the uniformity of script from page to page and the irregularity in chapter lengths argue for an attempt by the journal's author to self-edit and form the content into an integrated piece of writing.

The visual effect of Sor María's prose creates problems for the modern eye. Reading through a month of Sor María's writing is akin to wandering through a corn

${ }^{93}$ In one instance, the diary indicates a one-week deadline for turning in a copybook. AHPFM, Sor María de Jesús Felipa, Diary, 88v.

${ }^{94}$ Sor María complains about the deadlines for turning in copybooks throughout the record. Entries like the following indicate a period of reflection and a process of editing must have taken place before installments were turned over. In the February diary, she writes: "So, in that I was so overwhelmed with copybooks and my heart was so filled with these mercies and upsets about which Your Reverence knew nothing, I wanted to quiet my reason and find some relief from the schedule that had been established, so that Your Reverence might agree to my turning in the overdue one [installment] when I turned it the current one [copybook]. You denied my request saying that it would not work since The Most Reverend Father Chaplain was who decided [the schedule] according to his wishes, and thus [you] shut the door to this recourse." Again in June, she refers to the combination of completing a past assignment, while completing a current one. "Given my work load, I was very happy not to be writing, because well God knows the sacrifice this [writing] is for me; and I felt that it was in my favor to leave the past in the past and just write about the present -- which is what I know about." Ibid., fol. 25. See Appendix A (3).

${ }^{95}$ Sor María's diary is an "autograph manuscript," which distinguishes it from many of the other spiritual records by nuns of the colonial era that have been uncovered. Many have been recopied or annotated by editors. 
maze. For one thing, though the handwriting mostly is legible, her sentences lack punctuation, her spelling is idiosyncratic and inconsistent, and separate utterances are joined by the repetitious use of connectives -- "and", "since", "but", "while", etc. This follows the tradition of writing of the period. Walter Ong, an expert on the transition from orality to literacy in language production, notes that such a construction creates an "additive" rather than a "subordinative" style with one passage after another lined up like toy soldiers marching single-file across a flat landscape. ${ }^{96}$

Amanda Powell, who has translated major portions of María de San José Palacio`s prose, provides some tools for decoding the writing style of early modern spiritual writing. In "Language and Style in the Translation," her insightful section on the prose translation of A Wild Country out in the Garden, she emphasizes the cultural context in which writing took place. The rhetorical style of the period "was oral even when written," Powell writes. ${ }^{97}$ Filled with digressive stories and didactic lessons, this "secondary orality" was chronologically inconsistent in its organizational structure. Sor María's diary, composed half a century after María de San José's, fits this profile. Sor María takes up, drops and returns to events, retelling whole episodes with varying emphases. ${ }^{98}$ Like María de San José's, her prose is given to paraphrase and repetition

${ }^{96}$ Walter Ong, Orality and Literacy: The Technologizing of the Word (New York: Routledge, 2002); as cited in Powell, A Wild Country, xxx.

${ }^{97}$ Myers and Powell, xxvii.

${ }^{98}$ Ibid., xxvii. The translator underscores the observation by Carole Slade that early modern nuns lived primarily in a "late-medieval culture of things heard and seen rather than of things read." Carole Slade, Saint Teresa of Avila, Author of a Heroic Life (Berkeley: University of California Press, 1995), 43. Indeed, Sor María de Jesús Felipa makes only one reference to reading in her journal of 1751. In September, she writes: "I looked for some humorous or amusing book to read, or played cards -- all in an effort to rid myself of that tight band and inner torment." AHPFM, María de Jesús Felipa, 109v. See Appendix A (2). 
with a narrative flow interrupted by exclamations and confused syntax. ${ }^{99}$

It would be tempting to ascribe much of the complexity created by Sor María's prose to a baroque "literary" style. ${ }^{100}$ Many, including Octavio Paz, José Lezama Lima and Severo Sarduy, have argued that when Spaniards transplanted this culture of the baroque to America, there flourished a literary hybrid unique to the New World. ${ }^{101}$ Paz writes: "[this] Spanish tree planted in American soil has become another, with greener leaves and more bitter sap." 102 This barroco de Indias was a writing style that privileged - among other things -- polyphony. Like a musical fugue, it repeated patterns, counterpoints, independent melodic lines. ${ }^{103}$ Such mixtures of harmonies, returns to

${ }^{99}$ Myers and Powell, A Wild Country, xxviii-xxxi. Powell reviews a number of language peculiarities that María de San José and Sor María de Jesús Felipa have in common. Among them are repetition of words having the same root but with different endings ("the delight that delighted"), copia: doubling and tripling of nouns, verbs and adjectives ("great resolve and firm determination", "war and conflict") -- Ong describes this as an oral trick that gives a speaker [and writer] time to think; clichés and formulaic phrases, ("a dark night," "a firm proposal.")

100 José Antonio Maravall presents a creditable case for understanding the Baroque in early modern Spain as a stylistic phenomenon inherent in all arenas of cultural life: economic, political, religious and artistic. Chapter 4 of this thesis focuses on Sor María's dialogues with otherworldly visitors. Her descriptions of these visions recall the florid images of baroque paintings and decorative detailing of baroque architecture. Maravall asserts that, while the Catholic renewal movement strengthened papal authority and expanded the spirituality of the Society of Jesus, it also established the Baroque as its emblematic art form. Maravall, Culture of the Baroque: Analysis of a Historic Structure, 8.

${ }^{101}$ José Lezama Lima has argued that a so-called barroco de Indias is the foundation of Spanish America literature. Lezama Lima, "La curiosidad barroca," in La expresión americana (Havana: Instituto Nacional de Cultura, 1957), 43-81; as cited in Ross, 4. Twentieth-century Cuban novelist Alejo Carpentier, credited with coining the expression "magical realism," argued that his literary generation of the "boom" reinvented the Baroque. Alexis Marquez Rodriguez, lo barroco y lo real maravilloso en la obra de Alejo Carpentier (Mexico: Siglo Veintiun Editores, S. A., 1984), 25-26.

${ }^{102}$ Octavio Paz, "Literatura de fundación," in Puertas al campo (Barcelona: Seix Barral, 1972), 15; as cited in Ross, 4.

${ }^{103}$ Kathleen Ross examines the work of seventeenth-century criollo intellectual Carlos de Sigüenza y Góngora (1645-1700) as emblematic of this ornate, yet heterogeneous, style. Siguienza y Góngora wrote Parayso Occidental, a chronicle of the founding of the Convent of Jesus María (1684), based on the memoires of that institution's founding mothers. "The American nature of this baroque prose," Ross writes -- using Parayso Occidental as a period example -- "rests not in its usage of conceits, 
themes, and repeated patterns were consciously employed by the greatest literary figure of colonial New Spain, Sor Juana Inés de la Cruz (1648-1695). Sor Juana was, as Lavrin writes, "not a rebel, a mystic, or a depressed self-deprecatory member of her community." She entered the convent in order to practice her craft and did so at her pleasure until her erudition (and her success in publishing) landed her in political trouble with the hierarchy of the Church. ${ }^{104}$

María de Jesús Felipa does not fit this highly literary profile. Though much of her writing displays many of the characteristics emphasized by Powell, her exploitation of language, except for a few descriptive passages, is rarely evident. She was not a woman of letters. Her intellectual reference points are few. Her journal includes no specific biblical citation, nor does it display a working knowledge of Latin. The only "source" she quotes by name, Madre Agreda, is for a saying the common-sense wisdom of which seems applicable to a sticky situation in which Sor María found herself. ${ }^{105}$ Rather than attribute the complexity of her prose to a conscious manipulation of a literary baroque style, it perhaps makes more sense to see it in the context of a broader cultural phenomenon, i.e., as an expression of baroque piety absorbed orally. When María de Jesús Felipa uses a circular construction to express an idea or

digressions and other standard tropes, but in the manipulation of previous histories of conquest through the employment of language borrowed from literature." Ross, 45.

${ }^{104}$ Lavrin, 344.

${ }^{105}$ In August 1751 Sor María writes, "Then I remembered a doctrine of Mother Agreda that my Lady [the Virgin Mary] told her: 'Don't ask from the supernatural what you can get by ordinary means.' " AHPFM, María de Jesús Felipa, Diary, 95. See Appendix A (4). This "doctrine" is either something that is so often quoted among the sisters that it is a truism or Sor María is quoting from the Mystica Ciudad de Dios by the Spanish nun, Sor Maria de Jesús de Agreda (1602-65). In either case, the reference appears twice more: Ibid., 96, 108. 
repeats an idea or word with slight alteration, it generates out of her spiritual sensibility. When Sor María's mood swings from expressions of faith to disillusion, she demonstrates the tension between binary opposites that are the mark of baroque religious prose. Highly charged language expresses the difference between these opposites: romantic, erotic, and lyrical descriptions are juxtaposed to the sentimental, melodramatic, and bloody. The two sources most prominently played out in Sor María's expression of baroque piety are drawn from the Old Testament book, The Song of Songs, and the New Testament story of Christ's Passion. ${ }^{106}$ The tender language that Sor María employs when describing her Spouse and their relationship is consistent throughout the diary. After one particularly bitter contretemps, Sor María writes: "I had just taken communion on the nineteenth and my heart felt spacious and wide. . . It was as if my soul was embodied in that sweet and loving spirit of my Beloved; and his Majesty and I were alone in the world." ${ }^{107}$ In contrast, reliving the Passion of Christ, his suffering and death on the cross is the centerpiece of Sor María's penitential practices. The Crucifixion, Christ's sacrifice on behalf of a sinful world, inspired and guided her devotional life. ${ }^{108}$ The language

\footnotetext{
${ }^{106}$ The Song of Songs had been interpreted since the Middle Ages as emblematic of the relationship between the human and the Divine. It was given, in the writings of the Spanish mystics' inspiring interpretations of the love between the soul and its Creator, best expressed by San Juan de la Cruz. It also became the model for describing the relationship between the bride and Christ. Lavrin references San Juan de la Cruz, Subida del Monte Carmelo. Noche oscura, Cántico espiritual Llama de amor viva (Mexico: Editorial Porrúa, 1984) for his lyrical and expository exploration of the process of mystical unión; cited in Brides of Christ, 90.

${ }^{107}$ AHPFM, María de Jesús Felipa, Diary, 99-99v. See Appendix A (5).

${ }^{108}$ See Chapter 3 of this thesis for the part Sor María's penitential practices play in her understanding of her vocation and how that colors her life among her sisters and her relationship to her superiors.
} 
employed in these passages is sentimental, the descriptions bloody and lurid.

A review of the record for April demonstrates how baroque piety informs the writing style of the diary, intermixing worldly and spiritual events in no comprehensibly chronological order. No hour, day or week references these reflections or occurrences. ${ }^{109}$ It is only after several pages, almost midway through the chapter, that Sor María moves into real time -- on Friday, she writes -- to focus on the incident that give order to the entire monthly entry. ${ }^{110}$ Leaving Mass, she encountered discord among fellow sisters who are discussing the poisoning of the stray dogs that hung about the service entrance of the monastery. ${ }^{111}$ Sor María managed to salvage a favorite puppy that she had been feeding, but the incident plunged her into doubt about her calling:

Because of the dogs, I couldn't take my eyes from the world; I wanted to leave this convent and this thought soothed the anxieties that I felt; because I thought it would be better to live among disorderly people like me in the world instead of where there are hearts so hard that they would do to people what they do to animals. ${ }^{112}$

Sor María writes how she had sent a note to her confessor recounting the incident and asked his permission to keep the dog -- a request he denied. The matter was temporarily resolved, at least to her mind, when she put the puppy under the care of one of the

${ }^{109}$ A summary of the topics and "events" are as follows: a description of how ill Sor María feels and how she makes light of it to others; a reflection on how her inertia interferes with her penitential practices; a lengthy, complex vision in which St. Augustine reassures her that her practices are sound and that her position vis a vis her confessor is correct; a visitation of demons that torment her verbally and physically; and, finally, a comforting visit from Christ.

110 "I remained in this state until Friday, so that when the Most Reverend Father Chaplain chanted the Mass, the inner joy grew in such a way I thought it impossible I had received such mercies."AHPFM, María de Jesús Felipa, Diary, 54. See Appendix A (6).

${ }^{111}$ This relates to an earlier altercation with the madre who minded the service entrance of the convent. Apparently, she had put out cheese rolled in ground glass to discourage the stray dogs that circulated at the door. Ibid., 54-54v.

${ }^{112}$ Ibid., 54v. See Appendix A (7). 
señoras of her cell. (This is not the only time Sor María will reflect on the incident of the little dog or on conflicts with her confessor over decisions she takes independent of his instruction.) $)^{113}$

Examining the volume in its entirety or a single chapter as we have here, the reader is struck with two insights. First, the author seems to be using the writing to better understand herself and her mission, independent of any mandate from her superior. The April entry can be read as a piece, but not necessarily as a record in time. Recollections of events and musings about vocation or her state of spiritual health are interrupted by supernatural visitations. Dialogues with demons and angels both challenge Sor María and restore her to her vocational path. Requests that are thwarted by her superiors are circumvented by alternate means. Integrity of thought holds the entry together, whatever the circuitousness of its stylistic presentation. The reader senses that it may have been written as a complete write-through, perhaps from notes, and then recopied for clarity and readability. ${ }^{114}$

Secondly, the diary's author is self-conscious about the writing enterprise itself, and not just in the stylistics of its organization. Throughout the diary, Sor María writes about writing. The connection between journaling and self-examination for purposes of illumination is never far from her thoughts. As she writes in her diary of 1758: "I have experienced that at the time of writing everything becomes serene and I have freedom to

${ }^{113}$ In June, she writes, "And I give the Lord special thanks for letting me be in touch with the lowly because I am inclined to love them; I can't hide my love. . . . [and] that is why I care for dogs -- for their loyalty and for having that quality [of humility].” Ibid., 72. See Appendix A. (8).

${ }^{114}$ The speechifying of Sor María's spiritual interlocutors is unusually lengthy and, if taken as an accurate re-creation, argues for a phenomenal memory, accurate note-taking or a vivid imagination. 
express my sorrows, and as I put them down, my soul discovers the light of what I am saying." 115 Additionally, the act of writing is therapeutic. In July 1751, she writes:

When, in obedience to Your Holiness, I took up the quill once more and as my soul experienced such joy in subjecting itself to that obedience, I felt as though my heart could reach heaven.... With support so gracious, I set myself to writing until there was no longer light to see. I had profited from these very good comforts and though my enemies did all they could to bedevil me, they always found me engaged. ${ }^{116}$

With quill in hand, she sometimes is able to stave off her demons.

Interestingly, however, these entries about writing raise questions. What was she writing when she writes about having written: an earlier version of the journal, a poem, a prayer, a letter? Where are these papers? Is her cell piled with manuscripts? On more than one occasion, she writes that papers she had written were burned in penance. Were these overdue or current diary entries? The journal provides no clues, yet it is awash with referents to writings -- a veritable Chinese puzzle of documents within documents, hidden from view.

María de Jesús Felipa was counseled over and over by her superiors to unburden herself in writing as completely and as honestly as she could. For whatever reason -- lack of time, physical or emotional inertia, confusion about what to include -- she malingered in completing her assignments. Thus, she felt strengthened when the Chaplain (Muy Reverendo Padre cura), seeing her in distress, took her head in his hands and ordered her

${ }^{115}$ LC, María de Jesús Felipa, Diary, August 1758, cited in translation in Lavrin, 310.

${ }^{116}$ AHPFM, María de Jesús Felipa, Diary, 83-83v. See Appendix A (9). 
not to stop writing, because bottling it up was of no spiritual benefit. ${ }^{117}$ A review of the diary of 1751, however, reveals that writing itself creates inner conflicts. For Sor María, memorializing her thoughts and her experiences in writing was anxiety-provoking. ${ }^{118}$ In October, she addresses her confessor directly:

As you did not stop coming to give me counsel and clarity about what I was writing, calming me and encouraging me to unburden myself of all that was going on, I grew faint-hearted, because, as you have said -- and well Your Reverence knows -- I left out a lot. I was useless because I was filled with fears and doubts about what I had consciously left out. . . . I would hear in my ear: 'Do not do this; do not do that and all that I said [wrote], with these voices going on, had me disturbed and brought calamity on my head, pretending before Your Reverence, because I didn't want you to know and said nothing. I confess that answer I gave: 'No. I have left nothing out. What I experience, I write. No, there is nothing more [was not true]; and Your Reverence told me: 'Well then, daughter, you are making light [of this] because you alone can reveal the travails you are undergoing. Without telling them, there is no relief.' 119

The relationship between Sor María and her unnamed confessor is complex, as illustrated by this entry. He is her superior, her confidant, her spiritual father. He represents her heavenly Father on earth, directing her on her path to perfection. Sor María keeps her monthly journal as part of her confessional responsibility. It is an extension of a tradition that reached its height during the sixteenth and seventeenth century in Europe and continued into the eighteenth in the New World, although the relationship between

117 “(It was) as if the Most Reverend Father Chaplain saw my confusions: He spoke, taking my head in his hand; he ordered me not to stop writing because it did neither of us any good, and the very contact of his hands with my head strengthened my soul greatly." Ibid., 50. See Appendix A (10).

${ }^{118}$ No single monthly entry is without reference to the writing enterprise. This thesis reviewed thirty such references, some short and in passing, others more extensive. The whole of July 1751 concerns the relationship between writing and penance. Ibid., 78-89v.

${ }^{119}$ Ibid., 124v-125. See Appendix A (11). 
life-writing and confession predates Tridentine reform. ${ }^{120}$ St. Augustine established the model for life writing as a confessional medium at the turn of the fifth century. ${ }^{121}$ (It is notable that one of the first visions recorded by Sor María is a dialogue with St.

Augustine. Readings from St. Augustine's Confession were likely part of the aural training given to novices; and professed nuns certainly listened regularly to such works during shared meals and recreación.)

By 1200, priests were composing full-length biographies of exemplary female penitents. The celebrated "partnership" between Catherine of Siena and her Dominican confessor Raymond of Capua enabled the saint to increase her charismatic reach. She preached charity and peace; he accompanied her on her travels, recording her life and work. With printing in the sixteenth century, these vidas were translated into the vernacular, mass produced in many editions and became popular reading in Spain. Teresa of Avila (1515-1582) recalled reading them as a child and being transported by what seemed like "adventure tales." She and her brother built a little cave behind their house where they played at being hermits in the desert. They imagined themselves martyrs for Christ, proselytizing among the Moors.

Teresa had a series of confessors throughout her career, not all of whom were of

${ }^{120}$ Making a regular oral confession dates as a practice from the time of the early Church. In the twelfth century oral confession became one of the seven sacraments. Briefly stated, confession involves the examination of conscience by the penitent, his or her formal acknowledgement of remorse or contrition, and the priest's bestowal of absolution and assignment of penance. The formal relationship between individual penitent and confessor priest became an integral part of the Catholic Reform movement with the rise in importance of the Society of Jesus. The Council of Trent regularized the frequency of confession by tying it to communion. The Council codified the relationship between confession and communion, by stating that in order to take communion "worthily," one should first confess. By 1400, the Church had recommended it take place once a week. Bilinkoff, Related Lives, 20.

${ }^{121}$ Augustine, Bishop of Hippo, Confessions, ed. William Watts and W.H. D. Rouse (New York: Macmillan, 1912). 
her intellectual caliber or sympathetic to her mission. She began Libro de la Vida with an acknowledgement of the confessor's role in writing her "life":

Although I would have much preferred to have clearly and very specifically written about my great sins and shabby life, my confessor commanded me and gave me plenty of leeway to write about the favors and kinds of prayer the Lord has granted me. ${ }^{122}$

It would be inaccurate to assume that the term "command" in the performance of these life-writings necessarily meant suspicion of deviance by authorities. Certainly, concern over orthodoxy was a factor in the hierarchy's making such requests. It would not be unreasonable to assume, however, that genuine interest in the special access that female religious had to the Divine through their visions was also a factor. Support and encouragement by admiring sponsors also guided these petitions. Whatever the circumstances, the writers primarily wrote to an audience of one, knowing that behind him were others, all male, all with greater authority than she.

Nuns who kept spiritual records mentioned often their desire for a compatible confessor: a kindred spirit, someone with whom they could establish a reciprocal relationship of advice giving and consolation. ${ }^{123}$ Teresa of Avila is the most famous example of a woman who complained of the ridicule and reproach nuns experienced from bad confessors. She was 60 in 1575 when she finally met Jerónimo Gracián, 30, and

\footnotetext{
122 Translation is mine. The opening words of the prologue are: "Quisiera yo, como me han mandado y dado larga licencia para que escriba el modo de oración y las mercedes que el Señor me ha hecho, me la dieran para que por muy menudo y con claridad dijera mis grandes pecados y ruin vida." Teresa de Jesús, Su Vida (Buenos Aires: Espasa-Calpe Argentina, S. A., 1951), 22.

${ }^{123}$ Bilinkoff, Related Lives, 77. Chapter 3 of the thesis explores Sor María's search for this kind of compatibility with her confessor.
} 
wrote enthusiastically about finding the "right" confessor. ${ }^{124}$ Spanish nun María Díaz was 60 and, in 1559, already renowned when she got a new confessor of 26, Jesuit Baltazar Alvarez. His biographer, Luis de la Puente, notes "this holy woman had good fortune in meeting Father Baltasar who helped her a great deal in her spiritual ascent.",125

The Council of Trent formally authorized a nun to replace an incompatible confessor with another. Though not always respected, this right was an early stickingpoint between the regular Order of Carmelites and the Discalced which Teresa founded. ${ }^{126}$ In New Spain, Madre María de San José suffered under the care of one confessor -- Juan Dionisio de Cárdenas -- who once commanded her to write for twentythree hours in succession. ${ }^{127}$ (He lasted a year.) Sor Juana Inés de la Cruz fired her Jesuit confessor Antonio Núñez. ${ }^{128}$

This thesis recognizes the importance of the confessor both in requiring a nun to keep a journal and in serving as its primary reader. Difficulties with confessors, as noted by Lavrin and others, often engaged these authors in a "dialogue of power." ${ }^{129}$ Feminist

${ }^{124}$ Ibid., 80-81.

${ }^{125}$ Luis de la Puente, Vida del Padre Baltasar Alvarez (Madrid, 1615), 39v; as cited in Bilinkoff, 81. See also Laningham, "Maladies up Her Sleeve," which traces the travails of María Vela, a sixteenthcentury Cistercian through a series of clerical confessors.

${ }^{126}$ Arenal and Schau provide ample background to the political infighting between regular and reformed Orders of the Carmelites in the aftermath of Teresa's death. Arenal and Schlau, Untold Sisters, 19-36.

${ }^{127}$ Katherine A. Myers, Neither Saints nor Sinners: Writing the Lives of Women in Spanish America (Oxford: Oxford University Press, 2003), 83.

${ }^{128}$ The letter Sor Juana sent dismissing Núñez was discovered in 1980. It was written in 1680, ten years before Sor Juana wrote La Respuesta, the autobiographical defense of her theological and secular writing. Electa Arenal and Amanda Powell, The Answer $=$ La respuesta (New York: The Feminist, City University of New York, 1994), 26.

${ }^{129}$ Lavrin, 337. 
literary analyst Jean Franco writes that, while life-writings under the profession of obedience helped authorize a form of knowledge that bypasses the authority of the confessor, they were used by the system to strengthen its patriarchal authority. ${ }^{130}$

Katherine Myers and Amanda Powell agree when they cite Franco's viewpoint that:

mystic expression only temporarily gave nuns temporary access to language that was strictly their own.... [The] Church patriarchy viewed woman's mystical knowledge as outside reason and order, and, therefore it reordered and adapted it. Franco points out that most of these Mexican women's writings were used by the Church for its own ends. ${ }^{131}$

The system has the last word; patriarchy rules. ${ }^{132}$ Much of the groundbreaking study by Arenal and Schlau rests on this basis as well. ${ }^{133}$

María de Jesús Felipa recognizes this when she writes: "Only God knows that the most distressing thing in this inner path is to deal with men, even saintly ones." ${ }^{134}$ But however many times Sor María addressed Vuestra Reverencia (Your Reverence) directly in the journal of 1751 examined here, she frequently steps back and speaks of him as if he

${ }^{130}$ Franco, Plotting Women, 15.

${ }^{131}$ Myers and Powell, 199.

${ }^{132}$ In her chapter on Sor Juana Inés de la Cruz, Franco laments that, although La Respuesta demonstrates the real power of the woman, in the end it is impossible for Sor Juana to separate personal love from the love of the body politic and the body politic from the recognition of authority. Underlying everything is a belief in essential benevolence of a hierarchical system [the Church, the State] as a human representation of divine power. Franco, 50-51.

${ }^{133}$ Kristine Ibsen notes that, although women who were asked to write their vidas were able to cast themselves as heroines of their own life stories, they were put in an ambiguous situation of defining themselves according to their culture's gender codes while simultaneously questioning the encoding. Like the authors of Untold Sisters, Ibsen cites French philosopher historian Michel Foucault's analysis of the confessional "discourse" as one of a relationship of power and resistence. Ibsen, Women's Spiritual Autobiography in Colonial Spanish America, 17.

${ }^{134}$ LC, María de Jesús Felipa, Diary, 121v.; as cited in Lavrin, 337. Yet earlier in that same journal, she also directly addressed her confessor: "I know that in obeying you, I obey God himself. Ibid., 109; as cited in Lavrin, 337. 
were a character in a drama in which she plays the starring role. ${ }^{135}$ Additionally, particularly in the record for September, which focuses on the part her diaries might play in censure of the convent's administrators, Sor María is without reservation in recording the confessor's unavailability and irascibility, while at the same time taking full responsibility for the content of her record. ${ }^{136}$ Such references call into question an overly gendered reading of these early modern spiritual writings. Focusing on the tension between penitent and confessor as a power relationship privileges the reader over the writer in the creation of these documents. Such an approach minimizes the agency of the author. Indeed, keeping a monthly journal, producing it over a number of years -- as was the case with María de Jesús Felipa -- was an involuntary act. But what happened in the process of the writing? Taking up a quill and putting it to paper transformed a recordkeeper into a narrator. Without rejecting the importance of the hierarchical structure within which María de Jesús Felipa operated, this thesis reframes analysis of her diary from the perspective of an author who defines the story and how it is told. It also recognizes the fact that its author saw a readership for the record of her experiences that went beyond her confessional relationship. She writes in January: "I can do no less than

${ }^{135}$ The words Vuestra Reverencia (Your Reverence) are so constant throughout the pages of the diary that it would be tedious to enumerate them. Clearly, Sor María's confessor is a major character in the "story" of her life. In some cases, Vuestra Reverencia is a polite address; in others, the words introduce discussion of a continued dialogue. In many cases, as in the following, the confessor appears more as a character in a narrative than an interlocutor: "I was burning with happiness, telling you that it was time to clarify in the copybooks what had occurred with Don Pedro. . . Your answer was to tell me: 'No, daughter. I came to talk to you about this; that is why I am here. We will go to into the confessional and speak at length.' . . . I felt not a shred of consolation and instead of comforting me, what you said distressed me even more and made me despair." AHPFM, María de Jesús Felipa, Diary, 107v-108. See Appendix A (12). As we will see later, the confessor's preference that conventual issues not be dealt with in writing, but rather in the confessional, strikes me as reminiscent of the modern-day CEO's fear of creating a paper trail.

${ }^{136}$ Two ítems of note in the September entry are her request for more regular confessional contact with him and her description of how, on one occasion, he abandoned her in the confessional in a fit of pique (salió muy colérico). AHPFM, María de Jesús Felipa, Diary, 104-117v. 
follow the light that puts me on the path because what I have been charged with is for posterity. . . because how many men and women reading this when the divine decree arrives, losing their fear, will be cheered and impassioned one to another.",137

Such a perspective also finds support from within the ranks of gender studies academics. Joan Wallach Scott is notable among those who have written thoughtfully about how the social category of gender fits within twentieth-century historical research principals. For Scott, gender is a cultural construct, a social category imposed on a "sexed" body. ${ }^{138}$ A recognized difference in gender has the same kind of importance as a factor in understanding relationships as do race, class and educational differences. Gender can be looked at from a descriptive or a causal perspective. Scott tends to see it both ways: as a constitutive element of social relations and as a primary way of signifying relationships of power. Gender studies scholars who pioneered research of early modern women's spiritual writings -- both historians and literary analysts -- have, like Scott, recognized this dual role. ${ }^{139}$ And there is no denying the presence of both attributes ina n examination of the diary of María de Jesús Felipa. She wrote under the

${ }^{137}$ Italics (mine) are added to indicate Sor María's empowerment. Ibid., 14-14v. See Appendix A (13).

${ }^{138}$ Scott, "Gender: A Useful Category of Historical Analysis,” 32.

139 Alison Weber contributed groundbreaking research in her application of rhetorical strategies, most specifically the psychological category of the "double-bind" theory, to the study of Teresa of Avila. See also Electa Arenal and Stacey Schlau, "Stratagems of the Strong, Stratagems of the Weak: Autobiographical Prose of the Seventeenth-Century Hispanic Convent Author(s)," Tulsa Studies in Women's Literature, Vol. 9, No. 1, Women Writing Autobiography (Spring 1990), 25-42. 
direction of a male hierarchy, but her gender is only one of a number of characteristics defining her identity. ${ }^{140}$

Gender studies scholar Laurie A. Finke perhaps serves as a bridge to the historical approach taken by this thesis. Finke proposes an alternative to looking at history as a record of power struggles, citing scientific as well as literary theorists to bolster her approach. ${ }^{141}$ Finke's perspective is congenial to a study of the record as produced by María de Jesús Felipa in that she starts with what she calls "the unresolved tension between what happened and narratives about it." ${ }^{142}$ In the case of Sor María's journal and, indeed, any historical record, we have no immediate access to the events prompting its creation. These events come to us through documents, yet the documents themselves are constructs. Facts become facts because they are embedded in a narrative, which is the product of the mind that creates the record. ${ }^{143}$ Looking at the journal of 1751 from a historiographical perspective comes down to recognizing the agency of its author: María

${ }^{140}$ In Untold Sisters, Arenal and Schlau credit the work of French philosophical and psychological scholars whose insights influence a genderized approach to early modern women's writings. Most important among them are Michel Foucault and Jacques Lacan. A summary discussion of this position is outlined in a section entitled "Sexuality, Language and Power." Arenal and Schlau, 11-12. For further reference see: Foucault, The History of Sexuality, vol. 1 (New York: Pantheon Books, 1978); Lacan, Ecrits: a selection (New York: Norton, 1977).

${ }^{141}$ Finke, Feminist Theory, 2, 6.

${ }^{142}$ For Finke, the experiences of female mystics destabilized patriarchal cultural practices in the medieval and early modern Church. She prefers to discuss gender as contributing to the complex information base from which "historic facts" are constructed. Finke develops her argument based on theories presented by Katherine Hayles, "Chaos as Orderly Disorder" New Literary History 20 (1989): 30522; and Michel de Certeau, La fábula mística (Siglos XVI-XVII), Mexico: Universidad Iberoamericana, 1993).

${ }^{143}$ According to Finke, Stephen Hawking says that scientists face the same dilemma of access as do historians. Hawking describes quantum mechanics as essentially a theory of "what we do not know and cannot predict." Stephen Hawking, "Is the End in Sight for Theoretical Physics?" In John Buslough, Stephen Hawking's Universe: An Introduction to the Most Remarkable Scientists in Our Time, 1985; rpt. New York: Avon Books, 1989, 138, as cited in Finke, 7. 
de Jesús Felipa. It is she who defines the territory, the "facts" to include -- the story to be told. History writing shares with fiction writing the same tools for producing meaning. ${ }^{144}$ Sor María decides what constitutes a fact -- be it descriptive, anecdotal or dialogic -- for the purposes of creating her narrative.

Two aspects of Sor María's journal distinguish it from other convent writings consulted for this thesis. First, a remarkably short span of time separates the story "lived" from the story "told." Her words reflect a high degree of immediacy, as in September when she writes: "Today and as I write this, it comes alive and my heart trembles."145 The sense of immediacy is there for the reader, as well. Sor María's accounts of events, both within the real time of the convent and the spiritual time of her visions, take place within days of having occurred. She is both eye-witness and "journalist." Second, certain themes and events repeatedly are taken up by the author for review and analysis in light of her mission as a nun, not the least of which is her recordkeeping. Clearly an overriding intelligence is at work here selecting and giving form to the content. In chapters 3 and 4, this thesis will discuss a number of events and relationships to demonstrate how Sor María's spiritual diary reveals both her unique personality and issues facing her life in this eighteenth-century convent in New Spain.

${ }^{144}$ White, The Content of the Form, x.

145 AHPFM, María de Jesús Felipa, Diary, 115. "Hoy y como cuando escribo esto, me pone al vivo y me tiembla el corazón." 


\section{CHAPTER THREE}

\section{Behind These Walls}

Despite the antiquity of script and language, the journal of 1751 of María de Jesús Felipa establishes intimacy with its modern reader from the very first page of the January record. Addressing her confessor as Your Reverence, she establishes a voice that is almost insistently engaging. Noting the liturgical date, The Feast of the Circumcision, the author complains about the state of her health. Since this is a diary of her inner life, the reader is not immediately clear whether Sor María is writing about her spiritual or physical health. Perhaps both, since her sorry condition has a grievous impact on her ability to do her chores. ${ }^{146}$ Chores, however, are not to be confused with vocation. Details about the day-to-day responsibilities and cares of María de Jesús Felipa, her age, social status, upbringing and education are not easily brought to the surface. Nor does she provide any explicit description of the pattern of life within this particular convent. In the main, the subject matter is spiritual. The journal makes no overt attempt at autobiography. The reader must sift through clues in order to understand the culture of the cloister in which the diary was written and the lifestyle of its inhabitants. This chapter considers a selection of events which Sor María found important enough to review as part of her spiritual journey. These events involve human relationships that provide a window into life within the convent and the psychology of its observer.

\footnotetext{
${ }^{146}$ Sor María describes her malaise as "that torment I was feeling in all parts of my body, from my head to my feet. And that is why, when I am like this, I neither want to see people or be among them, since each step pierces and bores a hole in me in the deepest entrails. . .I would like to be in this my retreat, but I have to be in the choir; and that when it is looking like the chores are getting done, others appear that I cannot turn over to someone else.” AHPFM, María de Jesús Felipa, Diary, 2. See Appendix A (14).
} 
Sor María was a black-veiled nun, who -- if she professed in her early twenties as was the custom -- was probably in her mid-thirties or older when this journal was written. ${ }^{147}$ Her status within the convent may have been somewhat senior in that she was a maestro and spoke frequently and appeared to have a close relationship with her Mother Superior. ${ }^{148}$ Sor María was literate beyond the basics of being able to read devotional literature and penning her name. She was comfortable expressing herself in the written vernacular beyond keeping a journal. In at least one instance, she played an important role unrelated to any office within the convent. Most specifically, she petitioned her own brother, Don Pedro, to cover debts the convent had incurred. ${ }^{149}$ About this time, Don Pedro also provided her with new clothes. Sor María's confessor was involved in both these transactions: first, in granting the abbess permission to let Sor María write to her benefactor and, second, in letting Don Pedro know that his sister needed clothing. ${ }^{150}$ Sor María portrays her responsibility in negotiating the loan as key, without taking credit for the outcome.

${ }^{147}$ The fronticepiece of the 1751 journal lists it as the twelfth volume in the series. It is unlikely that she began keeping a journal until she received the veil -- at the age of 20 , at the earliest, which would put her 32 years of age when the record in question was kept.

${ }^{148}$ The appellation "mi Me" (mi Madre) is blotted out in all instances but one.

${ }^{149}$ The August journal entry reads like a short story. As the drama unfolds, a complexity of issues and forces, both human and supernatural, come into play. Sor María appears as protagonist and narrator, altering her voice with each occasion and interaction in an almost "Live from San Juan de la Penitencia" reenactment. The thesis will take a closer look at the event later in this chapter. AHPFM, Sor María de Jesús Felipa, Diary, 90-103v.

150، [Your Reverence] came to let me know that it was all arranged as asked for: that the gentleman had taken kindly to the request. You both came and were with me. Your Reverence, knowing that I needed some undergarments, told him. And by and by, he sent a shirt, underdrawers and a handkerchief, never mentioning that you had told him." Ibid., 99v. See Appendix A. (15). 
The prelude to her offer to write Don Pedro is as interesting as the role she plays in securing the funds. Sor María records how, during the course of daily penitential rituals with her Mother Superior, demons planted the notion that both she and her superior were a drain on community coffers: that they would be better off outside the convent than in it. Debate over debts became significant enough within the cloister walls that voicing the need to pay them became a bone of contention between her, the Mother Superior and the convent's financial steward. Sor María reflects on her sorry state-ofmind concerning the whole business:

This added to the fact that my Mother Superior had gotten so angry with me because I said she should pay our debtors even if it meant we would be left with nothing -- that it should shame me [according to the Mother Superior], because all I cared about was clothing myself. The devil put shame in her [for the public airing of the convent's financial woes]. She was so tortured and was of such a mind that between them they [the devil and the Mother Superior?] came up with or gave credence to a story that reached the ears of the financial steward, berating me in her [Madre Mayordoma] presence in a way that broke my heart. ${ }^{151}$

A secret her brother shared with her during his visit -- his request for counsel over a decision to marry -- further complicated the state of her anxiety.

Sor María's part in negotiating the loan and the way in which she recorded it reveal a number of things about her and the atmosphere within the convent. First, she voiced her opinion both orally and in writing, even though her transparency caused injury to others. Second, she positioned herself as both active and compliant in carrying out the wishes of her superiors. If she erred, it was on the side of candor. Contention was introduced as the work of others, both human and supernatural. Third, her social connections -- a well-to-do benefactor in her brother -- separated her from those around

${ }^{151}$ Ibid., 93v-94. See Appendix A (16). 
her. They were a potential source of suspicion. Finally, the level of gossip within the convent was high.

In addition to using her writing skills to help solve a community problem, Sor María regularly wrote personal letters. Her journal includes references to letters already written and intentions about writing others. She also writes of receiving written messages. Provoked by a fellow sister for her objection to the poisoning of the stray dogs by the portera, she was calmed when she received a note begging her pardon. When she wrote her confessor that she had rescued one of the dogs, he sent her word in writing that she must give it away. ${ }^{152}$ When the convent's chaplain was laid low by an attack of gout, she penned a note of consolation. ${ }^{153}$

In one instance, the diary contains a verbatim account of a letter destined for her brother. Though the sub-context of the letter concerned Don Pedro's request for her advice about a marriage prospect, the inclusion of its citation within the journal illustrates the eye-witness nature of her narrative. Here are the words Sor María tells her confessor she intended to send to her brother:

Señor Don Pedro: I am nothing, and I am good for nothing. And as Your servant and slave, at any rate, I present myself -- looking at my little brother as the Lord has shown me this, as he has pointed out his minister. . . I must confer over this matter because it is necessary to seek consultation -- but with such secrecy that my lowliness causes no harm. Always fearing that some trap of the devil may come my way, rest assured how heavily this request weighs on me. ${ }^{154}$

${ }^{152}$ Ibid., 55; $55 \mathrm{v}$.

${ }^{153}$ As was typical of many of her communications, she had second thoughts about having sent the Chaplain a note. In this case, she wondered if the difficulties she caused her supervisors might have been a factor in the Chaplain's having taken ill. Ibid., 58; 59; 62; 72.

${ }^{154}$ Ibid., 98v. See Appendix A (17). 
The nun copied the letter from a separate piece of paper into her diary. Having written it, she contemplated burning the letter, or perhaps sending it on to the confessor accompanied by another letter explaining what it was all about. Should she, she wondered, keep silent about what she knew? What value did her decision-making over the matter have unless it was informed by divine guidance? ${ }^{155}$ Finally, she fit these wheels within wheels. Sor María turned over the responsibility of dealing with the matter to her confessor without revealing the nature of the confidence: that Don Pedro was thinking about getting married:

I said that since Your Reverence was my priest, it was right to show you my answer and for you to extol him, to animate him, to offer that he consult with you -- in order to remove any impediment, pointing out that he should only confer with his confessor and that it was only on his behalf that you received this news. I told Your Reverence that it seemed that as far as I was concerned, by putting the matter in your hands, there was nothing more for me to do. 156

She extricated herself from what could be construed as a clerical responsibility, but only temporarily. This "secret" was rolled into a discussion of the interest of the Inquisition might have in conventual politics. ${ }^{157}$ In a separate letter to the Chaplain, Sor María justified her reasons for keeping the confidence and received from him a "favorable"

${ }^{155}$ God finally came to her rescue in the personage of Jesus Christ: "Do not worry daughter. I suffered contradictions to fulfill the will of my Father." Ibid., 99. Appendix A ( ). ( Hija, no temas nada -que yo padecí contradicciones por cumplir la voluntad de mi eterno Padre.) Ibid,, 99.

${ }^{156}$ Ibid., 99. See Appendix A. (18).

${ }^{157}$ In June, María de Jesús Felipa made two references to a "secret," which she had neither shared with her confessor nor about which she had previously written. She referred to it as her silence concerning "a secret that could cost me eternal life." Though it isn't completely clear that the reference is to the confidence Don Pedro shared with her, it is possible that her delays in turning over copybooks allowed this later event to infiltrate an earlier entry. Ibid., 80v.The only other reference to a "secret" was in the month of August and following, where she wrote about her brother's visit. 
reply. $^{158}$

Sor María's relationship with the Chaplain, whom she refers to as Most Reverend Father, is the most consistently warmly portrayed of her human associations. Except for a couple of months during his illness, his physical presence in the convent was more continuous than any other outside figure. Sor María suffered during the time he was laid up. She prayed for him and for his recovery. She went to him with doubts and uncertainties and wrote him when her confessor was physically and emotionally unavailable. Although the Chaplain was a close confidant, Sor María wrote that he did not understand the depth of her personal doubts:

It pained me to see that Most Reverend Father seemed to show no concern for my pain, knowing that he was not unaware of it . . and contrary to what the devil tried to convince me, I kept on, saying -- when things were at their worst -- "God, make Most Reverend Father a saint.",159

Yet the Chaplain knew her nature well enough that he cautioned her tendency to overreact, telling her that she made "elephants of gnats." ${ }^{160}$ She often sought his solace, worried that he had given up on her, and may have enlisted his support in a way that put her at cross purposes with her confessor. It even may have been the Chaplain who requested that Sor María keep the journal. ${ }^{161}$

Sor María's regular duties included physical activities. She worried from time to

${ }^{158}$ Ibid., $115 \mathrm{v}$.

${ }^{159}$ Ibid., 12v. See Appendix A (19).

${ }^{160}$ Ibid., $105 \mathrm{v}$.

${ }^{161}$ Sor María sometimes expresses confusion over who is in charge. At one point, her confessor indicates that the cuadernos go first to the Chaplain, but when she speaks with the Chaplain, he tells her he has neither seen the copybooks nor the confessor. The convent abbess is never mentioned as someone who has any authority in either scheduling the completion of the pages or as a reader of their content. Ibid., 104$117 \mathrm{v}$. 
time that keeping the journal occasioned more work for the señoras (servants). She herself polished the cross on the staircase, arranged flowers, lighted candles, and saw to other details of housekeeping. ${ }^{162}$ She also held the keys to the coro (choir), where all the collective activities of the convent took place, not the least of which were the regular assemblies for prayer. ${ }^{163}$ Calling her work in the choir her major responsibility, she despaired that her mortification rituals impeded her ability to meet its demands, called attention to her physical woes, and ended in making more work for others. ${ }^{164}$ Commenting on her poor state of mind in September, she wrote: "This made me cross. I neither wanted to be alone or with others. Being so angry, I could not even put up with myself, nor did I want to go to prayer. And I really needed to do that because I was the only one who knew what was what.",165

Entries concerning specific relationships leave the impression that Sor María was a teacher: either maestra de mozas (servants) or maestra de novicias (novices). In January, she writes that a priest accused her of having advised another sister, possibly a postulant, not to take communion. ${ }^{166}$ In May, after a meditation on the gospel of loving

${ }^{162}$ Ibid., $62 \mathrm{v}$.

${ }^{163}$ As outlined in Chapter 1, most convents ordered their daily schedules around prayer. Nuns met for oral prayer at daybreak (lauds) and, then, several more times a day, often ending with matins (between nine and midnight).

${ }^{164}$ Ibid., 20, 44.

${ }^{165}$ Ibid., 113v-114. "Y esto me enfadaba. Ni quería estar sola ni acompañada. A este modo ni yo misma me podía aguantar, enfadándome de todo. Ni quería ir al coro. Y esto era fuerza, porque no había otra que entendiera lo de allí."

166 The context indicates that it was probably a visiting priest, Padre Gaspar, who verbally attacked her, having been passed information that Sor María had shared in confidence with the convent chaplain. Sor María defended herself, saying: "No. I am not condemned for this -- for other sins, maybe. The sister did no leave off taking communion and she has not stopped since; that is not even my role." Ibid., fol.10v. See Appendix A (20) 
one's neighbor, she writes that she would interrupt her solitary observance of Christian doctrine only in order to teach the little girls this "hidden science." ${ }^{167}$ In another entry, she refers to her students as "her beloved daughters." "168 In June, she writes of spiritual distractions that confused her work with the novices so much so that she became a subject of derision. ${ }^{169}$

In the copybook recorded for June, Sor María discusses her relationship with Rosa, a young novice. ${ }^{170}$ Lacking money sufficient for providing a dowry, Rosa was destined to leave the convent without professing. The girl was a particular favorite of Sor María, who praised her musical talent, but cautioned that talent alone would not earn her a favored place within the ranks of black-veiled nuns. ${ }^{171}$ Sor María includes almost playby-play details of the scenario concerning relationships between herself, the young girl, her family and others within the convent. According to Sor María, the grandmother of the girl was plagued by hardships. The Mother Superior was jealous of the relationship between the novice and Sor María and had told the confessor that the girl should be

\footnotetext{
167 The "hidden science" may refer to the penitential practices of Sor María. Ibid., 67. See Appendix A (21).

${ }^{168}$ Ibid., $105 \mathrm{v}$.

169 "I had to work doubly hard because I kept forgetting everything to such an extent that I did not know what I had before me or in my hand; and I ended up repeating prayers with the novices three or four times, fretting because I had lost track. They were talking to me and I did not get it. . . Others said to me: 'Stupid! Think about what you are saying.' I said, 'Yes,' and they laughed.” Ibid., 76v-77. See Appendix A (22).

${ }^{170}$ Ibid., 69v-71.

${ }^{171}$ Ibid., 70. "I laid out what was at stake in electing the vocation and she could see that musicians -- without dowries -- were like slaves." See Appendix A (23).
} 
returned to her parents. ${ }^{172}$ The episode created a great deal of turmoil for Sor María, who wrote extensively about her advice to the young girl. She told her to be obedient to her parents and alerted her to the dangers of deceitful men. ${ }^{173}$

In the course of describing the petty personal politics in the convent, Sor María reflects on her own state-of-mind and temperament:

This made me explode because if I said something in Rosa's defense, it would make things worse. So I just had to keep myself under control, putting up with it. For me, this is completely contrary -- to see an injustice and not be able to act. I am not very subtle because my nature is very intrepid and violent and more so in situations like this where I am put down as I was here. ${ }^{174}$

The journal is sprinkled with personal observations of such character traits, many of which impede her mission as a bride of Christ. She couches her commentary in standard disclaimers of humility -- "I am the lowest of the low," "I am nothing," "a shabby vessel" -- and her worthlessness as a woman. ${ }^{175}$ Interestingly, most pejorative references to her imperfect, female state issue from the mouths of her demons. ${ }^{176}$ Her guardian angels urge

${ }^{172}$ Special friendships among nuns and the "mothering" by senior nuns of younger ones were common in colonial New Spain. They sometimes interfered with the governance of the convent and contributed to political strife during elections. Lavrin cites Fr. Antonio Arbiol, who wrote for Spanish nuns in the seventeenth century, as admitting the possibility of dubious bonds among women, thereby touching on the danger of homoerotic involvements. Lavrin, Brides of Christ, 240. The demons who plagued María de Jesús Felipa admonished her for taking "pleasure" in nudity during penitential practices with her Mother Superior. See Chapter 4. Felipa, Diary, 70.

${ }^{173}$ Le di contras para que no se dejara engañar de los hombres. AHPFM, Sor María de Jesús

174 The archaic usage of the expression "estoy gorda" is ambiguous here. Does she means she is a "dolt" or a "bull in a china shop" in situations like she found herself in with Rosa? The comment is followed later by a description of feeling as if she is eaten-up inside. Whatever the accurate definition, her auto assessment as being "intrepid" and "violent" is amply backed-up by meddlesome commentary and actions elsewhere in the journal. See Appendix A (24).

${ }^{175}$ Ibid., 9, 13, 19.

${ }^{176}$ See Chapter 4. 
her to "manliness," whereas St. Augustine reminds her that being a woman can be advantageous and Jesus Christ lovingly calls her his "little pilgrim," "his shepherdess."177

In August, she laments her inaptitude for the vocation. She accuses herself of pride, self-centeredness and impatience. Picking up on the metaphor of the "making elephants of gnats" the Chaplain used to describe Sor María, she turns it to different use. She writes that, alone, she did not have the capacity to ward off self-doubts because they (the gnats) "sting" her in different parts of the body. They cover her with blemishes. That is why, when she is in such distress, she falls back for counsel of her confessor and her chaplain. ${ }^{178}$ Later in the same record, Sor María admits to being a "depressed" person. She is drawn to the negative. Arguing from a paradoxical perspective, she notes that sometimes evil can be a blessing in disguise. "What good is the love of God," she reasons, "if everything is going well?"179

The journal also provides proof of the ways in which Sor María sought to embody the vows she took upon profession. ${ }^{180}$ The January record opens with a reflection on the

${ }^{177}$ Ibid., 12, 48v, 49, 62, 143. In March, Sor María writes: “Although I am incapable and ignorant because of my sex, when it comes to these lessons from my two guardian angels, I learn a great deal and find that I am so enlightened that it prepares me for the great work that I have before me." See Appendix A (25). Chapter 4 explicates the ways in which the visions of Sor María belittle or strengthen her. The word "manliness" (varonil) appears two or three other times in Sor María's diary. It appears frequently in the writings by men about female saints, specifically Teresa of Ávila. Women colleagues/followers of Teresa (e.g. María de San Alberto) used it as a standard invocation of outstanding female virtue. In the case of Sor María, if she were a student of St. Augustine, it may evoke here his reference to the soul as "the man within."

178 This lyrical passage is part of a longer reflection over difficulties with the vows of obediency and humility in light of events and relationships within the convent. Ibid., 94-94v. See Appendix A (26).

${ }^{179}$ Ibid., 99v. See Appendix A (27).

${ }^{180}$ The theological virtues listed in 1 Corinthians 13:13, referred to here as las tres graciosas virtudes -- la fe, la esperanza y la caridad, generally get short shrift in the journal, in favor of those to which Sor María professed and others with which she writes she struggled most. Ibid., 3v. 
virtues of faith, hope, and love. The "missionary" priests who visited the convent likely had sermonized on the topic. The theologizing of Sor María could easily have been a regurgitation of words she heard during Mass, since her reflection segues into a discussion of purification, purgatory, and entrapments by the devil. The entire section has a kind of warmed-over feel, as if it were the notes of a schoolgirl being held up for review. November, the final chapter of the diary, closes with a discussion of virtues -primarily humility and obedience. ${ }^{181}$ Her voice subdued and reverential, Sor María promises -- in an "ecclesiastical" as well as in the "secular" sense -- to fix her mind, heart and soul on Christ crucified and indicates that her copybooks will reflect that pledge. ${ }^{182}$ She has read the lives of the saints, she writes, and sees that she is "without virtue": that from here forward, she will seek humility, patience, prudence, diligence and moderation. ${ }^{183}$ In a passage employing a rhetorical pattern repeated on more than one occasion, Sor María wriggles away from her history of nonconformist behavior -unsanctioned penitential practices and missed deadlines in turning in her journal -- to confirm that she will conform to what is being asked of her. ${ }^{184}$ She writes:

I am telling you this so that Your Reverence may see that I live what I profess: I do not know what obedience is (la obediencia no la conozco), because by nature, I am inclined to please those with authority over me. It is no great effort for me to do what is asked, even if it is against my

${ }^{181}$ Ibid., 134-45.

${ }^{182}$ Ibid., 136.

${ }^{183}$ She uses the opportunity here to add in "virtues" from among those juxtaposed to the Seven Deadly Sins. Ibid., 136v.

${ }^{184}$ Alison Weber describes a similar rhetorical strategy in the writings of Teresa of Avila as a "double-bind." Weber, Teresa of Avila and the Rhetoric of Femininity. See Chapter 4. 
wishes, because I find security in obeying my superiors and whoever else. ${ }^{185}$

Thus she fortifies herself for greater compliance, but in a context that is patently false.

Nowhere in the record of her dealings within the convent has she demonstrated easiness in bowing to authority. In a curious turn of logic, she writes that God has given her so many tasks because he does not like to see her idle and that her personal work -- her selfflagellation and other penitential rituals -- are at his bidding in behalf of the souls in purgatory. Such work consoles her for being such a miserable creature. ${ }^{186}$ "I am nothing special," she writes. "I shed no light other than to reveal my sinfulness. God keeps the account ... He has chosen me among so many souls, better equipped than I, to serve his greater exaltation and glory." ${ }^{187}$ These twists in logic and apparent contradictions free the nun -- as among the lowly -- to carry out God's will. Sor María apologizes for her apparent lack of obedience by heralding her conformity to the will of God. As God is her witness, she can do no other.

Theoretically, institutional authority within the convent rested with the Mother Superior. It made sense that the confessor of Sor María de Jesús Felipa ordered her to submit to a ritual of penance with the abbess to curb disobedient behavior. ${ }^{188}$ Before reviewing what these practices came to entail, let us note that Sor María regularly

${ }^{185}$ AHPFM, Sor María de Jesús Felipa, Diary, 137-137v. See Appendix A (28).

${ }^{186}$ Ibid., $137 \mathrm{v}$.

${ }^{187}$ Ibid. See Appendix A (29).

${ }^{188}$ In January, her confessor ordered Sor María to burn papers and drip candle wax on her body. He later modified the order by turning over its administration to the Mother Superior. Ibid., 13. The second order, to prostrate herself twice daily before the abbess, was put in place after a set-to Sor María had with the portera. Epistolary exchanges between her and another nun and a misunderstanding with a visiting priest had antagonized others within the convent. Ibid., 80. 
flagellated herself and wore painful undergarments to quiet doubts, subdue self-will, ward off demons and prepare for Communion. ${ }^{189}$ Penance was as important a vocational practice in conventual New Spain as prayer and nowhere is it more evident than in the spiritual records left by nuns such as María de Jesús Felipa. Prayer marked the division of her days; self-mortification subdued her flesh. Sor María tortured herself passively through the use of a metal spiked belt and undergarments that lacerated her chest, back and legs.

Essential to this practice was its secrecy. She often worried that others might read the anguish of her suffering on her face or be alerted to the use of iron bindings by the sound of her movements. ${ }^{190}$ In April, she wrote that her weakened physical state caused her fellow sisters to question her: “' 'What happened?' [they asked.] 'You look terrible!' 'I am dead on my feet,' I told them, laughing. They laughed and did not ask more."191 On another occasion, she was in such pain that she could not stand during prayers. She feigned a toothache so that her fellow sisters did not guess what she was wearing under

${ }^{189}$ She described one such instance when her thoughts turn to the story of a certain gentleman who had met with his day of judgment without having confessed. She was tormented by the agony of his pain: "I went to my retreat, I disrobed, and with the desire to lighten his suffering, I beat myself all about my body with as much rigor as I could muster. I hoisted my cross to my shoulder and cried with my whole heart for the sins of this soul, pleading for his redemption through the intervention of Saint Michael, as this was the Day of the Apparition of St. Michael the Archangel. Ibid. 63v. See Appendix A (30).

${ }^{190}$ Stephen Haliczer notes the upsurge of female religious enthusiasm in sixteenth-century Spain as women sought to imitate the "athletes of Christ" in the Middle Ages through extremes of selfabnegation and physical mortification. He writes that mysticism came of age by the middle of the seventeenth century with the 614 letters exchanged between Philip IV and María de Jesús de Agreda, prioress of the Franciscan convent that her mother had founded in their family home. Likely this is the Madre Agreda that Sor María de Jesús Felipa quotes in her diary. See footnote 113. Stephen Haliczer, Between Exaltation and Infamy: Female Mystics in the Golden Age of Spain (Oxford: Oxford University Press, 2002), 4-5.

191 ¿Qué tenía que estaba desfigurada?” Les respondía: “Me quiero caer muerta”. . . como se los decía riéndome. Se reían y no me preguntaban más.” AHPFM, Sor María de Jesús Felipa, Diary, 44. 
her habit. ${ }^{192}$ Frequently, she self-administers her penitential program outside the boundaries established by her confessor. ${ }^{193}$ In May, after a visionary experience with Jesus Christ, she alternated writing and mortification exercises in a white heat. She wrote: "The drills lasted from nine to one. I was aware that I did this without permission from Your Reverence, but I could not stop myself and, also, I remembered the general rule to follow the inspiration of God." 194

Her self-mortification included prostrating herself before the abbess of the convent and submitting to her punishments in a variety of forms. She did this on a regular basis until the confessor suspended the rituals and forbade that she continue the practice. ${ }^{195}$ Sor María described these exercises in a number of entries, although it is not completely clear when, how frequently and extensively these practices took place or exactly when they stopped. ${ }^{196}$ "Although the flesh feels it," she wrote, "the spirit rejoices." The only thing she regretted was her inability to experience suffering as fully

${ }^{192}$ Sor María writes that the best she can do is lean against a chair and elevate her foot, but that the pain was so great it brought tears to her eyes. If others saw the tears and asked her about them, she said it was a toothache. Ibid., 20, 20v. See Appendix A (31).

${ }^{193}$ At the lowest point in the relationship with her confessor, Sor María recalled that he disapproved of her "works" because she did them so relentlessly. He told her that "as far as my suffering went, that it was impossible that anyone should suffer as much as I did; that God was not a tyrant, that he permitted truces and at present God did not want Your Reverence to suspect that His goodness was a lie." Ibid., 105.

${ }^{194}$ That she knew the hour of the day must be owing to the cycle of the collective prayer the convent kept. The passage is notable for the transparency of her thought pattern: she records the practice, admits to ignoring the mandate of her confessor and then qualifies the decision by applying her own understanding of the "right" thing to do. Ibid., 64. See Appendix A (32).

${ }^{195}$ It is unclear exactly when the confessor forbade the mutual exercises. His curtailment of these activities and her own self-administered practices outside bounds he established is referred to obliquely in October. Ibid., 132. 
as her Beloved Husband. ${ }^{197}$ The abbess began the exercises with what Sor María describes as "general disciplines," and then proceeded to drop burning paper and hot wax on her body. ${ }^{198}$ This particular procedure was short-lived:

I would have carried out these practices for nine days but the brute lost all its strength. So I wrote Your Reverence that the obedience had been accomplished and how my body and soul felt greatly consoled, in any case, since the demons had fled. ${ }^{199}$

In a later entry she expressed her joy when her mortification rituals were once again put under the administration of her Mother Superior. Almost giddily she writes that the subjugation of "not even being able to breathe without her permission" (sujeta que ni respirara sin su licencia) broadened and calmed her interior. "I rejoiced to see myself a slave to the love of my Husband, unable even to move without special dispensation."200

The Mother Superior became part of a confessional triangle, as it were, in that Sor María was required to admit her guilt at the feet of the abbess twice a day, asking God to castigate her arrogance (soberbia), ill temper (iras y corajes) and haughtinesses (altiveces). With the transparency that characterizes much of this text, Sor María admitted to how humiliated and angry such practices made her feel: "I could not keep quiet; I had to let my Mother know what it cost me to profess my guilt and how much it offended me to put myself at her feet."201

\footnotetext{
${ }^{197}$ Ibid., 13v.

${ }^{198}$ References to specific disciplines as "general," "short," and, in one case, "the rosette," indicate that the convent or Order had established patterns and tools for penitential implementation.

${ }^{199}$ Ibid., 14. See Appendix A (33).

${ }^{200}$ Ibid., 80v.

${ }^{201}$ Ibid., 81. See Appendix A (34).
} 
For the most part, however, Sor María was an enthusiastic participant in these practices. She reasoned that punishment applied by another was more effective both for the salvation of her own soul and for the work she could accomplish for others: "When the punishment comes from the hand of another it is sweeter to the spirit and more meritorious [for others] because in a small way it duplicates [the Passion of] the One who endured so much for our sins." 202 Punishment meted out by another was "better" in that it has the potential of being more physically brutal and psychically demeaning. Sor María went so far as to recommend the practice to the Chaplain and her confessor: "Give it a try. Each of you will feel such effect that there will come a time that Your Reverance will know in the depth of your heart what you have most wished -- to serve Him in what is most to His liking.",203

Just how exaggerated these sessions became is clear from a look at the July journal entry. Here, Sor María described three such meetings with her Mother Superior. The first session involved tying her hands to a broomstick to prevent her from staving off the blows. "I know that this whipping did me a great deal of good," Sor María wrote. ${ }^{204}$ Physical pain during a second session brought tears to her eyes. "My Mother asked me why I was crying because even if I were, she said she had to fulfill her obligation." “Crucify me; if you wish, drip hot wax on the wounds," Sor María replied. Instead she was made to stretch out on the floor. The Mother Superior put her foot on the neck of Sor María and kept her in that position to cry. Then she told her to stand, tugged on her with a

\footnotetext{
${ }^{202}$ Ibid., 14v. See Appendix A (35).

${ }^{203}$ Ibid., 15. See Appendix A (36)

${ }^{204}$ Ibid., 81v.
} 
rope, brought her to her knees, and ordered her to write in that position. Meanwhile, the abbess repeated her prayers. Additional disciplines included verbal "abuse", spitting and setting a match to a candle in order to burn two papers -- one on her back, the other on the rest of her body. ${ }^{205}$ In this third instance, when Sor María admitted that her bedevilment was so tenacious that only God could comfort her body and soul. She wrote that, in recalling the episode, she was amazed that nothing came of it. ${ }^{206}$ Her Mother Superior had her disrobe, beat her doubly with the rosette -- a whip with "flower buds" of metal spikes -- doused her in cold water and forced her to write facing the cross. "You don't dress until I tell you," the abbess said. ${ }^{207}$

It is only after the confessor requested that Sor María return the favor and beat the abbess that the practice was suspended. Changing places did not last long; neither party could sustain it. Sor María described the problem like this:

What happens is my Mother gets mad, unhappy, bewildered -- worrying that if she dwells on the thought, how will she handle purgatory? And so instead of encouraging her, it throws her into confusion. After a few days it all came to a halt because seeing her so tormented and that this was the source of her tribulation, I suspended it [the activity], not doing it and depriving me of relief . . . Her reaction was always to cry and tell me nothing. When I saw her in such a state, my reaction was to encourage and console her and to leave off with what created greater torment for me . . . I called on the Lord to put it in Your Reverence's heart to suspend our exercises knowing that as far as for me it did me little good. ${ }^{208}$

\footnotetext{
${ }^{205}$ Ibid., 82-82v.
}

206 "Hubo día que estuvieron tan tenaces que sólo Dios me pudo confortar alma y cuerpo que ahora que lo escribo me sirve de admiración el que no me sucediera nada.” Ibid., 84v.

${ }^{207}$ Ibid.

${ }^{208}$ Ibid., 87v-88. See Appendix A (37). 
But Sor María missed these practices once they were curtailed. In her diary of 1758, she reported a more successful episode of mutual mortification. In this case, the punishments were satisfactorily administered and received alternately by the parties. ${ }^{209}$

The value Sor María placed on "punishing” her flesh cannot be overemphasized. It harkened to a tradition entrenched in late medieval Christianity and associated with saintly female behavior. ${ }^{210}$ During that time, priests -- many of them Dominicans -widely preached from the graphically described suffering of the early martyrs. ${ }^{211}$ What stands out in their fourteenth-century emulators was the intensity of their absorption in the Passion. Meditation on Calvary, as noted by Richard Kieckhefer, was not a source of consolation. Instead, it provided a blueprint for imitation. Atonement for the sins of oneself and those of others came from pain. ${ }^{212}$ Early modern examples of similar

\footnotetext{
${ }^{209}$ In Brides of Christ, Lavrin provides the following translated citation from the June 1758 journal: "I took charge of what I desired for myself, and that moved me to discharge the strikes and mortification, as I did, while she was praying the Miserere and De profundis. Then she got up and kissed my hands and feet, which I resisted, but she won ordering me to let her do it, and [then] she disciplined me, and it caused me such joy ... that my soul wrapped itself in the contemplation of the pains of my crucified husband. . and I did not feel the blows, and time passed fast." LC, Sor María de Jesús Felipa, Diary, fols. 78r-79, as cited in Lavrin, 194.

${ }^{210}$ See Dyan Elliott, Proving Woman. Female Spirituality and Inquisitional Culture in the Later Middle Ages (Princeton: Princeton University Press, 2004) for how the sacramental relationship between aural confession and the Eucharist following the Fourth Lateran Council (1215) paved the way for scrupulosity in female spirituality.

211 The Golden Legend, a compendium of hagiographic and liturgical documents compiled by Domincan Jacobus de Voragine in the late thirteenth-century provided illustrative examples of these heroic lives. See Martha Easton, "Pain, torture and death in the Huntingon Library Legenda aurea," in Gender and Holiness: Men, women and saints in late medieval Europe, eds. Samantha J.E. Riches and Sarah Salih (London: Routledge, 2002), 49-64.

212 Richard Kieckhefer, Unquiet Souls: Fourteenth Century Saints and Their Religious Milieu (Chicago: University of Chicago Press, 1984. Note particularly Chapter 3 "Devotion to the Passion," and Chapter 4 "Penitence." 89-149. These would-be saints reduced their intake of food and mixed it with ashes, in imitation of St. Francis. They voluntarily subjugated their bodies to physical punishment. Not all of them were female. Kierckehefer extensively describes the self-inflicted wounds of Henro Suso, a fourteenthcentury German mystic.
} 
behavior in both Spain and the New World indicate that extreme asceticism was common in conventual life, sometimes bringing discord to the cloister and supervisory problems for the hierarchy. Clerics were often drawn to holy women convinced that the women possessed essential spiritual qualities or gifts they lacked. Similarly, there were those who denied the validity of such a calling and took an authoritarian position. Susan Laningham has made a thorough study of one such ascetic in Spain and the confessors who supervised her over a period of many years. María Vela was an early seventeenth-century Cistercian living in Avila, whose mysterious ailments prevented her from eating. ${ }^{213}$ Heavenly visions and voices convinced the nun that her series of illnesses -- spasms in her joints, fluid in her lungs, seizures and a locked jaw -- were gifts from God. Such convictions had been subject to the scrutiny of the Holy Office for centuries. ${ }^{214}$ The behavior of María Vela and attempts at its management caused periodic chaos within the convent and exhausted a series of confessors.

Frequently, the capacity of these women to self-inflict physical pain and endure punishment administered by others fascinated their biographers and confessors. ${ }^{215} \mathrm{Joseph}$

${ }^{213}$ Laningham looks at the relationship between María Vela and five confessors who monitored her maladies over a period of many years. She concludes that the nun asserted her power through her body to: 1) bypass clerical authority; 2) rescue souls in purgatory; 3) preach without a pulpit; 4) declare her own sanctity. Laningham, "Maladies up Her Sleeve?", 69-97.

${ }^{214}$ As noted by Elliott, discernment of sainthood in the fourteenth century increasingly came to be informed by "a quasi-medicalized discourse that tended to disparage women and pathologize some of the most characteristic aspects of their spirituality, particularly the ill health associated with divinely inspired somatism or scrupulosity in confession. Elliott, Proving Women, 300.

${ }^{215}$ See Alison Weber, "Gender and Mysticism," Cambridge Companion to Christian Mysticism, ed. Amy Hollywood and Patricia Beckman (Cambridge: Cambridge University Press, 2011), 15 (forthcoming). Other scholars who explore the relationships between nuns and their confessors are John Coakley, Women, Men, and Spiritual Power: Female Saints and Their Male Collaborators (Columbia: Columbia University Press, 2006) and Asuncion Lavrin and Rosalva Loreto López, eds. Diálogos Espirituales: Manuscritos Femeninos Hispanoamericanos, Siglos XVI - XIX, (Puebla: UDLA, 2006). 
Eugenio Valdés, the biographer of Sebastiana Josefa de la Santísima Trinidad, is one who held up such behavior as heroically virtuous and suitable for emulation. ${ }^{216}$ However, the case of Sebastiana Josefa is remarkable for another reason. She was a close contemporary of the subject of this essay, living in the same convent that Sor María indicated in 1758 also was hers: San Juan de la Penitencia. Sebastiana Josefa died in 1757, just six years after the diary considered here was written and while Sor María presumably was living there.

In Brides of Christ, Lavrin notes that both of them kept journals, presenting the “intriguing possibility of identifying this convent as a center of spiritual writing., ${ }^{217}$ More intriguing, I would venture, is the emphasis that both women placed on self-mortification and the level to which it was condoned, perhaps even encouraged, behind the walls of San Juan de la Penitencia. Literary scholar Kristine Ibsen has made a study of Sebastiana Josefa. She argues that this nun managed to transform her body into a baroque work of art and ended by starving herself to death. ${ }^{218}$ Margo Glantz, who has written extensively about the Baroque in the writings of Sor Juana Inés de la Cruz, would support such a perspective. According to Glantz, we may speak of baroque culture as comprising a "corporeal rhetoric: a system of theatricalized signs through which sanctity itself is

${ }^{216}$ Joseph Eugenio Valdés, Vida admirable y penitente de la V.M .Sor Sebastiana Josepha de la SS.Trinidad. (Mexico: Bibliotheca Mexicana, 1765, as cited in Kristine Ibsen, "The Hiding Places of My Power," 252.

${ }^{217}$ Lavrin, Brides of Christ, 335.

${ }^{218}$ Ibsen, “The Hiding Places of My Power," 251-270. 
systematized." ${ }^{219}$ Sebastiana Josefa so exploited the subjection of her tongue as the embodiment of sensuous appetites that she crawled on her knees, marking each tile of the patio with bloody crosses. Penance thus became performance art. ${ }^{220}$ For María de Jesús Felipa, the theatrical is also present. "Crucify me!" she shouted to her Mother Superior -so strong was her desire to re-enact the Passion.

The closeness between Sor María and the nun she refers to as my mi Madre runs through the 1751 journal like a thread binding the spiritual and material worlds. On more than one occasion, she writes that their bond is congenial to the heavenly host and offensive to the Devil. ${ }^{221}$ But if this individual, whose appellation is obscured, is the abbess of the convent, her role in relation to Sor María is not portrayed as supervisory. Although ordered by her confessor to prostrate herself before the abbess, Sor María assumed an advisory position to her on more than one occasion. She even promised to cover for her if the Holy Office called their penitential practices into question. ${ }^{222}$

The Santo Oficio is mentioned frequently in the diary. References to the Inquisition are scattered throughout the journal, most particularly in terms of how the records of Sor María would be scrutinized for aberrant management within the convent and her own heresy. She also cogitates frequently on whether or not she should "leave"

\footnotetext{
${ }^{219}$ Margo Glantz, "El cuerpo monacal y sus vestiduras," in Mujer y cultura en la colonia hispanoamericana, ed. Mabel Moraña (Pittsburgh: Biblioteca de América, 1996), 171-82, as cited in Ibsen, 254.

${ }^{220}$ Ibsen, 259.

${ }^{221}$ See Chapter 4.

222 The record for September includes a (one-sided) conversation between herself and the Mother Superior, in which the nun tells the abbess not to follow her bad example and takes upon herself all the blame for their misguided and aborted penitential practices. AHPFM, Sor María de Jesús Felipa, Diary, $111 \mathrm{v}$.
} 
the convent. As noted by Lavrin in Brides of Christ, such musings were pipe dreams. Once a nun professed, she submitted to enclosure for life, even if her behavior warranted excommunication and social ostracism within the cloister. ${ }^{223}$ Yet, Sor María expressed misgivings about her suitability for the vocation and regularly wrote about leaving. Her demons even advise her to leave, on one occasion quite aggressively. "It is best that you go," they urge her to flee. "Get out! [Then] you can confess with anyone you choose. Leave these two [her confessor and the Chaplain]."224 Such thoughts came to her when relationships within the convent were most contentious or when she perseverated over the effect the content of her copybooks might have in the hands of the Holy Office. Her fears were not ungrounded, according to the diary of 1751 . Her confessor already had gone on record with complaints about their content. On one occasion he told her she included too much information about day-to-day problems within the convent. ${ }^{225}$ On another, he objected that she included references to the "secret" of Don Pedro. ${ }^{226}$ Most of all, he was unhappy that she detailed the penitential sessions in which she participated with the Mother Superior. $^{227}$

It is not that her confessor necessarily lacked clarity in letting Sor María know what she should write about, nor that he demurred about getting a wider audience for her

\footnotetext{
${ }^{223}$ Lavrin cites a few cases where sexual misconduct resulted in the censure of nuns by the Inquisition in her chapter, "Sexuality: A Challenge to Chastity." Lavrin, 209-243.

${ }^{224}$ AHPFM, Sor María de Jesús Felipa, Diary, 124.

${ }^{225}$ Ibid., 108v.

${ }^{226}$ Ibid., 107v.

${ }^{227}$ Ibid., 105v.
} 
visions and voices. After a particularly stormy session in the confessional in which Sor

María described her head as being full of flies, they had a breakthrough:

Your Reverence told me -- I do not know how -- but it brought peace to the troubles that had oppressed me and caused me anguish ... "Daughter: Write as you are now, so that I may take charge of your afflictions. Do not be afraid. It is best that you put on me all that you feel. I will take it to the Holy Office." When I heard that I told Your Reverence: "Okay, then. If it is meant to be, I will write what you ask of me." "Yes, daughter. That is what I want.",228

It would be felicitous if that moment portended smoother sailing for their relationship and that Sor María achieved a greater peace of mind and clearer understanding of her vocation, but it did not. What is evident is that both she and her confessor sought a wider readership for her diaries. ${ }^{229}$ Both took her voices and her visions seriously. ${ }^{230}$ These visions and the part they played in Sor María's life is what we will look at in Chapter 4.

${ }^{228}$ Ibid., 131. See Appendix A (38).

${ }^{229}$ Sor María vacillated in her conviction that the Holy Office would exonerate her orthodoxy. Ibid., 65, 88v, 100, 107, 107v, 110, 123, 129v, 130.

${ }^{230}$ Scholarly research into the preoccupations of the Inquisition in colonial Mexico indicate that sexual morality, witchcraft and, in the eighteenth century, the political loyalty of the clergy (and laity) were of much greater interest than the orthodoxy of an individual nun, unless a controversy spread beyond the walls of a convent. For further study, see Ruth Behar, "Sex and Sin, Witchcraft and the Devil in Latecolonial Mexico, American Ethnologist 14 (1987) 34-54; Mary Elizabeth Perry and Anne J. Cruz, eds., Cultural Encounters: The Impact of the Inquisition in Spain and the New World (Berkeley: University of California Press, 1991; and Richard E. Greenleaf, The Mexican Inquisition of the Sixteenth Century (Albuquerque: University of New Mexico Press, 1969). 


\section{CHAPTER FOUR}

\section{Supernatural Visitations}

In her record of July 1751, Sor María de Jesús Felipa writes about a visitation

from a demon. He taunts her. He questions the authenticity of her perceived ill health and the value of the spiritual record she is keeping for her confessor. Through a disembodied voice he tells her:

You have brought this punishment on yourself. This pneumonia will not count or keep you from escaping purgatory because of ill health. Look at you! Enslaved by your own will, writing as a lashed captive -- you could be enjoying life, but you are not .... To what end do you lose time, your soul, your credit, because, if such silliness comes to light, you will find yourself in an outrage[ous situation]? ... . Do you not know that God is worthy of all reverence and you are but a worthless woman, a wallowing pig? Who told you that this Lord, who does not [allow] us to see him because of his grandeur, should be your bridegroom? Get out! Do not fix on such fantastic illusions that, truly -- with your permission -- I tell you the truth. ... These men love to read foolishness and it's their pleasure to make you write. They know well that everything is false. . . You will see that it provides them entertainment. They are deceiving you and you them and thus you [they] go through life in continual laziness. Remember what I tell you. You will see when least you are expecting: they [will] doubt all and then you will remember me; then you will curse your bad judgment and having obeyed whom you should not have. ${ }^{231}$

This episode is the second of two encounters with supernatural enemies that Sor María records in July. It is emblematic of twelve such events in her diary of 1751 in which she quotes at length the malevolent taunts by demons. The encounter, like many others, is highly conversational, reading like a response to inner doubts about self-worth in general and the writing enterprise in particular. This devil also takes a swipe at Sor María's supervisors, upholding and distorting the theological hierarchy of her spiritual world:

\footnotetext{
${ }^{231}$ AHPFM Sor María de Jesús Felipa, Diary, 86-86v. See Appendix A (39).
} 
God is grand -- too grand for the likes of Sor María. Her enemy's presence here is oral rather than visual, although sometimes her malevolent visitors make themselves known by their groans and odors. ${ }^{232}$

The two visitations by demons in the July record are separated by a passage in which Sor María writes that her thoughts leapt from one subject to another, followed by a period of clear-headedness when the act of writing itself seemed to stave off their bedeviling voices. Immediately prior to her citation of the demon's words, she had provided a detailed narrative of physical abuse rained down on her by the abbess. ${ }^{233}$ Spiritual and human times are intertwined: content is privileged over chronology. What the demons say is more important than when they say it.

The language of the demon(s) is always rueful, abusive and familiar. He addresses Sor María in the "tú" form, reserved for children, equals, intimates, or underlings and for God. His tirades generally cover the same ground: Sor María is characterized as unworthy of God's attention and as a candidate as a bride of Christ. She is, on the one hand, self-important and intrusive in the affairs of others, on the other, lacking in faith and a lazy, fraudulent liar. According to her demons, the penance her confessors have conferred on her in keeping a diary makes no sense because she is unlettered and unreliable. It will only be a matter of time before she is revealed as a charlatan. When it comes to her confessors and the others who people Sor María's world -- her fellow

\footnotetext{
${ }^{232}$ In March, she complains of a bad smell and "creepy, crawly" sensations because of recent contact with devils. In the first July encounter, the demons poke and dance around her as her Mother Superior whips her. In October, she hears voices telling her "do not do this; do not do that." Later, the devil calls her an "infamous, traitorous bitch" and turns into a fire-breathing dragon she must defeat with the help of St. Michael and her guardian angels. Ibid., 40, 41v, 84, 124, 128.

${ }^{233}$ The name is scratched out in another color of ink, but the digitalized copy made for me by the archivist in Celaya reveals the abbreviation "mi Me" ( mi Madre): in other words, her Mother Superior.
} 
sisters, her Mother Superior, her students and protégées, her brother, even a gentleman who has solicited her prayers -- they are alternately spoken of with pity, compassion or disdain. The demon recognizes his place as separated from God, but as a former angel, he presents himself as an authority on the workings of heaven. ${ }^{234}$

Of all Sor María's interlocutors from the spirit world, including God, Jesus Christ, St. Augustine, St. Lorenzo and St. Philip (her patron saint), the devil gets the best lines. He cuts her no slack when he outlines how far she falls short of sainthood. Almost like an angry schoolmaster, he instructs her that:

No saint was a talker; they prayed silently. They cut their bodies to shreds in penance. They did not sleep in beds, but [rather] on the ground in great torment. They did not eat or have as much freedom as you do.... Who do you think you are -- pretending you are sick, writing lies, sleeping and eating like all the others? Come to your senses, woman! Repent your evil ways. How is it you demonstrate none of the famous acts of love? You do not fast or perform acts of discipline or mortify the flesh. You sin knowingly, not out of ignorance. From here, henceforth, all that you write is false, deceptive; and if those idiots do not know error when they see it, I will put them straight so that no one is misled, because it is not just a question of your soul but of others' as well.,"235

The demon may be otherworldly, but he shares the same cosmology as Sor María. It is a world populated by saints, sinners and hierarchical institutions that are the mirror image of a universe overseen by a heavenly Father. No heresy issues from the devil's lips. He exhorts her to holiness. Yet his conversations with Sor María call her orthodoxy into question. He not only characterizes her as falling short of the Desert Fathers, but of

${ }^{234}$ Like all of Sor Maria's supernatural visitors, her demon is loquacious and articulate. The length of these citations, presumably recalled verbatim, is stunning. I have not uncovered soliloquies of similar length among other written accounts left by visionaries.

${ }^{235}$ Ibid., 39v, 40. See Appendix A (40). 
sinning knowingly - presenting herself as saintly material, with special access to the Godhead and a danger to others around her.

Sor María's encounters with malevolent apparitions put her in the company of a host of saints and heretics and a tradition that reaches back to biblical records. Jesus himself was tested by the devil during the forty days he fasted in the desert. All three of the Synoptic Gospels -- Mark, Matthew and Luke -- carry the story of his trials by Satan. Both Old Testament and New contain narratives of diabolic visitations. In his letter to the Corinthians, St. Paul writes that Satan disguised himself as an Angel of Light and advocates a policy of discernment: "Do not quench the Spirit; do not despise prophesying, but test everything." 236

Battling demons was an integral part of late medieval and early modern conventual spirituality. Teresa of Avila suffered throughout her career from doubts and anxiety, concerned that her visions could have been of demonic origins. She writes:

Since at that time other women had fallen into serious illusions and deception caused by the devil, I began to be afraid. . . I began to fear and wonder whether the devil, making me think the experience was good, wanted to suspend the intellect so that he could draw me away from mental prayer and so that I might not think upon the passion or benefit from the use of the intellect. ${ }^{237}$

Teresa warned against visions and recommended their resistance. She recommended both penance and correction by the superior: use of the "whip" could cure the unregulated spirits that could disrupt the harmony of the community. On the other hand, Teresa

${ }^{236} 2$ Cor 11.14; Thess 5. 19-21 RSV.

${ }^{237}$ Teresa of Avila, "Life," 23.2, The Collected Works of St. Teresa of Avila, vol. 1, trans. Kavanaugh, Kieran and Otilio Rodriguez (Washington, D.C.: Institute of Carmelite Studies, 1976), 152, as cited in Moshe Sluhovsky, "The Devil in the Convent," The American Historical Review, 107.5 (December 2002), 1401. 
always "doubted the fine line between divine and diabolic strenuous self-

mortification." ${ }^{238}$ In these matters, she urged moderation -- moderatio. In a letter to the Carmelite convent in Mancera, she asked the sisters "not to practice such severity in matters of penance ... afraid that the devil might be trying to bring their work to an end." Visions that result from self-mortification, she warned, are abobamiento (silliness) rather than arrobamiento (rapture.) $)^{239}$

Teresa was not alone in her suspicions about visitations from the spirit world. Two hundred years earlier, Bridget of Sweden (1303-1373) was praying in her chapel for help in coping with the recent death of her husband when she entered a state of rapture. A voice from a cloud demanded: "Woman, hear me." The experience occurred again and again, until the voice reassured her she was not delusional and urged that she get confirmation from Master Matthias, her confessor, an expert in the discernment of spirits. Catherine of Siena (1347-1380) is said to have experienced levitation within the cave outside of town where she began her life as a hermit. She blamed it on the devil's intervention. As an adult, she was afflicted by the devil as she lay in bed, causing her to beat her head against a jar full of burning coals, breaking it and spilling the coals on herself. ${ }^{240}$ Demonic possession, as in the case of St. Catherine, was sometimes seen as

${ }^{238}$ Teresa of Avila, "The Foundations," 14, vol. 3, 168; “The Interior Castle," 4:3, vol. 2, 328-29, as cited in Sluhovsky, 1404.

${ }^{239}$ As covered in Chapter 3 of this thesis, regulation of Sor María's penitential program was a bone of contention with her confessor. Although it is impossible to draw a direct line between the rigor of her mortification practices and the vitality and frequency of her visions, there is evidence of a triadic relationship between her physical penance, her writing and her visionary life.

${ }^{240}$ Kieckhoever, Unquiet Souls, 175. 
praiseworthy, evidence of a saint's ability to suffer a slow martyrdom. ${ }^{241}$ "Positive possession by demons," writes Alison Weber, "can thus be seen as part of a continuum with saintliness at one interpretative extreme and witchcraft at the other." 242

In Sor María's record, the apparitions, voices and sensory presentations of demons -- "my enemies" (mis enemigos) -- are carefully differentiated from those of her heavenly supporters. The devil neither tests her as he did Jesus, not does he possess her as he did St. Catherine. Yet the presentation of these apparitions would have been motive for her superiors to require recordkeeping of her experiences. ${ }^{243}$ From what source did these spiritual encounters emanate?

Discussions over discernment of spirits originated within the early Church. In a letter to the Corinthians, St. Paul names two sources of perception: one a God-given gift to be shared communally; the other established by affirmation of the beholders. ${ }^{244}$ Over the centuries, the historical church developed mechanisms and a system of courts in order to pass judgment on these matters. Diagnostic tools employed by abbesses, bishops, theologians and confessors as well as remedies, such as exorcism had been used for centuries. $^{245}$

${ }^{241}$ Alison Weber, "Gender and Mysticism," Cambridge Companion to Christian Mysticism, ed. Amy Hollywood and Patricia Beckman (Cambridge: Cambridge University Press, 2011), 15. (forthcoming).

${ }^{242}$ Ibid., 6.

${ }^{243}$ It is more likely, as we will see later in this chapter, that the support of Sor Maria's guardian angels, Jesus Christ and various saints would be seen as her "tempters," instilling in her a sense of unwarranted self-importance.

244 “Thus you will know them by their fruits;" 1 Cor 12.10; Matt 7.10 RSV.

245 In Chapter 29 of Libro de la Vida, Teresa de Avila gives a somewhat tongue-in-cheek summary of the methods certain unnamed priests required her to employ to resist the heavenly visions they judged were presented her by the devil. She dutifully followed orders, alternately crossing herself and 
Theological interest in codifying criteria for discerning spirits reached an apex at the end of the fourteenth century and was part and parcel of the chaos surrounding the Great Schism (1378-1417), a period in which two papacies -- and for a time even three -reigned: one or two in Rome, another in Avignon. ${ }^{246}$ This foundation was elaborated on by Jean Gerson (1363-1429), chancellor of the University of Paris, in "De Probatione Spirituum" which, along with Ignatius of Loyola's Spiritual Exercises, written 130 years later, became the doctrinal and practical source on discernment. ${ }^{247}$ Issues raised by both Gerson and Ignatius created the climate in which the written testimonies of visionary women in early modern Catholicism became sources of scrutiny by the Church. Ignatius wrote that the sensation of the spirit in the soul could serve as a sign of God's presence: "the good angel touches the soul sweetly, evenly and softly, like a drop of water that penetrates a sponge; and an evil one touches it sharply and with noise and disturbance as when a drop of water falls over a rock." ${ }^{248}$ Thus, the personal experiences of Bridget,

shamefacedly "giving the fig" whenever she came upon a vision of Christ as she made her rounds of the convent. Teresa of Avila, "Life," 29.5. The Collected Works of St. Teresa of Avila, trans. Kieran Kavanaugh and Otilio Rodriguez, Vol. 1 (Washington: Institute of Carmelite Studies, 1976), 190. Making the hand gesture of "the fig" was a sexually explicit sign of disrespect.

${ }^{246}$ See Kieckhoever, Unquiet Souls, for the extensive debates concerning discernment took place around the canonization of Bridget of Sweden, whose visions were so controversial as to require three separate canonization procedures. Polemic surrounding Catherine of Siena was no less heated.

${ }^{247}$ Elliott elaborates on the political/religious setting in which the late fourteenth-century discernment debate took place in "Seeing Double: Jean Gerson, the Discernment of Spirits, and Joan of Arc," American Historical Review, 107. 1 (February 2002). Elliott writes: "the triune disasters of the Black Death, the Hundred Years' War, and the papal schism created a vacuum in institutional authority into which female mystics and prophets would move. These women not only captured the imagination of the public but even won the confidence of popes and princes. . The authority of these women depended on Christendom's conviction that they were not merely speaking in their own voices but that it was the voice of God which spoke through them," 26. In Proving Women Elliott focuses on the role female mystical experience played in creating a system for assessing the validity of visionary piety.

${ }^{248}$ Ignacio de Loyola, Obras, ed. Ignacio Iparraguirre, Cándido de Dalmases y Manuel Ruíz
Jurado, 6th ed. (Madrid: B.A.C., 1997), 335, as cited in Ivan Fernández Peláez, “Teresa de Jesús y el 
Catherine, Teresa and those who followed, including María de Jesús Felipa, served as a test as to the authenticity of the source.

Gerson himself had admitted that it was practically impossible to arrive at a theoretical test for discerning the difference between bedevilment and celestial communication, a caution repeated by Bernardino de Laredo, whose Subida del Monte Sión Francisco de Salcedo y Gaspar Daza ordered Teresa to read. ${ }^{249}$ Though Laredo offered external criteria for discernment -- obedience, charity, humility, toughness, penitence -- these qualities would only be apparent to others over time. Thus, discernment by human means was next to impossible. The authority of the confessor was diminished as that of the subject's experience was increased.

The Lives of the Saints literature -- read to nuns during meals and recreación (free time) and referred to in sermons -- and the existence of the Inquisition kept the issue of spiritual discernment alive, both in Spain and in the New World. Early modern nuns looked to their predecessors. They modeled their lives -- spent in prayer, penitence and in pursuit of the virtues -- striving to achieve the union with God that the saints before them had achieved. All the while, they were aware that such supernatural experiences could bring scrutiny and censure.

How must the confessor of María de Jesús Felipa, her Mother Superior, the Chaplain, and even the Holy Office, have looked upon her visionary record? What criteria besides a lack of orthodoxy make the supernatural encounters subject to censure? discernimiento de espíritus: Una hermenéutica de ida y vuelta" (Long Beach: GEMELA Conference, Oct. 4, 2008), 3-4. (Translation is mine.)

${ }^{249}$ Fernández Peláez, 6. This excellent essay exposes the internal contradictions in the tests for discerning spirits that Teresa of Avila exploited to defend her visionary life. Fernández builds on Weber's characterization of Teresa's rhetoric as "feminine." 
According to the established guidelines for discernment, the experiences themselves should be looked upon as authentic, unless statements made by the spirits, visions she recorded having seen, or actions taken by Sor María or by her interlocutors were deemed heretical. As compared to the rhetorical path chosen by Teresa in "proving" her visions, the record left by Sor María reads as guileless and straightforward. ${ }^{250}$

Upon further examination, the relationship between Sor María and her demons varies from many of the encounters described by others. For one thing, the demons that bedeviled Sor María de Jesús Felipa never possessed her. Nor did they torment her physically, though she was no stranger to rigorous penitential practices whether selfinflicted or administered by another nun. Sebastiana Josefa de la Santísima Trinidad (1709-1757), who lived in San Juan de la Penitencia at the same time as Sor María, as noted in the previous chapter, complained of shortness of breath or suffocation and fainting whenever the devil was near. She reported being hit in the stomach or having the devil reach a hand inside her to pull out her entrails. Additionally, she described the devil to her confessor -- something Sor María does not do -- as naked, large and very crude. "He crushed my whole body with such force that it burst me apart," her biographer reports her as saying."251

${ }^{250}$ Barbara Mujica points out that Teresa's description of spiritual sensibilities differs from the theologians of her period. Theologians wrote about perceptions of physical and intellectual utterances using an auditory metaphor: the physical are perceived with the ear, on the exterior, the intellectual with the spirit or on the interior. Teresa used the visual, describing three types of visions: the corporeal, which is seen with one's own eyes; the imaginary, in which one "sees" an image with his or her inner senses; and the intellectual, where there is no image, but which occurs when one senses or is conscious of a supernatural presence. Women Writers of Early Modern Spain: Sophia's Daughters (New Haven: Yale University Press, 2004), 52.

${ }^{251}$ Joseph Eugenio Valdés, Vida admirable y penitente de la V.M. Sor Sebastiana Josepha de la SS.Trinidad (Mexico: Bibliotheca Mexicana, 1765, as cited in Kristine Ibsen, "The Hiding Places of My Power," 257. 
María de San José, who entered the Augustinian convent of Santa Monica, Puebla, in 1687, provides several long descriptions of demons who frequently tortured her physically and mentally, but without touching her "interior." ${ }^{, 252}$ She writes that a demon embraced her for two hours giving her "a thousand caresses and endearments" and "(broke) her in little pieces." While this demon was clothed, usually, she writes, he came "naked in the raw flesh" or "in the form of a wolf or a black dog" (with) "his waist cinched in, in the middle of his body." ${ }^{, 253}$ Sor María Ignacio del Niño Jesús, who professed in the Franciscan convent of Santa Clara de Jesús, Queretaro, in the late eighteenth century, also describes a visual encounter with the devil. In a letter to her confessor dated February 20, 1802, she writes that she saw the devil standing behind a novice she has just counseled. Taken by a sudden urge to evacuate, she is brought a chamber pot which breaks in pieces under her weight and narrowly misses cutting her. ${ }^{254}$ As in this case, many of these confessional accounts of tortures by demons and the devil were highly charged with sensory and sometimes sensual detail. The body of the nun became a war zone where all senses were under attack alternately described in terms of violence and arousal. ${ }^{255}$ All the body's faculties were vulnerable to exploitation: sight,

${ }^{252}$ Here the nun clearly means her soul was protected. María de San José, "Vida,” vol. 8.53-55r. Cited in Myers and Powell, Wild Country, 212.

${ }^{253}$ Ibid.

${ }^{254}$ María Ignacio del Niño Jesús. "Carta 41, Febrero 20 1802.” Selected and transcribed by Ellen Gunnarsdottir, as cited in Lavrin and Loreto, ed. Diálogos espirituales, 381-82.

${ }^{255}$ Sluhovsky aptly notes that monastic carnality and a modern understanding of sexuality cannot be equated. This does not mean that the modern "purifies" or desexualizes carnality into spirituality. Sluhovsky writes: "Spirituality, sensuality, and sexuality coexisted in early modern mysticism and possession in ways that were more complex and more multidimensional than twentieth-century thinkers assumed," 1400 . 
sound, smell, taste, touch. In the obligatory progress towards "likeness" to God, all had to be purified through confession and penance. ${ }^{256}$ María de San José, for example, complained that she was tormented with always seeing devils naked -- that during nine years she felt their torments ceaselessly at all hours of the day and night. ${ }^{257}$

To her advantage, María de Jesús Felipa received celestial support to counteract these invasions by her enemies. Her two guardian angels (custodios) provided an antidote to her tormentors. She refers often to the caricias (caresses) of these heavenly visitors -their pats and strokes. In contrast to the demons, they speak to her with respect, always addressing her as "vosotros" and "vos:" the formal "you" reserved for clergy, royalty and dignitaries. They bring tidings of divine approval. "Do not be misled, Madam. Your Beloved says that He loves you as Himself," they tell her. ${ }^{258}$ Sometimes they interpret the visions for her. In January, for example, they tell her that two entwined flaming hearts she envisions are hers and her Mother Superior's. This apparition is God's approval of her ascetic practices. She should feel no shame for their disrobing and whipping each other. ${ }^{259}$ In her diary entry for March, Sor María writes that sermons and preachers are all

${ }^{256}$ Rosalva Loreto López, "La sensibilidad y el cuerpo en el imaginario de las monjas poblanas del siglo XVII," Memoria del II Congreso Internacional, 541-55.

${ }^{257}$ María de San José, “Vida,” vol. 8.53-55v, as cited in Myers and Powell, 212-13.

258 "No os confundáis Señora [. . .] dice vuestro amado que os ama como a sí mismo ...” AHPFM María de Jesús Felipa, Diary, 88v.

${ }^{259}$ Ibid., 16, 16v. Months later, Sor María is visited by a demon who agrees that she should not be held accountable for the practice in which the two have been engaged, but for a different reason. "They have had you stop the mortifications and exercises you and the other one were conducting because it is unworthy and abhorrent to God to punish yourself in this way. You broke the vow of chastity and if, in you, that is bad, it is an even greater reproof of the ministers of the Lord because it is their job to teach purity and decency in penitential practices. You disrobed dishonestly. You have no shame or respect for God, who sees all, nor for his Saints nor for the Devil.... Tell me what pleasure it gave you to be mistreated and tormented and how you wished all did the same." Ibid., 132-132v. See Appendix A (41). 
very well and good, but that being a woman -- incapable and very ignorant -- she learns more from her guardian angels; that she feels greatly enlightened and well served in her task by their presence -- alone in her cell setting quill to paper. ${ }^{260}$

These supporters watched over her as she wrote. In August, they tell her that, of all the brides of Christ, she has been given the importance (valor) to speak His truth. ${ }^{261}$ Occasionally, her guards speak specifically against the demons, referring to their impediment to her writing as a scourge. "Know that even if you wasted all the paper in the world writing what you have been commanded," they tell her:

You would have nothing to repent. . thus, with the sweat of your brow, you save the heart of many souls. ... [You are]writing His Majesty in the whiteness and purity of your soul and voice, translating on paper what is much to His pleasure -- in that way, performing your religious vows of obedience, poverty, chastity and enclosure. ${ }^{262}$

Her guardian angels reinterpret the meaning of her writing as fulfilling her vocation as a professed nun. On St. Augustine's Day, after a rigorous session of self-inflicted corporal punishment, she is told by her guardians to leave off her humbling prostrations: "Blindly" follow your superiors' orders. "Writing time is short," they caution. ${ }^{263}$

Sometimes her guardians act as acolytes to God. In June, on the Feast of Corpus Christi, Sor María writes that her divine Husband is present in her soul, adorned in "rich raiment" (ricas vestiduras) and that her custodians, by order from the Supreme King, dress her in a gown of the same cloth more resplendent than the sun reflected in a glass.

\footnotetext{
${ }^{260}$ Ibid., 32. See Appendix A (42).

${ }^{261}$ Ibid., 92v. "de todas sus esposas que en vos les pone el valor que comunica a las cosas."

${ }^{262}$ Ibid., 27v-28. See Appendix A (43).

${ }^{263}$ Ibid., 103, 103v. "Levantaos de tan humilde postura. . . Obedeced ciegamente a vuestros superiores ... Tiempo es ya de que abreviéis el escrito."
} 
Placed on a throne, she is given a chain to which other chains are attached. Sor María and her Lord pull on the chain to which were attached many hearts in which the Blessed Sacrament shines. Christ tells her:

Look! These are the hearts of infidels: some are sinners, some are the just who have secretly received succor for the needs, others relief from temptations, others tranquility for their troubled consciences. ... But while you wear the rude habit of the flesh, it behooves you to look to the mortals. Do not forget the infidels and the barbarous nations. As you care for mine; I will take care of yours. ${ }^{264}$

In addition to visitations from her two angels, Sor María had sixteen encounters with direct emanations of the Divine. Some of these events included visions and transport to another setting. In some, as in the one described above, the vision is interpreted. All encounters, however, are recorded as half of extended dialogues or, better stated, speechified responses to the nun's self-doubts. In two such tableaux, Sor María sees an image of her Husband (Jesus Christ) in a lake of blood. In March, He carries the cross, but cannot walk for its heaviness. Blood pours from all his pores, creating great byways (avenidas). In response, Sor María takes up her quill to relieve his pain. He tells her:

That is what I want of all my children -- that they follow my path, those in whom I am well pleased should fear neither death nor anguish nor persecution nor the devil nor temptation because in following my footsteps, every load is light, all pain is lessened, torment ceases, the tempest subsides. ${ }^{265}$

Sor María writes that upon receiving such tender words, she was given to understand that her writing was to the liking of Christ. She received divine authorization: her

\footnotetext{
${ }^{264}$ Ibid., 72v, 73. See Appendix A (44).

${ }^{265}$ Ibid., 33v. See Appendix A (45).
} 
"authorship" was recognized. Writing is such an effort, but even if she were to have died in the process she would have found the life she desires. ${ }^{266}$

Blood is the salient feature in these heavenly visions. In August, Sor María again is presented with an image of Christ in a lake of blood. In this instance, he tells her: "Bathe yourself in these waters, my daughter -- who I call my wife. Drink of these currents. Take comfort and rest. I have already spilled my nourishing blood."267 In September, the relation between Sor María's witness, the Passion and the sacrament of Communion is more explicit. Though no image is present, Christ tells her: "You will be a light if you shine it (for those who) go looking for me. Take; eat the delicacies of my body and blood. Drink the wine of my love and go in peace." ${ }^{268}$ Blood is represented as a salient feature in Sor María's vocation as intercessor. In May 1751, she goes through a wretched period during which time she does penance and prays for two persons in the convent who have fallen ill: the chaplain and a young woman named Rosalie. ${ }^{269}$ When she prays that they be spared, Jesus tells her that all is assured. "Give me your heart," he orders. Taking it, he writes his name on it, dipping the "instrument" into the blood from the wound in his side. Sor María is not content until he also writes it on the heart of the

${ }^{266}$ Ibid., 34. "Me daba de entender que lo que yo escribía era de su agrado aunque como dejo dicho que me hallaba libre de lo que sentía de agonías, escribiendo me servía de tanto esfuerzo esto que aunque me hubiera muerto, me hubiera hallado la vida que deseo."

${ }^{267}$ Ibid., 100v. Se me representaba mi divino esposo todo hecho mares de sangre y me decía: "Llora hija, llamada esposa mía y báñate en estos mares, bebe de estas corrientes y confórtate que porque tú descanses. Ya vertí mi sangre gustosa."

${ }^{268}$ Ibid., 117. "Serás lucidísima antorcha si la presente por andar buscándome . . Toma. Come de los manjares de mi cuerpo y sangre. Bebe del vino de mi amor y camina en paz." Felipa prefaces these words as if they came to her in a reverie with her guardian angels playing instruments as a kind of "background music."

${ }^{269}$ Rosalia was a protegée of Sor María. She may have been one of her students from the community, a novice or one of the servants in the convent. 
ailing person. Jesus says: "It is already written in the Book of the Blessed. Be assured that you are his sponsor and I will not let him perish.",270

Sor María's encounters with God in his person as Father and as Jesus Christ are the most visually complex of the supernatural events she includes in her record. In May 1751, much in distress over the illness of the convent chaplain, she received a salutary visit from her patron saint, Philip, who interceded for her with God. "I love the wives of my son," God said, "and so that you see how faithful I am to you, beloved of the most high and omnipotent arm [Jesus Christ], I come to console you and strengthen your spirits for what is to come." ${ }^{271}$ Having received comfort from these and other words, Sor María then sees waters spring from God's heart into her own and flow onto the earth bringing forth flowers, reviving dead plants, rocks, fruits and trees, sweeping away large, ugly animals and bewildered small creatures. She hears the beating of the waters and, wondering where the animals have gone, she makes out the creatures hiding among the many "voices" of the earth. ${ }^{272}$ She sees her guardian angels walking along whipping the animals. Different species of birds take flight, different settings present themselves to Sor María, who now both observes the landscape in her physical person and is a part of it spiritually. Her "soul" and her custodians move to the center of the earth and open doors so that "many souls like lightning bolts" spring forth. Her patron saint interprets the event for her: "I and all who are devoted to you know that the Lord is exalted and made known by laying claim to you through his love. Through the grace of my intercession today you

${ }^{270}$ Ibid., 63v. See Appendix A (46).

${ }^{271}$ Ibid., 59v. See Appendix A (47).

${ }^{272}$ It is not unusual for the nun to confuse and mix faculties in an attempt to describe the sensations she experiences when she talks about the supernatural encounters. 
have been able to see, not so you forget but rather are strengthened in all the work you have yet to come."273

Her spiritual interlocutor explicates this allegory textually. Each piece of the picture -- the rocks, the whips, the birds -- stands for something in this allegorical tableau. The beautiful gardens are "the religions" that Sor María must enlighten with God's light. The birds are the "blessed" flying to heaven; they are the souls to be released from purgatory on whose behalf she takes Communion. The vision concludes with the baby Jesus placed in her arms. The guardian angels open a cape on which is written her name "Felipa de Jesús" and the names of her family of origin. The infant Christ then tells her: "I will give you to my eternal Father because you possess the manner and merits of Jesus, Mary and Joseph." Sor María concludes: "I don’t know how this came to be except that it led me to believe that my end was near and that these works were the last with which I would console myself, not because they had to be, but rather because I saw myself in such a different way from how I had in similar instances. ${ }^{274}$ In all these visions, where God as Father, Christ the Redeemer or Infant Jesus appear and speak to Sor María, the voice is authoritative and empowering of her position as foremost among His brides.

Sor María received additional visions that present her with settings and actions that her spiritual guides interpret for her. In one, she is a little bird in a pasture full of sheep. The pastor is transformed from shepherd in rustic clothes to priest in white vestments with a set of keys in his hand. ${ }^{275}$ Twice Jesus takes her to a beautiful garden.

\footnotetext{
${ }^{273}$ Ibid., 60, 60v, 61. See Appendix A (48).

${ }^{274}$ Ibid., 61v. See Appendix A (49).

275 This image underscores the "key" role played by the priest is accessing the kingdom.
} 
“There's nothing sweeter than suffering," he tells her. He talks about his own hours of abandonment. "You were one of the souls that comforted me in my greatest hour of need," he says. ${ }^{276}$

Sor María's encounters with the spiritual world, particularly those involving God, can rightly be considered "visionary" in that they are events with words that convey that more than one sense is involved. Their descriptions are visual, auditory, olfactory, and tactile. Sor María finds herself in different places -- a deep hole, a pasture, a garden -- and transported to a different dimension where actions and objects take on allegorical importance. She describes her state of animation as altered -- suspended, downshifted, filled with "lights," and as if she and the Lord were "alone in the world."277

Sor María's visions are markedly different from those of Teresa of Avila. The descriptions of her inner state lack the clarity of Teresa's. Nor is there any indication that she is familiar with the literature of the Reformed Carmelite tradition brought from Spain. ${ }^{278}$ Teresa wrote carefully and extensively about her visionary experience in Libro de la Vida. In a particularly striking passage she describes Jesus Christ as always present at her side, but she specifies that his presence is not an imaginative vision, i.e., she

\footnotetext{
${ }^{276}$ The garden setting recalls his abandonment by his disciples in Gethsemane who slept rather than keeping watch with him. Ibid., 99, 119v, 120v, 123v, 131, 143. Transcriptions for the two passages quoted here are: fol. 119v.: "No tiene más gozo que en el padecer;" and fol. 120v.: "tú fuiste una de las almas que me causaron alivio y confortación en mi mayor desconsuelo."

${ }^{277}$ Ibid., 100, 99.

${ }^{278}$ Electa Arenal and Stacey Schlau emphasize the impact of Teresa of Avila on the lives and writing of Hispanic nuns who came after. The fact she was canonized forty years after her death made her a model to emulate. In effect, the record of her visionary experiences authorized the extension of the confessional tradition to encourage the spiritual biographies of others. See Arenal and Schlau, "Stratagems of the Strong, Stratagems of the Weak," 38.
} 
receives no image of it. She does not see any form, yet he is a witness of everything she

does. He is impossible to ignore. She tells her confessor:

In this vision it is seen clearly that Jesus Christ, son of the Virgin, is present. In the prayer of union or quiet some impressions of the Divinity are bestowed; [by way of contrast] in the vision, along with the impressions, you see that also the most sacred humanity accompanies us and desires to grant us favors. Then the confessor asked me, "Who said it was Jesus Christ?" "He told me many times," I answered. But before He told me He impressed upon my intellect that it was He, and before doing this latter He told me he was present -- but I didn't see Him. ${ }^{279}$

To clarify, Teresa provides an analogy:

If a person whom I had never seen but only heard of should come to speak to me while I was blind or in the pitch dark and tells me who he was, I would believe it; but I wouldn't be able to assert as strongly that it was the person as I would if I saw him. In the case of this vision, I would; for, without being seen, it is impressed with such clear knowledge that I don't think it can be doubted. ${ }^{280}$

Clearly, the saint negotiated within the limitations of language to communicate her experience of the Divine presence. At the same time, she deftly delineated different types of visionary experience, making clear that hers were incorporeal.

María de San José, who also struggled with how to describe such experiences, demonstrates familiarity with Teresa's work and the controversy it excited when she clarifies that God comes to her on His own initiative, but that she provides the state of reception for him. She writes:

I found myself in that prayer of which I have already spoken. This happened without my doing anything on my part, but simply because the Lord was pleased to grant me this favor of such great worth. The Lord

\footnotetext{
${ }^{279}$ Teresa of Avila, "Life," 27.3, The Collected Works, vol. 1, 174.

${ }^{280}$ Teresa of Avila, 27.4-5, 175.
} 
gives this manner of prayer when He wishes and as He wishes, and as I understand it, it is the prayer of quiet. ${ }^{281}$

For María de San José, these opportunities to "see" spiritually often came in and around receiving Communion, as on one Saturday evening during Passion Week, the evening prior to Palm Sunday. She writes that no sooner had she received the host -- "with His Majesty still in my mouth"-- that God spoke to her saying: "Here I am in your breast.,"282 The description is arresting in the juxtaposition it makes between a corporeal representation of Christ in the communion wafer and an oral communication that locates His presence in her interior.

Teresa marked a distinction between a mystical union with God and the visionary experience. Visions were possible, but not necessary building blocks in the soul's journey. Her mystical doctrine was rooted in her presumption that the end and fulfillment of the Christian life was the union of the soul with God. Her Camino de perfección was a way to arrive at sanctity by imitating the desert hermits who inspired the Carmelite rule. Recogimiento could be arrived at through mental prayer, but there was nothing in her writings that says it must. ${ }^{283}$

In the case of María de Jesús Felipa, imitatio Christi played a much larger part in her path to perfection. Nowhere in the diary of 1751 did Sor María indicate that she was on a pathway through mental prayer to a final union with God. The word recogimiento

${ }^{281}$ María de San José, vol. 9, fol. 23v, as cited in Myers and Powell, 188.

${ }^{282}$ María de San José, vol. 6, fol.77v, as transcribed and translated in Myers and Powell, 199.

283 Gillian T. W. Ahlgren, Teresa de Avila and the Politics of Sanctity (Ithaca: Cornell University Press, 1996), 132. 
(spiritual focus) was not a part of her vocabulary. ${ }^{284}$ Nor did she indicate that a

transcendent experience allowed her to intuit the nature of the Creator in a way she could not describe. ${ }^{285}$

These characteristics made her visionary descriptions similar to other nuns who left spiritual records during the colonial period in New Spain, notably María Magdalena Lorravaquio. She professed in 1590 in the convent of San Jerónimo in Mexico City, leaving an 81-page manuscript that was copied (and perhaps redacted) by her nephew Francisco de Lorravaquio in 1650 , one hundred years prior to the journal left by Sor María. ${ }^{286}$ The account is divided into three sections: personal history, daily life in the convent and a record of the examinations her confessors subjected her to in order to discover if her visions were authentic or simply tricks by the devil. Unlike Sor María, María Magdalena explains the experience of being in a meditative, receptive state (recogimiento) prior to receiving a vision. Although her first vision came as the result of an unpleasant mortification she experienced as a novice, her succeeding visions -- many

284 "Recogimiento" or a solitary meditative state, was a term much used by Teresa in her description of the stages by which one progresses in his or her path to perfection. Las Moradas (The Interior Castle), which describes the six stages of mental prayer, received careful scrutiny from her theological critics. Most prominent was Alonso de la Fuente, who said that the third and fourth degrees sounded more like dexamiento than recogimiento. "Dexamiento" (abandonment), a term used to condemn the alumbrados, was considered heretical. "This prayer of quiet is the work of God alone, in which man must be passive, leaving the faculties half-lost in a sort of sleep," Alonso wrote, as cited in Ahlgren, 123.

${ }^{285}$ For a broader understanding of the history of mysticism, see "Mysticism" (definition) in The New Dictionary of Catholic Spirituality, Michael Downey, ed. (Collegeville: The Liturgical Press, 1993), 681-92, and Evelyn Underhill, Mysticism (New York: Doubleday, 1990).

${ }^{286}$ As noted by Asunción Lavrin, the spiritual writings left by María Magdalena Lorravaquio, María de Jesús Felipa, María de San José and others were all written in obedience to an order from a superior: their confessor, a bishop or other member of the clergy. Sor Juana Inés de la Cruz (1648-1695), who like María Magdalena also professed in San Jerónimo, was an exception. She did not write under obedience to the mandate from a priest, but in response to the creativity and intellectuality that her faith inspired in her. See Lavrin, “La Madre María Magdalena Lorravaquio y su mundo visionario.” Signos Históricos, 7.3 (enero-junio 2005), 26. 
of which suspended her into a somnambulant state for days -- seem to associate with her prayer life. ${ }^{287}$ Her familiarity with the writings of Teresa is evident, in that she enters into a visionary episode by meditatively collecting herself. As with María de San José, taking Communion also seems to promote visioning.

Additionally, María Magdalena uses some of the same metaphors as Teresa in describing her state of being. ${ }^{288}$ In her writing, Teresa made clear that her visions were spiritual rather than corporeal: that she saw with the eyes of her soul much better than with the eyes of her body. Of all her senses, María Magdalena also gives primacy to visual imagination, although she admits at times that she see with the eyes of her body. ${ }^{289}$

Like Sor María and others, she meditated on the wound in Christ's bleeding side (where the centurion stuck his sword). Whereas in one of Sor María's visions, Jesus places a writing instrument in his own side to write his name on her heart, María Magdalena wishes to deposit her soul within his side. Both María Magdalena and Sor María recorded visions involving other nuns. For María Magdalena the distress of seeing another nun in pain put her into a suspended state for a matter of days. ${ }^{290}$ For Sor María also, the experience was painful. Transported to another place, she is encircled by ugly

${ }^{287}$ Ibid., 29. María Magdalena Lorravaquio was no alien to pain, however, but it was not selfimposed, as is the case with Sor María de Jesús Felipa. She lived for years as an invalid or semi-invalid due to primitive and brutally painful medical treatments.

${ }^{288}$ María Magdalena Lorravaquio, Libro de su vida, 13: “And it would be impossible to make clear how at times I feel or is communicated to my soul the greatness of His Majesty; I can only say that I enter his wine cellar [an image also used by Teresa] and am intoxicated I know not how," as cited in Lavrin, Signos, 31. (Translation is mine.)

${ }^{289}$ María Magdalena, 47. "On another occasion, being at prayer in contemplation of Christ's Passion, (she) saw very distinctly with earthly eyes the host of Christ crucified in human flesh and his holy body very bloody," as cited in Lavrin, Signos, 33.

${ }^{290}$ María Magdalena Lorravaquio, Libro de su vida, 46v, 49v, 61v, as noted in Lavrin, Signos, 39. 
figures that wound themselves, blaspheme God and the Virgin, dance and sing

licentiously. They pay Sor María no mind, but rather beat, spit on, and trip up another member of her community. The nun who is mistreated bears it all with grace; Sor María, who observes it, is in agony. ${ }^{291}$

Visions recorded by both María Magdalena and Sor María abound with visual detail: water is crystalline, clothing is sumptuous and gardens are verdant. As Kristine Ibsen writes, the affective impact of vision apparent in all these writings is an outgrowth of the rigorous spiritual exercises pioneered by Ignatius of Loyola. ${ }^{292}$ Self-examination turned the eyes inward, released the imagination to pursue visual reflection. Not all of the confessors of these nuns were Jesuits, but many were, and the Jesuit tradition transformed meditation into a powerful visual force. Baroque art of the period focused on the Passion of Christ, the hours and days leading to his crucifixion. In Chapter 29 of Libro de la Vida, Teresa provides a summary of her visions:

The Lord almost always showed Himself to me risen, also when He appeared in the Host -- except at times when he showed me His wounds in order to encourage me when I was suffering tribulation. Sometimes $\mathrm{He}$ appeared on the cross or in the garden and a few times with the crown of thorns; sometimes He also appeared carrying the cross. ${ }^{293}$

Her list of tableaux reads like an inventory of favorite baroque paintings that record the events of Holy Week: Jesus in the Garden of Gethsemane, bearing the cross to Golgotha, hanging from the cross, wearing the crown of thorns and revealing the wounds in his side.

\footnotetext{
${ }^{291}$ AHPFM, María de Jesús Felipa, Diary, 140v, 141.

${ }^{292}$ Ibsen, "The Hiding Places of My Power," 256.

${ }^{293}$ Teresa of Avila, "Life," 29.4, 190.
} 
The emphasis of baroque art on the Passion of Christ promoted visionary images of bloody suffering. Interesting in the case of the nun studied here, however, Sor María restages the Passion to fit her circumstance: Christ carries a cross through a lake of his own blood in one, just at a time when she feels so ill that there is talk of "bleeding" her. ${ }^{294}$ She hands him her heart and he writes his name upon it with the blood from his side, at a point when two people close to her are seriously ill. ${ }^{295}$ Sor María enters Christ's Passion when her life is most painful. When she is drawn into a prophetic vision, the reference points are to more pacific episodes in his life story. In each she receives a commission. In one she is adorned with the same brilliant attired as her groom's, in a second one, she joins him in a pasture full of sheep, in a third, she receives him as an infant in her lap.

As a visionary, Sor María experienced occasional ecstatic states. She established bonds with the Divine and other entities from the spiritual world using the sensory language at hand. Through these contacts she pursued her own salvation and that of those in her charge, most notably those within her own community and the souls in purgatory. ${ }^{296}$ These encounters propelled Sor María into different frames of time and space -- moving her into the past and the future and transporting her to bucolic and horrific locations, all the while tying these visions to her life and her relationships within the convent.

${ }^{294}$ AHPFM, Sor María de Jesús Felipa, Diary, 33, 24.

${ }^{295}$ Ibid., $63 \mathrm{v}$.

${ }^{296}$ This seems to be an explicit charge for nuns of the period, appearing frequently in their writings in colonial America. 


\section{CONCLUSION}

María de Jesús Felipa's diary of 1751 shares many characteristics with the other first-person accounts by early modern nuns in Spain and the Americas that have been studied by scholars in the last two decades. Attributes that distinguish it, however, raise questions on how best to categorize it, as well as present a number of avenues for further study.

As argued by this thesis, though often difficult and at times unpleasant, keeping a spiritual journal was, for Sor María, an opportunity for self-expression and self-discovery on her journey toward spiritual fulfillment. Through her journal entries she examined her inner life, defended her vocational convictions and engaged in spiritual teaching by embedding theological statements within her visions. ${ }^{297}$ She fully invested her physical, emotional, spiritual and intellectual energy in producing a document that reflected the issues that most preoccupied her attention, linking her worldly duties, events and relationships to her spiritual calling in an attempt to make sense of the voices and visions that presented themselves to her.

Evidence that she focused and edited her reflections is apparent in that monthly installments were, the author admits, submitted out of sequence, giving her the opportunity to insert reference to later events, such as the meeting with Don Pedro, into earlier records. The sense of incompleteness and confusion that triggered her tardiness in turning over her copybooks to her confessor argues for her desire to give form to and make sense of her life through her writing. Sor María, then, is both narrator and

\footnotetext{
${ }^{297}$ As noted by Moshe Sluhovsky: "nuns lived in a small world where meditation and resistance to temptation were primary occupations. ... Wishing for God but most likely encountering the Devil, nuns were regularly examining their inner lives and finding them short of their aspirations." Sluhovsky, 1411.
} 
protagonist: she plays the starring role in the events she records. Self-reflection is a major part of her preoccupations. Her entries include frequent examination of her thoughtprocesses and motives, as well as an occasional character analysis. The variety of voices she adopts reflects both an attempt to shape the finished product and to authenticate its veracity. She uses the circuitous grammatical constructions and repetitive descriptions characteristic of the baroque conventions and secondary orality discussed in Chapter 2 for ruminative musings, but when she cites conversations between her Mother Superior, her Chaplain and her confessor, the language is straightforward, the sentences short and their purposes clear. Her long citations from the spirit world vary according to her visitor. Sor María's demons are disrespectful and sardonic; her custodians, warm; and God and Jesus Christ, and her saintly visitors, authoritative.

As presented in Chapters 3 and 4, Sor María's record differs from a number of other diaries and spiritual biographies of the period. Nor does it bear resemblance to patterns established by the spiritual records of late medieval or other early modern saints. ${ }^{298}$ Only two instances, a passing reference to Rosa -- presumably St. Rose of Lima -- and Mother Agreda -- María de Jesús de Agreda, the Spanish author of Mystica Ciudad de Dios -- indicate any point of contact with precedents. In neither case is spiritual writing mentioned. Also, Sor María's diary is markedly different from many other accounts in the immediacy of the events it records. These descriptions, both within the real time of the convent and the spiritual time of her visions, take place within days of having occurred. In a chronological sense, hers is the closest we come to an eye-witness

\footnotetext{
${ }^{298}$ María de San José's autobiographical journal, as translated and edited by Kathleen A. Myers and Amanda Powell, for example, and even Teresa de Avila's Libro de la Vida, follow patterns established by tradition. In the case of María de San José whole passages are "lifted" from other works. See Chapter 4.
} 
account. In these instances, the events -- such as the castigation of her demons or the advice she gives to her Mother Superior -- are laid down without the intervening hindsight of interpretation. ${ }^{299}$

Is the journal of 1751 a spiritual autobiography or is it something else? Categorizing such a work as her diary and how it relates to the Spanish visionary tradition transplanted in the New World is not the easiest of tasks. In "Crossing Boundaries: Defining the Field of Female Religious Writing in Colonial Latin America," Kathleen Ann Myers examines the general developments of the study of "convent writing" since its earliest beginnings in the mid-1980s. ${ }^{300}$ Important to Myers' observations is the recognition that scholars moving into the field of religious writing did so against a background of two concurrent research movements: "broad acceptance of new historicism and the rise of cultural studies -- both of which looked specifically at 'low' as well as 'high' cultural production and sought to include the worldview of the people studied." ${ }^{301}$ Thus, study of a document like Sor María’s diary of 1751 becomes part of a new tradition, i.e., the discovery of previously voiceless authors and their analysis in the context of their culture. ${ }^{302}$ Taking this point a bit further, then, just as Sor María’s "text" cannot be severed from her "context," she could not disengage her visionary experiences from the day-to-day life within the convent. Apparently, although

${ }^{299}$ See AHPFM, Sor María de Jesús Felipa, Diary, 86v. for an example of a diatribe by demons. See Ibid., 11v-112v. for Sor María's advice to the Mother Superior.

\footnotetext{
${ }^{300}$ Kathleen A. Myers, “Crossing Boundaries,” 151-65.

${ }^{301}$ Myers, 152.

${ }^{302}$ Ibid., 153.
} 
her inclusion of convent business was a sticking point with her confessor, it was often the cares of her daily life that her demons and guardian angels took up in her visions. Indeed, it is the close relationship in content of the spiritual visions and worldly matters that dictated the conventions of Sor María's record. As an unmediated, unscripted journal, it perhaps more comfortably occupies the subgenre cuenta de conciencia (personal diary) than vida spiritual (spiritual biography). ${ }^{303}$

Issues raised by Sor María's diary of 1751 present a number of avenues for further research. Foremost is, of course, corroborating her presence in the convent of San Juan de la Penitencia during the time period in which the journal was kept. ${ }^{304}$ Records for San Juan de la Penitencia have not been fully exploited, but doing so may be a difficult task, since the convent was destroyed and its records are scattered or nonexistent. The convent was founded without a benefactor, poorly endowed and unique in that it was constructed in an area populated by Indians. However, a further study of this convent could prove interesting for an additional reason. Records of church authorities throughout its existence indicate management problems and inquisitional concerns. ${ }^{305}$ The presence of Sebastiana Josepha de la Santísima Trinidad, another nun noted for her adherence to self-punishing penitential behavior, at the same time as María de Jesús Felipa also raises administrative issues. $^{306}$

\footnotetext{
${ }^{303}$ Myers cautions how often scholars read these early modern writings according to present day ideas about autobiography and journal-keeping, without taking into consideration period distinctions between these subgenres. Ibid, 158.

${ }^{304}$ See Appendix B for a list of persons named in the diary.

${ }^{305}$ In Brides of Christ, Lavrin cites several.

306 "What was going on at that convent?" Lavrin wrote me in an e-mail, after she had perused some of the early chapters of Sor María's diary of 1751.
} 
A second avenue worthy of pursuit relates to Sor María's frequent references to "leaving the convent," something presumed to be impossible once a nun professed. Enclosure was one of the vows that a nun made upon entering the life, and Sor María records renewing her vows on two occasions during the year the journal was kept. Were these just indications that she questioned her vocation? Inquisitional records indicate that errant nuns, even those who were excommunicated, stayed within the physical confines of the cloister. I am unsure how one would go about testing the premise that once a nun, always a nun in mid-eighteenth century New Spain. Is it possible that there was a loosening of such restrictions during this time period?

Finally, the diary raises questions about the operations of the Inquisition in the eighteenth century. Was its existence anything more than a paper tiger at this point in the history of New Spain? Sor María makes frequent references to the Santo Oficio. She is alternately hoping for and dreading a review of her writing by the court and was told that her copybooks were in its possession. A long passage in the diary entry for September concerns how she would conduct herself should her confessor be brought before the court. The jurisdiction of the institution was vast, stretching from Mexico City north into what is now California, Arizona, New Mexico and Texas and south throughout Central America to Panama. It was overburdened with paperwork and understaffed. Its focus had shifted from concerns over orthodoxy to routing out sexual improprieties within the monasteries and monitoring the political loyalty of the clergy. ${ }^{307}$ Although Richard E. Greenleaf, Mary Elizabeth Perry and Anne J. Cruz have discussed the cultural impact of

${ }^{307}$ See Ruth Behar's article in the American Ethnologist (cited earlier) for this shift and as a starting point for research into the workings of the Inquisition in the eighteenth century. 
the Inquisition in New Spain during the sixteenth and seventeenth centuries, research on its activities during the eighteenth century seems to be limited.

These yet-to-be-pursued issues aside, a close reading of the diary of 1751 effectively reveals María de Jesús Felipa as author of her own life story. The document provides an intriguing portrait of an individual nun and her struggle to make meaning of her mission in the world. At the same time her first-person account reflects the culture of conventual Christianity in the late colonial vice-regal period, the impact of postTridentine reforms and difficulties in the governance of convents in the far-flung Spanish empire. Although difficult, writing provided Sor Maria with an opportunity to establish her integrity, exercise control, and justify her thoughts and actions as she charted her path to perfection. Writing under the supervision of a confessor, María de Jesús Felipa was her own person. In its organization and focus, her diary resolutely records her struggle for self-determination within the limits imposed by the monastic vows of obedience, chastity, poverty and enclosure. 


\section{REFERENCES}

Primary Sources

Augustine, Bishop of Hippo. Confessions, ed. William Watts and W.H. D. Rouse. New York: Macmillan, 1912.

Anonymous [Sor María de Jesús Felipa]. Cuaderno manuscrito anónimo, sin título. Archivo Histórico Provincial Franciscano de Michoacán, Celaya: sección manuscritos varios, 5.9.

Anonymous [Sor María de Jesús Felipa]. Manuscript Diary of a Mexican Religious. U.S. Library of Congress, Feb. - Dec. 1758.Washington D. C.: Manuscript Division MM59.

Cortés, Hernán. Cartas de relación. Mexico: Editorial Porrúa, 1979.

Ignacio de Loyola. Obras, ed. Ignacio Iparraguirre, Cándido de Dalmases y Manuel Ruíz Jurado, 6th ed. Madrid: B.A.C., 1997.

Sigüenza y Góngora, Carlos de. Parayso Occidental plantado y cultivado por la liberal benéfica mano de los muy católicos y poderosos reyes de España nuestros señores en su magnífico real convento de Jesús María de México. Mexico: UNAM-Condumex, 1995 [1684].

Teresa de Jesús. Su Vida. Buenos Aires: Espasa-Calpe Argentina, S. A., 1951.

\section{Secondary Sources}

Articles

Ahlgren, Gillian T. W. "Visions and Rhetorical Strategy in the Letters of Hildegard of Bingen." In Dear Sister: Medieval Women and the Epistolary Genre, ed. Karen Cherewatuk and Ulrike Wiethaus. Philadelphia: University of Pennsylvania Press, 1993, 46-63.

Arenal, Electa and Stacey Schlau. "Stratagems of the Strong, Stratagems of the Weak: Autobiographical Prose of the Seventeenth-Century Hispanic Convent Author(s)." Tulsa Studies in Women's Literature. Vol. 9, No. 1 (Spring, 1990): 25-42.

Atkinson, Clarissa. "Precious Balsam in a Fragile Glass: The Ideology of Virginity in the 
Later Middle Ages.” Journal of Family History (Summer, 1983): 131-43.

Beckwith, Sarah. "A Very Material Mysticism: The Medieval Mysticism of Margery Kempe, In Medieval Literature: Criticism, Ideology and History, ed. David Aers. Brighton: The Harvester Press, 1986, 34-57.

Behar, Ruth. "Sex and Sin, Witchcraft and the Devil in Late-Colonial Mexico," American Ethnologist 14 (1987): 34-54.

Bilinkoff, Jodi. "Navigating the Waves (of Devotion): Toward a Gendered Analysis of Early Modern Catholicism." In Crossing Boundaries. Attending to Early Modern Women, ed. Jane Donawerth and Adele Seef. Newark: University of Delaware Press, 2000, 161-172.

Coakley, John. "Gender and the Authority of Friars: The Significance of Holy Women For Thirteenth-Century Franciscans and Dominicans." Church History 60.4 (December 1991): 445-460.

Donahue, Darcy. "Writing Lives: Nuns and Confessors as Auto/Biographers in Early Modern Spain." Journal of Hispanic Philology 13.3 (Spring 1989): 230-39.

Easton, Martha. "Pain, torture and death in the Huntingon Library Legenda aurea." In Gender and Holiness: Men, women and saints in late medieval Europe, ed. Samantha J.E. Riches and Sarah Salih. London: Routledge, 2002, 49-64.

Eich, Jennifer. "Giving the Devil His Due: A Man's Place in Women's Spiritual Narratives." Confluencia 14.1 (Fall 1998): 67-81.

. "The Body as a Conventual Space of Resistence." In Mapping Colonial Spanish America. Places and Commonplaces of Identity, Culture, and Experience, ed. Santa Arias and Mariselle Meléndez. Lewisburg, PA: Bucknell University Press, 2001, 202-20.

Elliott, Dyan. "Seeing Double: Jean Gerson, the Discernment of Spirits, and Joan of Arc." American Historical Review 107. 1 (Feb. 2002): 26-54.

Fernández Peláez, Ivan. "Teresa de Jesús y el discernimiento de espíritus: Una hermenéutica de ida y vuelta." Long Beach: GEMELA Conference, Oct. 4, 2008.

Finke, Laurie A. "Mystical Bodies and the Dialogic of Vision." In Maps of Flesh and Light: The Religious Experience of Medieval Women Mystics, ed. Ulrike Wiethaus. Syracuse: Syracuse University Press, 1993, 28-44. 
Glantz, Margo. "El cuerpo monacal y sus vestiduras." Mujer y cultura en la colonia hispanoamericana, ed. Mabel Moraña. Pittsburgh: Biblioteca de América, 1996, $171-82$.

Greenleaf, Richard E. "Mutilation and Meaning." In The Body in Parts: Fantasies of Corporeality in Early Modern Europe, ed. David Hillman and Carlo Mazzio. New York: Routledge, 1997, 221-42.

Gunnarsdottir, Ellen. "The Convent of Santa Clara, the Elite and Social Change in Eighteenth Century Querétaro." Journal of Latin American Studies 33.2 (May 2001): 257-90

. "Los misioneros franciscanos y sus hijas espirituales en el Nuevo mundo. El caso de Querétaro, 1674-1810." Studie Materali di Sotria de la Religioni 68.26 (2002): 363-77.

. "Una visionaria barroca de la provincia Mexicana: Francisca de Los Ángeles (1674-1744)." In Mojas y beatas. La escritura femenina en la espiritualidad barroca novohispana. Siglos XVII y XVIII, ed. Asunción Lavrin and Rosalva Loreto López. Mexico: Archivo General de la Nación/ Universidad de las Américas, 2002, 205-62.

Hayles, Katherine. "Chaos as Orederly Disorder." New Literary History 20 (1989): 30522.

Ibsen, Kristine. "The Hiding Places of My Power: Sebastiana Josefa de la Santísima Trinidad and the Hagiographic Representation of the Body in Colonial Spanish America." Colonial Latin American Review 7.21 (December 1998): 251-70.

Laningham, Susan. "Maladies up Her Sleeve? Clerical Interpretation of a Suffering Female Body in Counter-Reformation Spain." Early Modern Women: An Interdisciplinary Journal 1 (2006): 69-97.

Larkin, Brian. "The Splendor of Worship: Baroque Catholicism, Religious Reform and Last Wills and Testaments in Eighteenth Century Mexico City." Colonial Latin American Historical Review 8.4 (Fall 1999): 405-42.

Lavrin, Asunción. "El capital eclesiástico y las élites sociales en Nueva España a fines del siglo XVIII." Mexican Studies/Estudios mexicanos 1.1 (Winter, 1985): 1-27.

"De su puño y letra: Epístolas conventuales." In Memoria del II Congreso Internacional del Monacato Femenino en el Imperio Español: Monasterios, beaterios, recogimientos y colegios, coord. Manuel Ramos Medina. Mexico: Condumex, 1995, 43-62. 
"La escritura desde un mundo oculto: Espiritualidad y anonimidad en el convento de San Juan de la Penitencia." Estudios de Historia Novohispana 22 (2000): 49-75.

- "Sor María de Jesús Felipa: Un diario espiritual de mediados del siglo XVIII (1758)." In Monjas y beatas. La escritura femenina en la espiritualidad barroca novohispana Siglos XVII y XVIII, ed. Asunción Lavrin and Loreto López, Puebla: Universidad de las Américas/Benemérita Universidad Autónima de Puebla, 2002, 111-160.

. "La Madre María Magdalena Lorravaquio y su mundo visionario." Signos Históricos 13 (Enero-Junio 2005): 22-41.

“"Sor María Marcela Soria: Una Capuchina Querétana.” In Diálogos espirituales. Letras femeninas Hispanoamericana. Siglos XVI-XIX, ed. Asunción Lavrin and Rosalva López. Puebla: Universidad de las Américas/Benemérita Universidad Autónoma de Puebla, 2006, 74-116.

."Devocionario y espiritualidad en los conventos femeninos novohispanos: Siglos XVII y XVIII.” In Historias compartidas. Religiosidad y reclusión femenina en España, Portugal y América. Siglos XV-XIX, coord. Maria Isabel Viforcos Marinas and Rosalva Loreto López. León: Universidad de León/Instituto de Ciencias Sociales y Humanidades "Alfonso Vélez Pliego" and Benemérita Universidad Autónoma de Puebla, 2007, 149-162.

"El más allá en el imaginario de las religiosas novohispanas." In Muerte y vida en el más allá. España y América, coord. Gisela von Wobeser and Enriqueta Vila. México: Universidad Nacional Autónoma de México, 2009, 181201.

Loreto López, Rosalva. "La sensibilidad y el cuerpo en el imaginario de las monjas poblanas del siglo XVII." In Memoria del II Congreso Internacional del Monacato Femenino en el Imperio Español: Monasterios, beaterios, recogimientos y colegios, coord. Manuel Ramos Medina. Mexico: Condumex, $1995,542-57$.

. "The Devil, Women, and the Body in Seventeenth-Century Puebla Convents." The Americas 59.2 (October 2002): 181-99.

"Escrito por ella misma. Vida de la Madre Francisca de la Natividad." In Monjas y beatas. La escritura femenina en la espiritualidad barroca novohispana Siglos XVII y XVIII, ed. Asunción Lavrin and Loreto López, Puebla: Universidad de las Américas/Benemérita Universidad Autónima de Puebla, 2002, 24-66. 
McNamara, JoAnn. "The Need to Give: Suffering and Female Sanctity in the Middle Ages." In Images of Sainthood in Medieval Europe, ed. Renate BlumenfeldKosinski and Timea Szell. Ithaca: Cornell University Press, 1991, 28-44.

. "The Rhetoric of Orthodoxy." In Maps of Flesh and Light: The Religious Experience of Medieval Women Mystics, ed. Ulrike Wiethaus. Syracuse: Syracuse University Press, 1993, 9-27.

Myers, Kathleen A. "Fundadora, cronista y mística, Juana Palacios Berruecos/Madre María de San José (1656-1719)." In Monjas y beatas. La escritura femenina en la espiritualidad barroca novohispana. Siglos XVII y XVIII, ed. Asunción Lavrin and Rosalva Loreto López. Puebla: Universidad de las Américas, Archivo General de la Nación, 2002, 67.

. "Crossing Boundaries: Defining the Field of Female Religious Writing in Colonial Latin America." Colonial Latin American Review Vol. 9, No. 2 (2000), 151-65.

Ramos Medina, Manuel. "La madre María Magdalena Lorravaquio y su mundo visionario.” Signos Históricos Vol. 7, No. 3 (Enero-Junio 2005), 22-41.

Sampson Vera, Elisa. "Fashioning A Cacique Nun." Gender and History 9 (1997), 191-206.

Schlau, Stacey. "Following Saint Teresa: Early Modern Women and Religious Authority." Modern Language Notes 117 (2002): 286-309.

Schons, Dorothy. "Some Obscure Points in the Life of Sor Juana Inés de la Cruz." Modern Philology 24.2 (1926): 141-62.

Schulenburg, Jane Tibbetts. "Strict Active Enclosure and Its Effects on the Female Monastic Experience ca. 500-1100. In Distant Echoes: Medieval Religious Women, vol.1. ed. J. A. Nichols and L.T. Shank. Kalamazoo: Cistercian Publications, 71, 1984, 51-86.

Scott, Joan Wallach. "Gender: A Useful Category of Historical Analysis." In Gender and the Politics of History. ed. Joan W. Scott. New York: Columbia University Press, 1988, 28-50.

Sluhovsky, Moshe. "The Devil in the Convent." The American Historical Review, 107.5 (December 2002): 1379-1411.

Weber, Alison. "Demonizing Ecstacy: Alonso de la Fuente and the Alumbrados of 
Extremadura. In The Mystical Gesture: Essays on Medieval and Early Modern Spiritual Culture in Honor of Mary E. Giles. ed. Robert Boenig. Aldershot, Hampshire: Ashgate Publishing Ltd., 2000, 141-58.

. "Gender and Mysticism." In Cambridge Companion to Christian Mysticism, ed. Amy Hollywood and Patricia Beckman. Cambridge: Cambridge University Press, 2011.

Wright, Wendy. "Inside My Body Is the Body of God: Margaret Mary Alacoque and the Tradition of Embodied Mysticism," In The Mystical Gesture: Essays on Medieval and Early Modern Spiritual Culture in Honor of Mary E. Giles. ed. Robert Boenig. Aldershot, Hampshire: Ashgate Publishing Ltd., 2000, 185-92.

$\underline{\text { Books }}$

Aers, David, ed. Medieval Literature: Criticism, Ideology and History. Brighton: The Harvester Press, 1986.

Ahlgren, Gillian T. W. Teresa de Avila and the Politics of Sanctity. Ithaca, NY: Cornell University Press, 1996.

Arias, Santa and Marisell Meléndez, eds. Mapping Colonial Spanish America: Places and Commonplaces of Identity, Culture and Experience. Lewisburg: Bucknell University Press, 2002.

Arenal, Electa and Stacy Schau. Untold Sisters: Hispanic Nuns in Their Own Works, trans. Amanda Powell. Albuquerque: University of New Mexico Press: 1989.

Arenal, Electa and Amanda Powell. The Answer = La respuesta. New York: The Feminist: City University of New York, 1994.

Arrom, Silvia. The Women of Mexico City, 1790 -1857, Stanford: Stanford University Press, 1985.

Beer, Frances. Women and Mystical Experience in the Middle Ages Woodbridge, UK: The Boydell Press, 1993.

Blumenfeld-Kosinski, Renate and Timea Szell, eds. Images of Sainthood in Medieval Europe, Ithaca, NY: Cornell University Press, 1991.

Bilinkoff, Jodi. The Avila of Saint Teresa. Religious Reform in a Sixteenth Century City, Ithaca, NY: Cornell University Press, 1989. Related Lives. Confessors and their Female Penitents (1450-1750). Ithaca, NY: Cornell University Press, 2005. 
Bireley, Robert. The Refashioning of Catholicism, 1450-1700: A Reassessment of the Counter Reformation. Washington: The Catholic University Press, 1999.

Boenig, Robert, ed. The Mystical Gesture: Essays on Medieval and Early Modern Spiritual Culture in Honor of Mary E. Giles. Aldershot, Hampshire: Ashgate Publishing Ltd., 1988.

Brading, David. Church and State in Bourbon Mexico. Cambridge: Cambridge University Press, 1994.

Burkhart, Louise M. The Slippery Earth: Nahua-Christian Moral Dialogue in Sixteenth-Century Mexico. Tucson: University of Arizona, 1989.

Buslough, John. Stephen Hawking's Universe: An Introduction to the Most Remarkable Scientists in Our Time. New York: Avon Books, 1989.

Burke, Peter. History and Social Theory. Ithaca, NY: Cornell University Press, 2005.

Burns, Kathryn. Colonial Habits: Convents and the Spiritual Economy of Cuzco Peru. Durham: Duke University Press, 1999.

Bynum, Carolyn Walker. Holy Feast and Holy Fast: The Religious Significance of Food to Medieval Women. Berkeley: University of California Press, 1987. Fragmentation and Redemption: Essays on Gender and the Human Body in Medieval Religion. New York, NY: Zone Books, 1991.

Carroll, Patrick J. Blacks in Colonial Veracruz: Race Ethnicity, and Regional Development. Austin: University of Texas Press, 1991.

Caro Baroja, Julio. Las formas complejas de la vida religiosa: Religión, sociedad y carácter en la España de los siglos XVI y XVII. Madrid: AKAL, 1978.

Casey, James. Early Modern Spain: A Social History. New York: Routledge, 1999.

Certeau, Michel de. La fábula mística: Siglo XVI-XVII. Mexico: Universidad Iberoamericana, 1993.

Chance, John. K. Race and Class in Colonial Oaxaca. Stanford: Stanford University Press, 1978.

Chowning, Margaret. Rebellious Nuns: The Troubled History of a Mexican Convent, 1752-1863. New York: Oxford University Press, 2006. 
Coakley, John. Women, Men and Spiritual Power: Female Saints and their Male Collaborators. New York: Columbia University Press, 2006.

Cope, R. Douglas. The Limits of Racial Domination: Plebian Society in Colonial Mexico City, 1660 to 1720. Madison: University of Wisconsin Press, 1994.

Downey, Michael, ed. The New Dictionary of Catholic Spirituality. Collegeville: The Liturgical Press, 1993.

Eich, Jennifer L. The Other Mexican Muse: Sor María Anna Agueda de San Ignacio (1695-1756). New Orleans: University Press of the South, 2004.

, Jeanne Gillespie, and Lucia G. Harrison, eds. Women's Voices and The Politics of the Spanish Empire: From Convent Cell to Imperial Court New Orleans: University Press of the South, 2008.

Elliott, Dyan. Proving Woman: Female Spirituality and Inquisitional Culture in the Later Middle Ages. Princeton: Princeton University Press, 2004.

Farriss, Nancy M. Crown and Clergy in Colonial Mexico, 1759-1821): The Crisis of Ecclesiastical Privilege. London: Athlone Press, 1968.

Finke, Laurie A. Feminist Theory, Women's Writing. Ithaca, NY: Cornell University Press, 1992.

Foucault, Michel. The History of Sexuality, vol 1. New York: Pantheon Books, 1978.

Franco, Jean. Plotting Women: Gender and Representation in Mexico. New York: Columbia University Press, 1989.

Glantz, Margo. Sor Juana Inés de la Cruz: ¿Hagiografía o autobiografía? Mexico: Grijalbo-Universidad Autónoma de México, 1995.

Giles, Mary E., ed. Women in the Inquisition: Spain and the New World. Baltimore: John Hopkins University Press, 1999.

Glucklich, Ariel. Sacred Pain: Hurting the Body for the Sake of the Soul. Oxford: Oxford University Press, 2001.

Gonzalbo Aizpuru, Pilar, ed. Las mujeres en la Nueva España: Educación y vida cotidiana. México: El Colegio de México, 1987.

Greenleaf, Richard E. The Mexican Inquisition of the Sixteenth Century. Albuquerque: University of New Mexico Press, 1969. 
Gunnarsdottir, Ellen. Mexican Karismata. The Baroque Vocation of Francisca de los Ángeles, 1674-1744. Lincoln: University of Nebraska Press, 2004.

Haliczer, Stephen. Between Exaltation and Infamy: Female Mystics in the Golden Age of Spain. New York: Oxford University Press, 2002.

Hillman, David and Carlo Mazzio, eds. The Body in Parts: Fantasies of Corporeality in Early Modern Europe. New York: Routledge, 1997.

Holler, Jacqueline. "Escogidas plantas": Nuns and Beatas in Mexico City, 15311601. New York: Columbia University Press, 2005.

Homza, Lu Ann. Religious Authority in the Spanish Renaissance. Baltimore, MD: John Hopkins University Press, 2000.

Ibsen, Kristine. Women's Spiritual Autobiography in Colonial Spanish America. Gainsville: University Press of Florida, 1999.

Israel, J. I. Race, Class and Politics in Colonial Mexico: 1610-1670. London: Oxford University Press, 1975.

Jaffary, Nora. False Mystics and Deviant Orthodoxy in Colonial Mexico. Lincoln: University of Nebraska Press, 2004.

Kavanaugh, Kieran and Otilio Rodriguez, trans. Teresa of Avila. "Life." The Collected Works of St. Teresa of Avila, vols. 1, 2, 3. Washington: Institute of Carmelite Studies, 1976.

Kieckhefer, Richard. Unquiet Souls: Fourteenth Century Saints and Their Religious Milieu. Chicago: University of Chicago Press, 1984.

Kirk, Stephanie L. Convent Life in Colonial Mexico. A Tale of Two Communities. Gainesville: University Press of Florida, 2007.

Lacan, Jacques. Ecrit: A selection. New York: Norton, 1977.

Lavrin, Asunción. Brides of Christ: Conventual Life in Colonial Mexico. Stanford: Stanford University Press, 2008. ed. Sexuality ad Marriage in Colonial Latin America. Lincoln: University of Nebraska Press, 1989.

and Rosalva Loreto López, eds. Diálogos espirituales. Letras Femeninas Hispanoaericanas. Siglos XVI-XIX. Puebla: Universidad de las Américas/Benemérita Universidad Autónima de Puebla, 2006. 
and Rosalva Loreto López, eds. Monjas y beatas. La escritura femenina en la espiritualidad barroca novohispana Siglos XVII y XVIII. Puebla: Universidad de las Américas/Benemérita Universidad Autónima de Puebla, 2002.

Le Goff, Jacques. The Birth of Purgatory. Chicago: University of Chicago Press, 1984.

León, Fr. Luis de. La perfecta casada [1534]. Mexico: Editorial Porrúa, 1970.

Leonard, Irving A. Don Carlos de Sigüenza y Góngora: Un sabio mexicano del siglo XVII. Mexico: Fondo de Cultura Económica, 1984.

Lerner, Gerda. The Creation of Feminist Consciousness: From the Middle Ages to 1870. Oxford: Oxford University Press, 1993.

Lippy, Charles H., Robert Choquette and Stafford Poole. Christianity Comes to the Americas 1492-1776. New York, N.Y.: Paragon House, 1992.

Loreto López, Rosalva. Los conventos femeninos y el mundo urbano de la Puebla de Los Ángeles del siglo XVIII. México: El Colegio de México, 2000.

MacCulloch, Diarmaid. The Reformation. New York: Penguin, 2005.

Makowski, Elizabeth. Canon Law and the Cloistered Women. Periculoso and Its Commentators, 1298 - 1545. Washington, DC: Catholic University Press, 1997.

Maravall, José Antonio. Culture of the Baroque: Analysis of a Historic Structure. Minneapolis: University of Minnesota Press, 1986.

Marquez Rodriguez, Alexis. lo barroco y lo real maravilloso en la obra de Alejo Carpentier. Mexico: Siglo Veintiun Editores, S. A., 1984.

Moraña, Mabel, ed. Mujer y cultura en la Colonia hispanoamericana. Pittsburg: Biblioteca de América, 1996.

Mujica, Barbara. Women Writers of Early Modern Spain: Sophia's Daughter. New Haven: Yale University Press, 2004.

Muriel, Josefina. Conventos de monjas en la Nueva España. México: Editorial Santiago, 1946. México, 1982. 
Myers, Kathleen A. Word from New Spain: The Spiritual Autobiography of Madre María de San José (1656-1719). Liverpool: Liverpool University Press, 1993.

. Neither Saints nor Sinners: Writing the Lives of Women in Spanish America. Oxford: Oxford University Press, 2003.

and Amanda Powell. A Wild Country Out in the

Garden: The Spiritual Journals of a Colonial Mexican Nun. Bloomington: Indiana University Press, 1999.

O'Malley, John W. The First Jesuits. Cambridge: Harvard University Press, 1993. . Trent and All That: Renaming Catholicism in the Early Modern Era. Cambridge, Harvard University Press: 2000.

Ong, Walter. Orality and Literacy: The Technologizing of the Word. New York: Routledge, 2002.

Perry, Mary Elizabeth, and Anne J. Cruz, eds. Cultural Encounters: The Impact of the Inquisition in Spain and the New World. Berkeley and Los Angeles: University Press of California, 1991.

Petroff, Elizabeth A., ed. Medieval Women's Visionary Literature. New York: Oxford University Press, 1986.

Poutrin, Isabelle. Le voile et la plume: autobiographie et sainteté féminine dans l'Espagne moderne (Madrid: Casa de Velázquez, 1995).

Ramos Medina, Manuel, coord. Memoria del II Congreso Internacional del Monacato Femenino en el Imperio EspanPol: Monasterios, beaterios, recogimientos y colegios. Mexico: Condumex, 1995.

Riches, Samantha J.E. and Sarah Salih, eds. Gender and Holiness: Men, women and saints in late medieval Europe. London: Routledge, 2002.

Ross, Kathleen. The Baroque Narrative of Carlos Sigüenza y Góngora: A New World Paradise. New York: Cambridge University Press, 1993.

Sánchez Lora, Luis: Mujeres, conventos y formas de religiosidad barroca. Madrid: Fundación Universitaria Española, 1988.

Scarry, Elaine. The Body in Pain: The Making and Unmaking of the World. New York: Oxford University Press, 1985. 
Schlau, Stacey. Spanish American Women's Use of the Word: Colonial through Contemporary Narratives. Tucson: University of Arizona Press, 2001.

Schons, Dorothy. Algunos parientes de sor Juana Inés de la Cruz. Mexico: Imprenta Mundial, 1935.

Schroeder, Rev. H.J., OP, trans. Canons and Decrees of the Council of Trent. Rockford, Ill.: Tan Books, 1978.

Scott, Joan Wallach. Gender and the Politics of History. New York: Columbia University Press, 1988.

Slade, Carole. Saint Teresa of Avila, Author of a Heroic Life. Berkeley: University of California Press, 1995.

Socolow, Susan Migden. The Women of Colonial Latin America. Cambridge: Cambridge University Press, 2000.

Stern, Steve J. The Secret History of Gender: Women, Men and the Power in Late Colonial Mexico. Chapel Hill: University of North Carolina Press, 1995.

Surtz, Ronald E. Writing Women in Late Medieval and Early Modern Spain: The Mothers of Saint Teresa of Avila. Philadephia: University of Pennsylvania Press, 1995.

Tudela, Elisa Sampson Vera. Colonial Angels: Narratives of Gender and Spirituality In Mexico, 1580-1750. Austin, University of Texas Press, 2000.

Underhill, Evelyn. Mysticism. New York: Doubleday Image Books, 1990.

Vives, Juan Luis. The Education of a Christian Woman: A Sixteenth Century Manual [1538] ed. and trans. Charles Fantazzi. Chicago: University of Chicago Press, 2000 .

Weber, Alison. Teresa of Avila and the Rhetoric of Femininity. Princeton: Princeton University Press, 1990.

,ed. Approaches to Teaching Teresa of Ávila and the Spanish Mystics New York: The Modern Language Association, 2009.

White, Hayden. The Content of the Form: Narrative Discourse and Historical Representation. Baltimore: John Hopkins Press, 1987.

Wiethaus, Ulrike, ed. Maps of Flesh and Light: The Religious Experience of Medieval Women Mystics. Syracuse: Syracuse University Press, 1993. 
Wilson, Katharina M. and Nadia Margolis, eds. Women in the Middle Ages: an Encyclopedia. Westport, Conn.: Greenwood Press, 2004. 


\section{APPENDIX A}

\section{Transcribed Citations}

All punctuation and capitalization has been added. Spelling has been modernized.

1. February 1758 (fol. 5): Yo soy Phelipa de Jesús y esta gracia me concedió en el Baptismo luego en la que me concedió mi madrina de ponerme su nombre claro es que he de ser participante de las penas de Maria de Jesús y de mi S[an]to Phelipe.

June, 1758 (fols. 81-82): No vi a nada sino que me penetraban el alma los quejidos de algunas almas. Me parecía que me llamaban por mi nombre [nubo?] María de Jesús Phelipa .

2. September 1751 (fol.109v): Ya andaba buscando unos libros jocosos y divertibles, procuraba jugar a los naipes, con mayor cuidado todo a quererme quitar aquel cordelejo y tormento interior.

3. February 1751 (fol. 25): Pues como estaba tan cargada de cuadernos y me veía mi corazón tan lleno de diferentes mercedes y también revoluciones que no tenía noticia $\mathrm{V}$ [uestra] $\mathrm{R}$ [everencia] quería abreviar para seguir con quietud mi razón y tener desahogo por lo que le instala a V[uestra] R[everencia] me concediera dar lo atrasado y lo presente. A esto me negaba lo que pedía diciéndome que no convenía hacer eso porque el M[uy] $\mathrm{R}$ [everendo] P[adr]e cura lo determinaba de su manera, en donde me cerró la puerta de este recurso.

June 1751 (fol. 72v): Yo por lo que a mí tocaba, muy contenta me estaba sin escribir porque bien sabe Dios el sacrifico que en eso le hago y lo pensaba a mi favor que era lo pasado dejarlo así y sólo fuera escribiendo lo de presente, esto conocía.

4. August 1751 (fol. 95): Luego me trajo una doctrina de la M[adr]e Agreda señalada en la que le dice mi S[eño]ra: que no se debe inquirir por vía sobrenatural lo que se puede conseguir con diligencia natural.

5. August 1751 (fols. 99-99v): Acabada de comulgar el día diez y nueve y sentía mi corazón esparcido, dilatado ... Me parecía que se me incorporaba el alma en aquel espiritú dulce y amoroso de mi amado y que sóla yo y su magd [majestad] estábamos en este mundo.

6. April 1751 (fol. 54): Así quedé hasta el viernes que mientras cantó la misa el M[uy] $\mathrm{R}$ [everendo] $\mathrm{P}$ [adr]e cura se aumentó el gozo interior de manera que me parecía imposible haber conseguido tantas mercedes.

7. April 1751 (fol. 54v): A los perros no dejaba de poner los ojos en el siglo. Me quería salir de este convento y este pensamiento me sosegaba en las ansias que sentía porque pensaba que mejor fuera vivir entre gentes del siglo desbaratodos como yo que no en parte donde había corazones tan duros que como lo hacían con los animales lo hicieran con las gentes. 
8. June 1751 (fol. 71v-72): Y le doy al S[eño]r especiales gracias de que me concede al darme comunicación con humildes porque me inclino a quererles y mi amor no puedo tener oculto .... y por este motivo quiero a los perros por leales y tener esa condición.

9. July 1751 (83-83v): Cuando empecé a tomar la pluma por nueva obediencia de V[uestra] $\mathrm{R}$ [everencia], y como tenía tantísimos júbilos mi alma de verse tan sujeta a la obediencia, parecía que penetraba hasta el cielo. . . Me puse a escribir con estas ayudas tan de gracia hasta que ya la luz no me dio lugar. Ya había gustado de muy buenas confortaciones y como mis enemigos no había podido fijar nada, aunque habían hecho sus diligencias, siempre me hallaban divertida.

10. April 1751 (54): Como si el R[everendo] [Padr]e cura viera mis confusiones así me habló cogiéndome la cabeza con sus manos y mandándome que no dejara de escribir porque hacía mala obra a los dos que estaban suspensos. Al contacto de sus manos sintió mi alma una grande fortaleza.

11. October 1751 (124v-125): Como no dejó de venir a darme consejo y luz según lo que le escribía, alentándome que me desahogara y pusiera todo lo que me pasaba, me comprimía sensiblemente el corazón porque como me decía V[uestra] $\mathrm{R}$ [everencia] que bien conocía que callaba mucho que lo que escribía. No servía de nada porque todo estaba lleno de temores y dudas en que conocidamente callaba yo. . . Sensiblemente le oya en los oídos no hagas tal no hagas tal y todos lo que dejo dicho me ponía delante en esas voces que me veía atribulada y con la guerra encima disimulando por V[uestra] R[everencia] porque no quería y más con eso que tenía presente hablarle nada y confieso que esa respuesta daba: "No. No callo nada. Lo que puedo manifestar, escribo. No tengo otra cosa y a eso me decía V[uestra] R[everencia]: "Pues, hija tú te haces la burla porque si no dices tus aflicciones, ni lo que te pasa tú sola padeces, porque el mal comunicado si no se quita se alivia."

12. September $1751(107 \mathrm{v}, 108)$ : Abrasaba con alegría como llegué a presencia de $\mathrm{V}$ [uesta] R[everencia] disimulando lo que me esperaba diciéndole que ya era tiempo de que si se ofrecía declarar en los cuadernos lo que me había pasado con Don Pedro. . . . La respuesta de V[uesta] R[everencia] fue decirme, "No, hija. Paremos al confesionario y hablaremos despacio." .. . Pues no me quedaba resquicio de consuelo y que en lugar de consolarme V[uestra] R[everencia] antes más apretaba con sus razones a tirarme a desesperar.

13. January 1751 (fol. 14-14v): No puedo menos que seguir la luz que me encamina porque como en lo que tengo mandado es para el tiempo venidero. . porque cuantas y cuantos leyendo eso cuando llegue el decreto divino se alentarán y vervorizarán unos a otros no teniendo temores.

14. January 1751 (fol. 2): tormenta sentía en todos lo(s) miembros desde la cabeza hasta los pies. Y como cuando estoy de esta suerte no quisiera ni ver gentes ni andar porque no parece sino que cada paso me taladra y trapasa lo más íntimo. . . . Quisiera estarme en este mi retiro pero como me era fuerza haber de estar en el coro que cuando parecía ya se minoraban los quehaceres venían otros que no me podían dispensar el trabajo agregado al otro. 
15. August 1751 (fol. 99v): Me vino a avisar de que ya había hecho todo lo que le había dicho: que el caballero había admitido gustoso la noticia, vinieron juntos, estuvieron conmigo. Supo V[uestra] R[everencia] que estaba necesitada de lo interior; se lo dijo V[uestra] R[everencia]. Y luego, luego me remitió camisa, enaguas y un pañuelo, no dándose por entendido de que $\mathrm{V}$ [uestra] R[everencia] se lo había dicho.

16. August 1751 (fol. 93v-94): Se me junto al que mi M[adr]e se violentara contra mí sólo porque le dije que pagara a todos los acreedores aunque no nos quedara para nosotros nada: que por eso me había yo avergonzado -- esto era porque quería verstirme a mí, pero yo no quería eso. Le puso el demonio vergüenza. Se afligió y formó tal sentimiento que se hizo una historia entre los dos entendible y hasta llegó a saberlo mi M[adr]e Mayordoma, diciéndome unos pesares en su presencia que ya reventaba mi corazón de sentimiento.

17. August 1751 (fol. 98v): "S[eño]r Don Pedro: Que yo no soy nada ni valgo nada. Y como sierva y esclava de V[uestra] M[erce]d, de todas maneras me constituyo, mirando a mi hermanito desde que el S[eño]r me mostró esto como ha señalado ministro suyo. .. Es preciso confiera el negocio porque ha menester consultar pero con tal sigilo que no corra mi ruindad ningún detrimento. Siempre recelando, no por aquí me viniera alguna trampa del demonio, pues bien tenía entendido le pesaba el que yo anduviera en esta solicitud.

18. August 1751 (fol. 99): Dije que a V[uestra] R[everencia] por ser mi P[adr]e le tocaba enseñarle la respuesta, exaltarle, alentarle y ofrecerse a que consultara con $\mathrm{V}$ [uestra] R[everencia] por quitarle de por medio el que fuera con otros, advirtiéndole que sólo con su confesor confiriera y con V[uestra] R[everencia] por ser de su cuenta y por su mano la noticia que recibía esto. Le dije a V[uestra] $\mathrm{R}$ [everencia] me parecía que en lo que a mí me tocaba ya había cumplido en poner en sus manos el negocio que no tenía más que hacer.

19. January 1751 (fol 12v): Me afligía de ver que el M[uy] R[everendo] P[adr]e cura no se daba por entendido de mis penas, sabiendo que no las ignoraba. . .y al contra de lo que el demonio me persuadía, ejecutaba diciendo cuando más contrario me lo ponía, Dios haga un santo al M[uy] R[everendo] P[adr]e cura.

20. January 1751 (fol.10v): "No. No estoy condenada por eso. Por otros pecados puede ser. La hermana no dejó ni ha dejado de comulgar con que ni aún esos cargo tengo."

21. May 1751 (fol. 67): La doctrina [christiana] es el [M]aná de las almas y todo cuanto se busca en ella se halla, sea lo que fuere. Lo tengo experimentado y sin hubiera este ejercicio que necesita soledad, con todo mi corazón en eso sólo me ejercitará enseñando a las chiquitas esta ciencia escondida.

22. June 1751 (76v-77): Me costaba trabajar al doble porque todo se me olvidaba con tal extremo que tenía la cosa delante o en mi mano y eso me hacía hacer del coro al Noviciado tres o cuatro veces y apurarme porque ya ni sabía lo que quería. Me hablaba y no podía atender. Otras me decían: “¡Bestia! Entiende lo que se te dice." Y les decía: "Sí.” Y se reían. 
23. June 1751: (fol. 70): La puse en la elección de su vocación haciéndole presente lo delicado del estado religioso a lo que dobladamente se obligaba porque no estando con la dote ya veía la esclavitud en que estaban las músicas.

24. June 1751 (fol. 70): Esto me ponía reventar porque si le decía algo en defensa de Rosa era ponerlo peor, con que a todo me sujetaba tragando lo que para mi genio es contrararísima ver una sin razón que no sé como estoy gorda porque mi natural es muy intrépido y violento y más en cosas así que cuando me sujeto como en esta ocasión.

25. March 1751 (fol 33): Aunque soy por mi sexo incapaz y muy ignorante, en esta comunicación de mis dos custodios, aprendo mucho y me hallo tan ilustrada que me sirve de recreo el grande trabajo que tengo.

26. August 1751 (fol. 94-94v.): Me es todo trabajoso por mi incapacidad, mi soberbia, amor propio y ninguna paciencia. Y así esto que me dice su Paternidad, lo creo; y conoce muy bien mis incapacidades, pero no está en mi mano la resistencia a esos mosquitos porque aunque sean asi, si aun tiempo pican en diferentes partes del cuerpo, lo llenarán de ronchas. . . Por eso cuando me atribulo mucho, recurro a V[uestra] R[everencia] ya su P[aternida]d que son los que me han de aconsejar.

27. August 1751 (fol. 99v): Soy llevada por mal, no lo niego, pero bienvista siempre el mal es bien para el alma. Y que el amor no puede estar ocioso cuando Dios enciende la llama del afecto a que su Majestad conduce al no tener nada sino todo favorable.

28. November 1751 (fols. 137-137v.): Voy dando esta razón porque vea V[uestra] $\mathrm{R}$ [everencia] que lo que puedo mostrar, lo declaro -- conforme me pasa: la obediencia, no la conozco. Porque como naturalmente soy inclinada a dar gusto a las personas debajo de cuyo dominio estoy, no me hace fuerza el hacer lo que me mandan aunque sea en contra de mi gusto porque lo tengo seguro en obedecer a mis superiores y a cualesquiera personas.

29. November 1751 (fol. 137v.): Yo no hallo nada ni tengo luz de nada especial. Porque esto que digo todo lo cubre mi maldad y no hallo más que Dios se hace la costa en todo.... Me ha escogido entre tantas almas que mucho mejor que yo pudieran servirle de mayor exaltación y gloria.

30. May 1751 (fol. 63v): Me vine a este mi retiro, me desnudé y con el deseo de satisfacer por él, me azoté con cuanto rigor todo el cuerpo. Cargué mi cruz al hombro llorando con todo mi corazón los pecados de esta alma clamando por su remedio a S[eño]r S[a]n Miguel que esto fue día de la Aparición del S[an]to Arcángel.

31. February 1751 (fol. 20, 20v): Lo más que hacía era arrimarme contra la silla y alzar un pie. . y esto me corrían las lágrimas sin sentir de los mismos dolores esto si salían ver y me preguntaban y le echaba la culpa a las muelas. 
32. May 1751 (fol. 64): Los ejercicios me duraron desde las nueve hasta cerca de la una. Tenía el cuidado de que esto no había sido con licencia de V[uestra] $\mathrm{R}$ [everencia], pero no me pude detener y también me acordé de que la tenía general según Dios me inspirara.

33. January 1751 (fol.14): Quería fueran estos ejercicios por espacio de nueve días pero no tuvo fuerzas el bruto por lo que le escribí a V[uestra] R[everencia] dándole razón de como estaba obedecido y lo que sentía mi alma y cuerpo consoladísima de todas manera porque huyeron los demonios.

34. July 1751 (fol. 81): Pero como no podia callar nada le mostraba a [mi Madre] todo cuanto en este conflicto padecía: le decía la culpa como forzada y le mostraba el enfado que me causaba verme a sus pies.

35. January 1751 (fol.14v): Y cuando se recibe de mano ajena la mortificación le es más dulce al espíritu y más meritoria porque entonces en algo se imita a quien [Jesucristo] recibió tanta por nuestros pecados.

36. January 1751 (fol. 15): Haga la prueba y experimentarán el uno al otro tales efectos que verá V[uestra] R[everencia] como llega el tiempo en que conozca muy en lo secreto del corazón lo que tanto ha deseado que es servirle en cosa que sea de su agrado.

37. July 1751 (fol. 87v-88): Resulta que [mi Madre] se molesta, se contrista, se aturde porque piensa y se le radica que si esto poco no puede aguantar como será el purgatorio. De allí en lugar de servirle de aliento le sirve de quedarse metida en confusiones. ... A pocos días se acabó todo porque viéndola tan atormentada y que era motivo de atribularla, suspendí el no hacerlo y privarme del alivio.... Su respuesta continua era llorar y decirme que nada. Luego que la veía de esta suerte la procuraba alentar y consolar y no proseguir como esto me atormentaba más. ... Acudió al S[eño]r que ponerle a V[uestra] R[everencia] en el corazón que suspendiéramos nuestros ejercicios aún sabiendo de mi parte nada me sirvió de mucho desahogo.

38. October 1751 (fol. 131): V[uestra] R[everencia] me decía más no sé el como y esto me ponía en sosiego lo que al sentido me causaba angustia y me oprimía... "Hija: escribe como ahora. Que así me hago cargo de tus aflicciones. Deja temores. Antes mejor que me pongas todo lo que sintieres con eso. Lo llevo todo al S[an]to Tribunal." Que al oír esto le dije a V[uestra] R[everencia]: "Pues, vaya. Si ha de ser así, lo escribiré todo que V[uestra] R[everencia] me dijo." "Sí, hija. Eso quiero."

39. July 1751 (fol. 86-86v): “Tú tienes la culpa de verte en ese batallón. La pulmonía que te diere no la contarás y no te escaparás de purgatorio porque te quitas la salud. ¡Mírate! Echa esclava de tu mismo gusto, escribiendo azotada como están en el obraje los esclavos, por tonta pudiendo gozar de tu vida y no estar. ¡Dále! ¡Quédate fuera! ¿De qué pierdes el tiempo, tu alma, tu crédito? Porque si sale a luz tanto desatino te verás en una afrenta se te espera pasar muchas vergüenza por escritora de mentiras que hay en ti bueno. Todo es para que te chiflan. ¿No 
ves que Dios es digno de toda reverencia y que tú eres una mujercilla, puerca de mala muerte? ¿Quién te ha dicho que este S[eño]r que no se deja ver de nosotros por su grandeza había de ser tu esposo? Anda y no creas ilusiones fantásticas que verdaderamente yo te hablo con su licencia.... Esos hombres gustan de leer desatinos y su divertimiento es el hacerte escribir. Bien conocen que todo es falso pero por ver hasta cuando te precipitas, están haciendo bien la cita. Los vieras como les sirve de entretenimiento. Ellos te engañan a ti y tú a ellos. Y así se van pasando la vida en continua ociosidad. Acuérdate de esto que te digo: Tú verás como cuando más descuidada estás se viene una resulta en que dudan de todo. Entonces te acordarás de mí; entonces maldecirás tu mal gusto y sentirás obedecer a quien no debes."

40. March 1751 (39v, 40): "Ningún santo fue hablador, callados sus voces hacían oración, se despedazaban los cuerpos a penitencias, no dormían en cama sino en el suelo con grandes tormentos, no comían ni tenían las libertades que tú. . ¿ ¿Qué haces al presente fingiendo enfermedades, escribiendo mentiras, durmiendo y comiendo como todos los demás? Vuelve mujer en tu acuerdo. Sal de tanto error. Mira si estas razones te convenzan. Pues no correspondes si es verdad lo que escribes. ¿Cómo no muestras las hazañas famosas del amor? . . Pues no pecas de ignorancia. Ya de aquí adelante todo lo que escribieres es falso, engañoso y si esos idiotas no conocen el hierro, yo se los pondré claro para que ni unos ni otros caminen tan en manos de su ignorancia, porque no solo tú pereces sino que de encuentro te llevas a otros."

41. October 1751 (fol. 132, 132v): "Te han quitado las mortificaciones y ejercicios que hacíais tú y esa otra porque es cosa indigna y muy aborrecible a Dios que os castiguéis de esa manera. Quebrantáis el voto de castidad y si en vosotras es malo, más reprobados están los Ministros del S[eño]r porque a esos les toca enseñar pureza y decencia en los mortificaciones. Tú deshonestamente te pones en cueros. No te avergüenzas ni tienes respeto a Dios que todo lo vee ni a sus S[an]tos ni a los demonios."... "Díme qué gusto le hayas a maltrate y atormentarte para que quieras que todos hagan lo mismo.

42. March 1751 (fol. 32v, 33): Porque estas conversaciones [sermones] según me parece o la experiencia me enseña no son como las de por acá que por buenas que sean cansan y más a quien no entiende lo que oye aunque oiga una conversación muy buena. ... Así que aunque soy por mi sexo incapaz y muy ignorante en esta comunicación de mis dos custodios aprendo mucho y me hallo tan ilustrada que me sirve de recreo al grande trabajo que tengo en hacer esto. . fue mi total remedio el estar en esto mi retiro ejercitada en escribir.

43. February 1751 (fol. 27v-28): "Sabed que aunque vos sola gastarais todo el papel del mundo en escribir lo que se os manda, no tenéis en eso que os aflija. . .pues con el sudor de vuestro rostro ganáis el corazón de muchas almas. . .escribiendo su majestad en lo blanco y puro de vuestra alma y voz trasladando en el papel lo que es muy de su agrado ejercitando en eso mismo los votos religiosos de obediencia, pobreza, castidad y clausura.

44. June 1751 (fols. 72v, 73, 73v): Me mostró estar en mi alma adornado de muy ricas vestiduras y mis custodios por orden de su Rey soberano me vistieron de la 
misma tela. . . . Me veía toda la vestidura sembrada de formas y estas que resplandecían con más claridad que el sol material reverbera en una vidriera. . . En aquel trono donde me ponía en las manos una cadena de donde pendían otras que entre los dos estirábamos, veía que venían pendientes muchos corazones y en ellos respandeciendo el S[an]tísimo sacramento ... Me dijo: "Mira, estos corazones son de bárbaros. Unos estos son de pecadores y estos son de justos que secretamente están recibiendo unos socorro en sus necesidades, otros alivio en sus tentaciones y otros el feliz desahogo de sus conciencias atribuladas ... pero mientras estás con el habito tosco de la carne te toca mirar por los tuyos. Esto es no olvidarte de los mortales, de los infieles y bárbaras naciones: que como tú cuides de los míos, yo cuidaré de los tuyos.

45. March 1751 (fol. 33v): "Eso es lo que yo quisiera de todas mis criaturas que se unieran a mi voluntad llevándome por delante por guía en lo que es de mi agrado: no temieran ni la muerte ni angustia ni persecución ni al demonio ni dolor ni tentación, porque en seguimiento de mis pisadas toda carga es ligera, todo dolor se alivia, el tormento cesa, la tempestad se suspende.

46. May 1751 (fols. 63v): Le protesté no apartarme de ellos sino me concedía el perdón que le pedía. Apiadado me dijo: "Te prometo lo que me pides y para que veas como ya está asegurado dame tu corazón. Y tomándolo graciosamente escribió su nombre mojando con la sangre de su costado el instrumento, puso 'Jesús de este corazón.' No contenta con esto le pedí lo hiciera en el corazón del enfermo y me dijo: "Ya está escrito en el libro de los bienaventurados. Ten seguro que eres su Madrina y no le dejaré que perezca."

47. May 1751 (fol. 59v): "Yo amo a las esposas de mi hijo y para que veas lo fiel que soy contigo querida del muy alto y omnipotente brazo te vengo a consolar y esforzar a lo que te resta."

48. May 1751 (61): "Pues yo y todos tus devotos estamos a la mira de que el Señor sea exaltado y conocido según la pretensión del amor que te tiene. La gracia que hoy por mi intercesión te ha concedido veas no es para que la olvides sino para que te esfuerces en todos los demás trabajos que te vinieran."

49. May $1751(61 v)$ : "Yo las daré por ti a mi eterno padre pues eras poseedora de los [tratos?] y merecimientos de Jesús, María y José”. . . . No entendí esto cómo sucedió sino que me daba a entender estaba mi muerte cerca y que estos trabajos eran los últimos con lo que me consolé, no por no ha de ser sino porque me vea tan distinta de una manera a otra que lo que en semejantes mercedes recibo. 


\section{APPENDIX B}

Names Mentioned in the Text

Father Gaspar (visiting preacher), January, fol. 10v.

Father Fernando Friseros (disagreement with him), January, fol 17v.

Father Francisco Arias (her first confessor), March, 40.

Mother María Gertrudis (ill), June, fol. 68-68v.

Father Joseph, June, 69v.; also Most Reverend Father Joseph, September,112v. (the Chaplain?)

Father Anito Antonio, September, 112; also Antonio Joseph Villerias, October, 132 (her confessor?)

Mother Maria Theresa (prayed for her), October, 132.

Mother Sister Ignacia, (prayed for her) October, 139.

Señora Ana Latorizes, (prayed for her) October, 139. 